University of Louisville

ThinkIR: The University of Louisville's Institutional Repository

Electronic Theses and Dissertations

1942

\title{
England, Germany and the Portuguese colonies, 1898-1914.
}

Paul R. Kneisel 1917-2004

University of Louisville

Follow this and additional works at: https://ir.library.louisville.edu/etd

Part of the Diplomatic History Commons, and the European History Commons

\section{Recommended Citation}

Kneisel, Paul R. 1917-2004, "England, Germany and the Portuguese colonies, 1898-1914." (1942).

Electronic Theses and Dissertations. Paper 1815.

https://doi.org/10.18297/etd/1815

This Master's Thesis is brought to you for free and open access by ThinkIR: The University of Louisville's Institutional Repository. It has been accepted for inclusion in Electronic Theses and Dissertations by an authorized administrator of ThinkIR: The University of Louisville's Institutional Repository. This title appears here courtesy of the author, who has retained all other copyrights. For more information, please contact thinkir@louisville.edu. 


\title{
UII VIRSITY OF IOUISVIILF
}

RNGLAID, GERMANY AND THE PORTUGUESE COLONIES 1898-1914

\author{
A Dissertation \\ sabmitted to the Faculty \\ Of the Graduate School of the University of Ionisville \\ In Partial Fulfiliment of the \\ Requiremente for the Degree \\ of Master of Arts
}

Departmont of History

by

Paul R. Knelael

Year

1942 
RAME OF STUDEIT:

TITIE OF THESIS: FNGTAND, GRRMANY AND THB PORTUGUESE COLONIBS 1898-1914

APPROVED BI $\triangle$ RRADIIG COMAMTILEE COMPOSID OF THE FOLIOW ING MEMBERS :

HAME OF DIRECTOR:

DA TI: 
BNGIAID, GERMANY AND TEF PORTUGUESE COLONIES 1898-1914 


\section{ACKNOWL EDGME HIS}

The completion of this thesis would have been extremely difficult if not impossible had I not received generous help from others interested In historioel researoh. I wish to thank an old friend Charlie $Y$. Dunean and a new friend, Cammililo Mallie--whorerer he may now be--for the aid they gave mo in translating lengthy passages from Frenoh and Portuguese. I l1kewise thank my oritic and advisor on this thesis, Dr. J. M. Read, for the help and encouragement he gave mo. Aoinowledgmente could not be oomplete without an expression of appreciation to the staffs of the Iibraries of the University of Louisville and the University of Chicago for their patienoe and holp. Special thanks is offered to the Portuguese Imbersy for the coneiderate efforts it expended in my behalf.

Paul R. Bnolsol

July 30,1942 
PABLE OF CONTEMPS

PAES

TOREMORD . . . . . . . . . . . . . . v

CHAP TRER

I. THE "ATCIEHW" PORTUGUESE-ENGL TBH

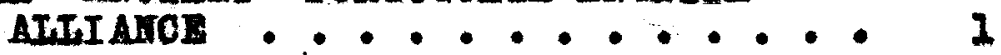

II. BIGLAND, GRPMATY AND THE ITTRRHATIONAT

SCEIE IN $2898 . . . . . . . . .28$

III. SIRPS TOEARD ANGO-GRRMAN COLOHIAI

AGRRGMREIT ............. 58

IV. THE ANGLO-GRRMAN MRFATY OF 1898 . . TE

T. THE AIGLO-PORTUGUESE TREATY OF 1899

OR THE SO-CALLED "WIMDSOR TREATY" . 101

VI. RPILOGUS-1912-1914 . . . . . . 124

VII. CONCLUSIONB--WHO PLID THE PIPER . • 139

BIBLIOGRAPHY ............. 250

APPENDIXES ................ 154

A. Anglo-German Conrention of $1898 \ldots$. I54

B. Secret Convention Appended to AngloGerman Convention of 1898 .... 157

c. Secret rote Bxplaining tho Intention of the Two Contentions Conoluded between Germany and Ingland 1898. - 169

D. Ang10-Portuguese Declaration of 1899. 161

E. Ang10-German Convention of 1913 . . 168 


\section{APPENDIXRs (oont.)}

F. Map IIlustrating the Partition of Portugraeso Colonios in Aocordance With Anglo-German Convention of 1898

G. Map IIluetrating the Partition of Portagnese Colonles in Aceordance with Anglo-berman Contention of 1913 
PORENORD 
FOREWORD

of the vast mosalc of alliances, goorot treaties and eoonomic rivalry that preceded the World War, historical research has widely neglected that section involving the nogotiations of Germany and England on the possibility of the ultimate partition of the Portuguese colonies between themselves. These negotiations cover much of that poriod before the first World War during whioh the alliance systems were consummated. Examination of these negotiations gives som insight into the labyrinthine tunnels of secret treaties, alliances, and counter-alliances. Such an examination not only shows how such stupld diplomacy works but also serves as an excellent reflector by whioh one can eve how imperialism and balance of power becamo motivations for the various alignments that did so much to make modern history what it is. Hence, it can be sald that the Portuguese negotiations offer an interesting study not only for their inherent historical value but also for the illumination they obliquely cost on the genesis of the disastrous alliance system and 1ts natural result--the World War.

The negotiations themselves that occurred 
between Germany and Englend beoause of the colonies of England's age-old ally, Portugal, fall into tro main divisions. The first division embraces an intrloate series of diplomatio maneurers just prior to the Boor War, a series of maneuvers that had considerable importence in determining the complexi on of that war. The second series involving the Portuguese colonies occurred approximately two years prior to the World War. The seoond development was in reality an outgrowth of the first, which had become dormant after Fngland refused to make an immodiate division of Portuguese colonies possible. The second period of negotiation was began more as a mans of finding some grounds on which to establish the beginning of a better understanding between mutually hostile Germang and Bngland than simply as a mons of inoreasing the colonial domaing of the respective negotiatora. The ploode has a rather sordid character because Portugal, a sorereign state, was not officially consulted during the negotiations, nor was Portugal informed of the complete contents of the treatieg that resulted from these negotiations. AI though more or 108 s forced by the pressure of erents and German diplomaey to work with Germany at 
this ante-mortem dissection of the Portuguese Empire, England's particlpation was particularly ombarrassing to her. It was embarrassing beoause Fingland and Portugal had been constant allios for over half a millonium. The manner in which Englend resolved the dilemma of keopling an old friend (Portugal) at the same time she was supposedig paying tribute with her friend's possessions to a possible onemy (Germany) fully oognizant of his potentiality provides an interesting problem of research.

In order to show the ealient features of the problem, this paper will endearor to accomplish the following: (1) give a comprehonsite background of Anglo-Portuguese relations from the inception of the old friendship between those two countries to the end of the Nineteenth Century, (2) give a background of the international situation that dictated Ingland's diplomatic negotiating with Germany for the possible disposel of Portuguese possessions, (3) gire an account of the negotiations, (4) analyze the motivations, (5) analyze the outcome, and (6) attempt to show the impossibility of secret elliances besed on oelfigh fears.

Although a conscientious offort was made for 
aocuracy and objectivity in this research, som hypothecation was necessary to explain why Fngland agreed to discuss the possibility of diriding her friend's empire and to explain why the agreements relative to the division of the empire never materialized. If the writer appears to tend somewhat toward partiality and conjecture, he begs that the color of events in the international scene at the time of this writing be accepted as a partial exouse.

Sfter the first reforence to the Britigh Doouments on the Origin of the Wer and Die Grosse Politik der Burope1sohen Kabinette in this thosis they will be respoctively referred to as B. $D$. and G.P.

No apecific maps illustrating the territorial distribution set forth by the treatios were available for the writing of this thesis. The data on the maps appoaring in this tho 81 o wore as gimilated from the text of the treatios themelves. The information was verified as well as possible by comparison with generel maps of Africa. Good coples of such maps appear in the following atlases: 
Hammond' 8 Hew Forld Atlag, Doubloday Doran, Ine., Garden CIty, New York, 1939

The Matthows-Northrup New International

AtIas, BIue RIbbon Books, Inc., New York

Any general atlas could be used, however, for verification. 


\section{CHAPMER I}

\section{THE "ANCIENT" PORTUGUESE-ENGLISH ALLIANCE}


THE "ANCIENT" PORTUGUESE-ENGLISH ALLIAITCE ${ }^{1}$

\author{
"Bngland does not make alliances-- \\ she grants them." \\ - Lord Cranborno, son of Lord Saliabury \\ Near the close of the Middlo Ages--1578 to
}

be precise--a treaty was concluded between Bngland' House of Iancaster and Portugal's House of Avis. 2 This treaty was to be the predecossor of a rast and uninterrupted series of treatios binding these two kingdoms into an alliance that became by far the oldest existing alliance of the world. 3 In fact, if one were to be exact, the seeds of this understanding that 18 so deoply rooted in modern history were already sown during the Crusades, when the English and Portuguese establishod the friendahip that was to grow into this most permanent of all alliances. 4 With but few

I. The word "Anclent" 18 uged here dosplto the fact that the treatien were coneluded in modieral rather than ancient timos because the diplomatio documente refer to them as the ancient treatios, c.f. Britioh Documents on the Origing of the Worid War. V01. I, 108. 92, 93.

2. British Parliamentary Acoounts and Papers 1899, CIX TC9088), pp. 6811.

3. Jones, Guernsey, "Beginnings of the 01dest Furopean Alliance: Bngland and Portugal," American Historical Assoolation Report for 1916. I, 407.

$$
\text { 4. Ibid., p. } 407 \text {. }
$$


alterations the relations between Ingland and Portugal have been essentialiy the same for almost three centuries, unshaken by wars and revolution involving elther or both states. Truly this is a phenomenon of extraordinary rarity in international relations. It first consideration it might eren geem queer, beoause of the lack of common interests and similarity of race, but alliances are not built upon community or race, religion, or ideals, to say nothing of sentiment or affection, but upon community of fears. 1 England and Portugal have never lacked common enemies.

An examination of the content of this ancient treaty and its successors provides ample proof of commitmonts that England made to Portugal and vioe versa. These oreated a unique and rather embarrassing diplomatic situation for England when Germany undertook to negotiate with her for Portugal's colonies during the jears 1898-1914.

The Treaty of 1373, conoluded just four yeare before the death of Edward II, came as a result of the Hundred Years War, which involved by this time, not only France and England, but also Castile. Hence, it 
was decidedig benefioial for Ingland to enlist the aid of the Portuguese. The treaty gave immodate aid to England, but pat restraints on her in sabsequent dealings relative to Portugal. The following artioles from the treaty themelves explain these regtrainte:

TREATY SIGNED AT LONDON, JUNE 16, 1373

\section{Art1010 I}

In the first place, we settle and corenent that there shall bo from this day forward betwoen our above sald Lord Edward, King of England and France, and Lord Ferdinand, King of Portugal and Algarve, and the Lady Floanor, Queen and his consort, the ir successors in tho aforesald Kingdoms :- and thoir reelms, lands, dominions, provinces - : true, falthful, constant, mutual and porpetual [friondship] Theg shall hencoforth rociprocally bo friends to friends and onemies to onemies and shall arsist, maintain, and uphold each other matually by sea and by land against all men that may live or die, of whatever dignity, tation, rank or condition fhat may be and against thoir realms and domintons. I

They shall strive for peace, as much as in them lies, and personal safety, security, interest and honor, and the harmlessness, conserration and restitution of their rights, property, oliects and Iriends, wheresoever they be.

They shall overywhere faithfully prevent the hurts and injuries, disgrace, or baseness which they kmow or which one party knows to be at any future time intended or contemplated againgt the other party, and shall provide remedies for them; - - without reserve, and fully inform, forewarn and successfully counsel the other party against whom such things are moditating... - 


\section{Articlo II}

Also, neither party shall form friondships with the enemies, rivals or persecutors of the other party or knowingly himself or through others advise, ald or favour the enemies, rivals, or persecutors of the other party, to his detriment, hurt, or prejudice; or gratify them in any way, receive them into his kingdom or lands, or knowingly suffer them to be gratified, recelved, counterbalanoed, or harboured, either publicly or privately under any specious excuses, contrivances or pretexts . .

Also, if the kingdoms, lands, dominions, or places of the other party should happen to be infested, oppressed or invaded by sea or by land, by enemies, [ete], or if any of these... prepare in any manner or appear... anxious to infest or oppress. - [aid shall be given] .1

Over five centuries before 1898 mgland had already bound herself to preserve Portugal's dominions, strive for the conservation of Portuguese rights and property, prevent everywhere injuries and disgrace which she knew were even contemplated against her ally, maintain straightforth communication to Portugal of any information that involved the safety of Portugal and refuse to give comfort to the rivals of portugal. of course, at the time of the signing of the treaty Fngland received much in return for such self-denying limitations. Portugal acted as a bulwark against her continental rivals.

Thirteen years later in 1386 the clauses of the

1. Britigh Parliamentary Accounts and Papers, 10c. cit., pp. 67-69. 
1373 Treaty were re-emphasized in a new treaty executed at Hindsor. Evidence of this can be especially noted in Clause VII.

\author{
TREATY SIGNED AT WINDSOR, MAY 9, 1386 \\ Article VII
}

Fur ther it is agreed that if either of the aforesald parties can learn, discover, or antiolpate any injury, contumely or disadrantage to have beon planned or moditated against the other party, on sea or land, menifestly or privately, he shall prevent it as much as in him lies, as though he were desirous of preventing the injury and contumely intended to his own interest and shall endeavor by all means in his power, that such design, with all the partionlare connected with it may be brought to the not10e of the other party against which it is so intendod, and erery artifico, deceit, and invention shall be abstained from.1

Between 1386 and 1642 there was an intermission of treaty making; nevertheless good relations were maintained because the two powers never seemed to be Without common onemies. Then, too, the growing influence of the commercial classes in an inoreasingly powerful English government made inevitable the continuance of the adrantages that could be had from judiclously manipulating this willing pawn.2

In 1642 a treaty was concluded between the English House of Stuart and Portuguese House of Ioc. cit., $\frac{\text { Britioh }}{\mathrm{pp} \cdot 69-70 \text {. }}$

2. Jones, 100. 01t., pp. 407-8. 
Braganza which gave to the English merchante in portugal a reasonable amount of religious toleration, protection from financial losses resultant from the Inquisition plus extra-territoriality and immunity from Portuguese law.l In addition to these valuablo concessions the oontracting powers reiterated their previous doolaration of mutaal trust and assistance when they guaranteed to each other in Article I of the Treaty signed at Iondon, January 29, 1642 that, - Ne1ther of the sald most renowned Kings, their heirs and suceessor by himself or any other, sall do or attempt against each other or their Kingdoms by land or by sea nor shall they consent or adhere unto any war counsel, or Treaty in prejudice of the other.2

For a time it seemed that the Puritan Revolution would destroy the understanding between Catholic and Pro-Stuart Portugel and the now more or $108 \mathrm{~s}$ Protestant England. In fact Portugal was the only power to espouse orertly the stuart cause. 3 Portugal had always beon frienaly to the Stuarts. She afforded Charles I access to the rest of Europe by allowing her ambassadors and diplomatic offices to be used for

1. Britigh Parliamentary Accounts and Paperg, 100. o1t., pp. 69-70.

$$
\begin{aligned}
& \text { 2. Ibla., p. } 71 . \\
& \text { 3. Jones, loc. cit., p. } 411 \text {. }
\end{aligned}
$$


commanication and even for the transportation of money and ammunition. 1 Such action naturally brought down on Portagal's head the wrath of the avenging Republic and postponed considerably (26 years) the inevitable final form of the AngloPortuguese Allanoe. In fact, for juat a short time there was a state of war between Portugal and the Protectorate when the Royal "Plratea" Maurice and Rupert took refuge in the Tagus River. Cromwell blookaded Portugal. Klng John IV rotallated by deolaring war. However, he was powerless to do wore than imprison English merchants and sequestrate property. So when the Republioan victory of Duabar Indicated the real strongth of England, John sued for peace, which Gromell agreed to by exeouting another treaty in 1654. This treaty granted Fngland a considerable indemaity and added to the meroantilIstic concessions she had already secured.2 After this treaty was olgned Fnglishmen shared equal privileges with the Portuguese in the Portuguese colonies. It also reomphasized and repeated what had boen guaranteed before:

$$
\begin{aligned}
& \text { 1. Jones, I0c. c1t., pp. 409-410. } \\
& \text { 2. Ib1d., p. } 411 \text {. }
\end{aligned}
$$


It 18 also agreed and conoluded that no other league or confederacy whatsoever made or to be made by the most Serene Iords, the Protootor of Bngland and the King of Portugal, with any other princes or republios whatsoever shall derogate from the present treaty of peace and alliance, but that the peace and confederags ghall be kept ontire and always in full force.I

Even more than the Treaty of 1642 the agreement of 1654 was regarded a a charter of liberties for Inglish in Portugal. 2 It is interesting to observe that although Portugal was the only nation to oppose the Republio openly it was also the first to send a credited ambarador to the "Parliament and Commonwealth of England, "3 So, desplte sentiment, Portugel was more interested in England and not English governments. Although the relations between the two countries during the Puritan interlude were fraught with tension, the relations agaln became reciprooally helpful and friendly. As early as 1660, Portugal was obliged to call upon the despised republio for aid against her enemiea. A treaty with the usual Anglo-Portuguese assurances was conoluded. It wes about to go into effect when the Restoration dissolved the Commonwealth. loc. oit. $\frac{\text { Britigh }}{\text { p. } 11 .}$

8. Jones, 100. c1t., p. 413.

3. Ibid., p. 412 . 
When Charles II returned to England he had intended to reverse the entire foreign poliog of Cromwell. However, his connections with France and negotiations for the marriage with Catherine of Braganza by his chief minister, Clarendon, soon postalated a reversal of his original intentions. The marriage of the two dynasties gave the penultimate touch to the alliance. It was not a suddon decision, for a proposal for marrlage was made in 1644. ${ }^{2}$ It had long been a cherished wigh of portugal's John IV.3 The matter was again disousBed fust after the execution of Charles I. Charles II was found to be sympathetic. Throughout the Puritan crisis the Royal House of Braganza had extended aid and sympathy to the dispossessed occupants of the House of Stuart. When Cherles returned to Fngland Wifoless, he provided in himself the keystone of Bnglish foreign poliog which was in truth merely a corollary of that of Ionis XIV.4 Daring his exile

1. Jones, I0c. Git., p. 413.
2. Ibid., pp. $409-410$.
3. Ward, A. W. and Gooch, G. P. The Cambridge
History of Britioh Foraign Polior, I, i6.
4. Green, John Richard, History of the Englioh People, III, 23618 . 
Charles was obliged to depend upon the varying hospitality of Iouis' K1ngdom. So to him a certain amount of gratitude was due. Howover, Charles did not fall in line with Iouis so much out of gratitude as he did bocanse he know that only by the ald of Louls would he be able to realize his aims. He knew that Louls was designing to roduce Spain to as noar a state of rasealage ar possiblo and that Ioula needed Bnglish aupport to make his hegemony complete. By marrying himaelf to Portugal, an ally of France and foe of Spain, as he had his sister, Henrietta, to the Dake of Orleans, Charles allgned himself, though not formally but noverthelese, definitely, with France. Of copree, Charles reoelved somothing in return for the marriage conveniently arranged by his loyal Clarendon. He recelved the subsidios of Iouls which made poseible his independence from Parliament and luxurlous and profligat life. Horover, Fngland as a nation, too, recelved considerable material returns, not from Louls, but from Portugal, which helped more than a little in laying the foundatione for the domination of the Mediterranean and India.l The English roceived a dowry of half a

$$
\text { 1. Jonob, 100.01t., p. } 419 \text {. }
$$


militon pounds--fabalous in those days--the fortress of Tangier in the Mediterranean, the trading conter of Bombay, India, and political pledges of religion toleration for all Englishmen throughout the Portuguese Fimpire..$^{1}$ At first this arrangement was distasteful to the English poople as a whole, for it came at the same time that charles arranged for the a1sposal of Dunkirk to Louis XIV. 2 The peoplo did not relish trading hard-won Dunk1rk for distant Tangier, nor did they I1ke the growing power of the Sun Kins whose Bourbon Dynasty was beginning to be as much of a specter to thom as the now waning House of Hepaburg had once been. 3

Hevertheless, by sealing this bargain, since ald to Portugal was a steady French poliog, Fngland ranged herself on the side of France as a foo of Spain and as such contributed much to the downfall of hor former rival and persecutor. 4 With Engligh and French support Portugal was able to insure for all time her independence from Spain for which she had

1. Green. op. cit.. p. 23\%.

2. Macaulay, Thoma Babington, The History of England from the Aocession of James II. I, IM.

3. Ibid., p. 179 .

4. Green, 오. itt., p. $23 \%$. 
boon struggling for sixty years. ${ }^{1}$ so just as Spain reached her pinnacle of greatneas in Portugal, she started there, too, her downfall. 2 as evente subsequently proved, this downfall was continualig alded and abetted thenceforth by the meintenance of the Anglo-Portuguese Alliances.

There still another factor in the conclusion of this alliance. That 1\%, the mercantilistic Clarendon was extremely eager and energetlo in inserting commerolal clauses in the wedding treaty, in an attempt to make the marriage to the Catholic Infanta more palatable for meroantiliatio and Protestant Fngland. 3

This union then, of Charles and the Infanta of Portugal not onig allgned Charles with Louia but was open admission that Cromeli's succossful forelgn policy was to be resumed. So despite the Puritan restoration interlude and comio opera Anglo-Portuguese war of 1642, there was no roal alteratiog in the relations of Portugal and ingland."

The marriage was formally sealed by treaty on June 23, 1661 at Whitehall. The first article and secret article of this treaty are interesting because

1. Jonos, 10o. c1t.. pp. 408-9.

2. Green, op. it., p. 237.

3. Jones, 10c. o1t., p. 415.

4. Ward and Gooch, op. cit., p. 22. 
they epecifically bind the signers to ablde by all previous treaties and to protect all conquests of both from all enemies, both present and future.

\section{Articlo I}

That all Treaties made botween Great Britain and Portugal since 1641 until this very time chall be ratified and confirmod in all points and to all intents, and shall recelve as full force and ratification by this treaty as if the were herein particularly mentioned and inserted word by word.

\section{Socrot Articles}

H1s Majesty of Great Britain in regard of the great advantages and increase of dominion he hath parchased by the above mentioned treaty of marriage shall promise and obligo himself as by this present article he doth to defend and protect all conquests or colonies belonging to the Crown of Portugal against all his enemies as well future as present.1

From this time on the arrangements between

Portugal and Fingland remained extraordinarily constant and were never sabject to change--merely re-emphasio of the original theme--that is, with the exception in the years 1898-1914 which 18 the raison d'otre of this discussion.

If some euthorities neglect or refuse to consider the oarlier foundation of the "Oldest Alliance," none deny that 1661 marks the beginning of this rolationship. Even this dato gives it amplo claim

\footnotetext{
1. Brit1gh Parliamentary 1000unts and Papers, 100. c1t., p. T2.
} 
for the most durable of all understandings--over two hundred and fifty years.

The remaining treatios that were concluded In subsequent years comprise a mere catalogue of reassurances--England's rise to world loadership bears witness of this point throughout.

During the Far of Spanish Secession, Portugal, true to her obligations, adhered to England and bocame a member of the Grand Allianco. 1 To bolster and clarify their relations the allies reaffirmed their intentions toward each other by another treaty, which roads in part as follows:

TREATY SIGNED AT LISBON, MAY 16, 1703

$$
\text { Artiolo I }
$$

All former treaties between the above sald powers (Ingland and Portugal) are hereby approved and confirmed and ratified and ordered to be exactly and faitheully observed exoept insofar as by the present treaty is otherwise provided and ostablishod.?

At the Peace of Utrecht after this war England was instrumental in securing concessions for I1sbon. 3

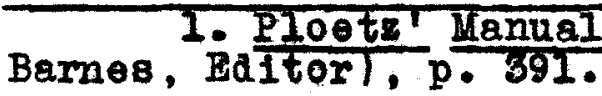

2. Britioh Parliamentary Accounts and Papers, 100. cit., p. 76 :

3. Ward and Gooch, op. cit., p. 54. 
During the Seven Yoars Mar Portugal was invaded by Spain because she refused to end all correspondence and commerce with England. 1 However, by supplementing the national resources of Portugal, England soon offset the effects of the invasion.2 During our American Revolution, Portugal was briefly at war with Spain, Amorica's ally.3

The Portuguese government remained oteadest to Ingland during tho Napoleonic atruggles even when the homeland was taken orex by the Empire of Franoe. In 1807 Portugel was the only country whose ports were excluded from the regtrictions of the orders in Counc11. Later in the same year whon Franoe mored in on Portugal, the Britioh persuaded the Portuguese government to floe from the homoland to Brazil rather then capitulate to Napoleon's demands by eron 60 muoh as a token war on England." The Britioh recelvod permission to use the Ports of Madeira and the Portuguese Fleet.5
1. Ward and Gooch, op. oit., p. 121.
2. Ibid., p. 123.
3. Ibld., p. 166.
4. Ib1d., p. 365.
5. Ib1d., p. 365. 
There was a treaty of Rio de Janeire, signed betwe on Fngland and the Portugaese gorernment in exile, February 19, 1810 to fit the peculiarities of the Napoleonio situation. 1 This treaty was abrogated in 1810 whon a new one was instituted whioh again put the Anglo-Portuguese relations in the1r customery place. Article III explains this entire situation:

The Treaty of Alliance conoluded at Rio de Janelio on the 19th of February, 1810, being founded on circumstances of a temporary nature, which have happily ceased to exist, the sald treaty is sald to be rold in all parts and of no offeot, Tithout prejudice to the Ancient Treaties of Alliance, Friendship and Guaranteo which horeby renewed by the High Contracting Powers and acknowledged to be in full force and effoct. 2

After the Napoleonic furor, England sank into comfortable and "splondid isolation." In fact, for a period of more than fifty years she had no permanent aliy, except little Portugal.

In 1873 when there were republican agitations in spain for an annexation of Portugal to spain, England stood ap for Portugal by informing the spaniah Minister that she would brook no external interference 100. cit. $\frac{119}{\text { p. } 19}$

1. Brit1gh Parliamentary Accounts and Paperg, 2. Ibid., p. 79 . 
in the affairs of hor ally. 1

In 1875 Portugal's colonial possessions in the vicinity of Delagoa Bay in Mozambique, one of the colonies involred in the Germen negotiations, offered specific ground for negotiation between Fngland and her old ally. 2 The Bay itself had been the object of numerous counter conquest claims by Holland, England, Portugal and oren Austria; although Portugal claimed it first by right of discovery. As late as 1861 the British ship Narcissus raised the Britioh flag over the territory. Portugal protested but host1lities did not derelop between these two contenders and friends of convenienoe. Instead it was finally decided to allow Marshal MacMahon, President of France, to act as arbitrator. 3 Evidently, $F_{n}$ gland was not too certain of her claims because the Brition minister to Iisbon requested in a note to Portuguese Minister of Forelgn Affairs that although a decision had not got been reachod by Marshal

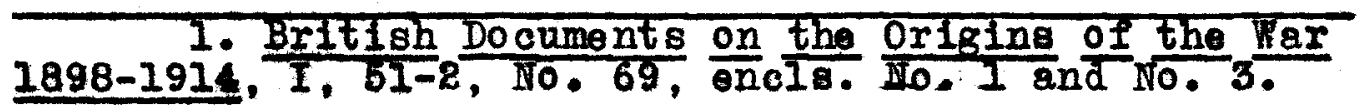

2. Bixler, Raymond, Anglo-German Imperialiom in South Afriog 1880-1900, pp. 104-5.

3. British and Forelgn State Paperg, 1878-7z, IXIII, 1045fI. (cited by BIxIer, op. ‥1t., pp. 104-5.) 
MacMahon, Great Britain and Portugal should enter into mutual agreement to the effeet that the power In whose favor the award was made not "entertain any proposal for the aquisition of this territory until the defeated claiment had an opportunity of making the successful claimant a reasonable offer for the acquiaition of that territory either by purchase or some other consideration." ${ }^{l}$ The British minister implied that suoh an aoquieition by a third party would damage the confidence and security of relations.2 In reply to this, Portugal gave her fullest assurances. Marshal MacMahon docided in favor of Portugal, who st1ll has soverelgnty over the area. The op 1oode has more than passing interest for this thesis, because of the relation of the Delogoa Bay area to the negotiations of 1898 with Germany and Portugal. Closely related to th1 question was a treaty algned between the two all108, June 11, 1891. This treaty defined the spherea of influeno of each in Africa and safoguarded British interests in Delagoa Bay. Artiole VII of the treaty points this out:

\footnotetext{
1. Bixlor, op.cit., p. 106.

2. Britigh Fore1gn and State Papers, IXX, 1878-9, No 70 , pp. 38811 Toited by Bixler, op. ㅇt. pp. $104-105)$.
} 
- . The two powere agree that in the ovent of one of them proposing to part with any of the territories to the south of the zambesi as ignod by the se articles to their respeotive epheres of influence the other shall be rooognized as possessing a preferential right to the territories in question or any portion, of them upon terms similar to those proposed. 1

In 1894 Great Britain, Iearing that Germany might acquire Delagoa Bay, informed the Portuguese gorernment that she would not part with any rights whloh would diminioh the value of preferential claims granted to her in that area. 2

Relatione between Portagel and her protector remained the same until 1898 when Germany began to negotiate with England for possible acquisition of Portuguese colonies. These negotiations, of course, cast some doubt on the possible status of England and Portugal' alliance. However, within a jear after 1898, Bnglend had concluded another treaty with Portugal which reaffirmed the old relation. Th1s was the so-called "Mreaty of Windsor" and was signed on the 14th of October 1899 to give England reassurance of Portugal's attitude in the use of the Port of Lorenco Marques in Portuguese East Afrioa

1. British Fore1gn and state Papers, 1890-91, IXXXII, 32 Tolted by BixIer, op. c1t., pp. 104-5). 2. Bixler, op cit., pp. 107-8. 
by Haland in the event of a war with Tranavaal. 1

This treaty, of course, showed that England

otill had advantages to gain from her Portuguese

friendship and intended to keop them--her negotiations with Germany notwithstanding. The truth of this intention is evinoed jet again when Fngland olgned a treaty for arbitration of mutual disputea at Windsor, Hovember 16, 2904. The preamble to this is very aimilar to the numerous venerable treatiea of the past:

\section{FINDSOR TREATY}

Being moreorer desirous of confirming, by a further solem Agreoment, the friendship and allianse which have happily subsisted for 80 long a period between them, and the two nations which they represent, and of oliminating as for as possible, from their mutual relations, overything which might tend to impair or meaken that friendehip and allianog [a treaty of arbitration is concluded.] 2

This treaty was renewed in 1909 by Sir Bdward

Grey for a period of five yeare.

The treaties of 1898, 1904, and 1909 have more than paseing aignificance in that they wore a series of treaties steadfast to the age-old friendship declaration.

2. British Foreign and State Paperg, 97, pp. 68-9. This treaty Is the real ireaty of Windsor--rather than the Declaration of 1899 . 
and yet renewed at a time that they were counter to the more recent Germen treaty of 1898. The resolution of this enigmatic situation requires an Investigation of Buropean conditions between 18981914.

The diplematic eridence of the treaties leaver no doubt that England consistently wanted the friend ahip of her gmall ally, Portugal. Both countries received much benefit from this mutual understanding. Portugal had constant protection from her two large neighbors, France and spain, and a collaborator in oertain colonial negotiation in Africa. Sho also had a ready marizet for hor principal product, port wine, whose entire export trade contered in the English market, because of special privileges dating baok to Methuen's treaty of 1703.1 Fngland in return had a constant springboard for continental ware and wedge betweon Spain and France, as well a valuable commercial rights. The treaty series indeed had its advantages, but also its liabilitier. Fngland sometimes found that this friendship went contrary to the opportunistic policy of "muddling through." It also obligated her sometimes when she 
would not have beon. Then too, the English national diserse of gout might be attributed by some as a direct outgrowth of the treaty of Mothren, sinoe practically the entire output of port wine was sent to England as a result of this treaty. 


\section{CHAPTIR II}

RIGLAND, GERMANY AND THE INMERNA TIONAL SCEIE II 1898 


\section{CHAPTHR II}

\section{ENGLAND, GERKANY AND THE INTERNATIONAT SCEIS in 1898}

With the approach of the Twentieth Century there was a tremendous change in the values of international relations. The German and Italian wars of national unfieation ushered in a whole series of new problems and rivalries. The Europoan continent was being divided into armed camps whose relative power was evenly enough balanced to give each one reason to parse before antagonizing the other. ${ }^{1}$ Although international relations were still being carried out according to the archaic practices inherited from the old dynatic subject-state system, 2 the technological changes that the Twentieth Century had fostered and the expansion of rival imperialisms presaged an imminent change. International problems no longer were of a strictly European character. Signs were rapidiy appearing which indicated that the next conflict of interests would be worldwide. The world was undergoing a "diplomatic revolution"

\footnotetext{
1. Ward and Gooch, op. c1t., III, 266. p. 3.

2. Hale, Oron James, Publioity and D1plomeor,
} 
which required international problems to be settled on inoreasingly broader general Iines. 1

This rovolution had been given impetus by the resignation of Bismarck from the international scene. The absence of his diplomatic sagacity was soon notioed in the Weltpolitik policy of Germany. However, the revolution was in the making even before this. It started with the beginning of Germany's Pan-German and colonial aspirations, sweoping, in spite of his well-founded conviotions to the contrary, -ven the solid Bismarck into the ourrent which was to load his Germany into the maelstrom of Weltoolitik. When Germany became a colonial power she did much to upset the balance of Europe. German colonial dreams and schemes very soon created rivalries and hostilities, prinoipally with Fngland.2 This rivalry, coupled with Germany's new navy program, whose purpose by 1898 left no 111usion to the "two-power standard" theorists of Fngland, eventually forcod Fingland into one of the hostile camps. Therefore, Blsmarck's earlier acquiescence to a colonial empire
p. 596 .
1. Seton-Watson, R. W., Britain in grape, p. 771 .
2. Larson, I. M., A Short History of Ingland, 
later provided a logical exouse for a large navy. Thus he unwittingly laid the groundwork for England's final decision to participate in the Triple Entente and the inability of Germany to arrive at an alliance agreoment. Friendehip with Bngland wa a cardinal poliog with the Iron Chanoellor.1 He was eren opposed to a German navy powerful enough to agltate Fngland. 2 What he did not soe was that his supposedif innocrous colonial polioy, whon administered by hands other than his own, was to become the otimulant that upsot the equilibrium of his plan for Germany's seourity and presaged a fatal navy rivalry as well.

But in the oarly $2890^{\prime}$ no one could yet foretell what the situation erentually would be and that Germeny would be more hostile to Fngland than any other power. All that was evident was a change in world politic which was definitely unfarorable to England's favored position. At the time German agitation was only one of a large number of perplexing problems that could not be olearly understood because

1. Count Wholm von Bismarck to Chancellor Bismarck, August 19, 1885, Grosse Politik der Europaischon Kabinotto, IV, I34.

2. Hamman, ㅇ․ eit., p. 70 . 
diplomats and statosmen wero still greoping at prinolples whose usefulness had already elipped away with the approach of rapid communication and the machine age.

In fact, in 1887, Bngland had made a friendly entente With Italy, one of Germany' partners in the Triple Alliance. 1 Femlig relations between Windsor and Potsdam were very cordial. 2 These relations were cordial enough to give the Iinal impetrs to Russia to enter into an entente with Prance. Thus Ingland, for a time at least, was not in such an unfavorable position with reference to Germany. In fact, she was in a position to cast a deciaing rote botween the two aldes that were now forming. 3 Germany did not realize this. As yet, most of the British diplomats could not grasp the situation because of their encumbrance by the poliey of the past. Both powers were at an important historical crossroad and did not know that they were.

In the 1890's in England forelgn relations were till influenoed by the timeworn prinolple of ibolation, p. 125 .

$$
\text { 1. Fry, sidney B., Orisins of tho horld Var, }
$$

2. Ibid., p. 125.

3. Seton-Wation, op. e1t., p. 570. 
so often called, "splendid," but at best, precarious. England, since Irafalgar, was the undisputed mistress of the seas. She, therefore, enjoyed an independence of action rarely obtained by other powers of that day. Her goographic insularity further amplified her aloofness from nearby European problems, which for her were never so much causes of a set system of policy as individual motivations for particular opportanities. After Fapoleon, England's cabinet trimmed her sails more and more to a line of action epitomized by Canning's famous phrase "with orery British Minister the interests of Angland ought to be the shibboloth of his policy."l The only sot polioy was that of opportunism or what is more commonly known as the policy of "madaling through." For over fifty years England steored away from permanent alliances with any continental nation. The sole exception was Portugal. The "derilish" Palmerston opitomized this poliog woll by stating:

I say it is a narrow poliog to suppose that this country or that is to be marked out as the eternal ally or the perpetual onomy of Fngland. Wo have no eternal allies and wo have no perpetual enemies. Our interests are eternal and perpetual and those interests it is our duty to follow.

$$
\begin{aligned}
& \text { 1. Seton-Watson, op. o1t., p. } 459 . \\
& \text { 2. Ibid., p. } 459 .
\end{aligned}
$$


Such a viewpoint was Inherited by the conservative ministry of Iord Salisbury. His work at the end of the contury attempted to follow the old polley. In many respects, however, he began to realize some neod to cooperate in continental matters. But even though he frequently inclined to cooperation, he was partioularly adverse to pledglng England in adranoe to act on circumstanoes which had not jot arimen. 1 He was constantly adverse to formal alliancer. 2

In faot, it was only when the danger of war with South Africa appeared that Finglish diplomacy began to understand clearly its position in relation to the other aspiring empires stimalated by the opening of new areas of the world, scientific achievements, the development of large scale industry and commerce and the increase of popalation. These sought an outlet for their energies which might preserve the precarious balance in Europe. 8 In going overseas, however, these powere actually caused the upset which

1. Tomperley, Harold and Penson, HIIIan, Fonndations of British Fore1gn Polior, p. 62I.

2. Ward and Gooch, op. o1t., II, 261.

3. Ib1d., p. 267. 
they sought to aroid. 1 Inglend, the earliost of the expansionists, had contiguons conflicting interests in almost every section of the earth where the others tried to stake a claim.

Fngland was facod with the porpotual Ruseian effort to expand her Empire in directions that wore dangerous to her colonial possessions. The Russian danger was particularly perplexing because the largo Russian land mass made it possible for that country to spread farther afield without encountering the dengers of the Brition fleet on the high sees where alone she was supreme.

Britigh claims and interests encountered Ruseia's at points widely apparated over the world. Russia's expansion into Mancharia was seriously menacing England's commercial and naral superiority In the orlent.2 The coloseal weight of the Trarist Empire was being felt more and more on the borders of England's Indian Fmpire. 3 Rusaia was continually nipping at the hools of Turkey, whose maintenanco ant1l late in Salisbury's ministry England regarded

1. Ward and Gooch, Op. alt., III, 26\%.

2. Fay, op. cit., pp. 128-9.

3. Ward and Gooch, op. cit., III, 267. 
as an essential to her imperial salety. ${ }^{1}$ Iikewise Ingland had incurred the hostility of France in several Instancos. Lord Edward Grog, Fore1gn Minister of Fingland during the World War geve the following picture of the situation:

- There was constant friction, rising on the slightest provocation to quarrel and hostility, betwoen Great Britain and France or Russia. The ground swell of 111-w111 neter ceased. British interests tonched those of France and Rusala in many parts of the World and where interests touch, an atmosphere of 1II-Tili is always dangerous. The blackest suspicion thrives on it, I1ke noxdous growth under dark skies in murky air. 2

Even previoua to 1898, England had hed considerable disagreement with France about the colleotIon of debts and the gradual establishment of guzerainty in Egypt. In this situation Germany gave some moral support to England. 3 Perhaps this was a carry-over from Biemarck's policy of keeping France and Fngland disturbed so as to turn French ejes from Germany. However, Bismarok also encouraged Frano's colonial policy at the same time so that there would

1. Fay, op. olt., p. I2\%.

2. Grey, Bdward, Twenty Five Yeare, II, 11.

3. Hicholson, Harold, Portrait of a Diplomatlot (Sir Arthar Nicholson), p. 94. 
be bad blood between England and France. 1 England also had to be careful of French expansion in the Indo-Chinese area. ${ }^{2}$ In 1898 the re was considerable hostility about the Nigerian boundary in Africa.J Major Marchand of Franoe and General Kitohener of Fngland met under warlike conditions in the disputed African area. This was but the final of a series of unfriendiy events between the two snoient enemies. An early war appeared to be inevitable.

While Englend was faced with all of this rivalry Germany was making her own late bid. Most of the unclaimed territory of the world at that time was situated in one of the most disputed areas, namely, Africa. Germany bocame neighbor of England on both the east and west coast of Africa. She attained these separated areas just in time to compete at crose purposes with the remainder of the African colonial powers in attempting to join theix var1ous scattered possessions. Cecil Rhodes was beginning to conjure up his visions of the cape-to-

7. Schmitt, Bernadotto, Ferlend and Germany 1740-1914, p. 134.

2. Ward and Gooch, op. cit., VIII, 288. 3. Fay, ap. c1t., p. 128. 
Cairo empire. On top of all of this, Italy was making a bid for Abyseinia. Of all of Ingland's danger spots, Afrioa provided the greatest number of possibilities of an open conflict. In spite of the Anglo-German treaty of 1890 by which England was given all German claim to African Zanzibar for Eraropean Helgoland, relations gradually, almost imperceptibly, became strained by a continuous succession of these erents.

Potentially the Krueger Telogram opisode was juat ouch an occasion. It further indicated that Germany already was not anxlous to build up diplometic cordiality botwoon heroolf and England, the doclarations of the Kaiser and the Inoup of Europe to the contrary notwithetanding. This evidence becomes more pointed when one observes that the date of the raid was 1896, two yeare before 1898 whon Chamberlain's bid for a German allianee was refuged by Germany. Yet the effects of the event were distinctig felt jears after its occurrence. It was a orisis that could have led to an eclipes of $B_{r}$ itish supromoy in South Africa. As it finally resolved itself, the resulting suspiolons of German reactions became permanent feature in Anglo-German 
relations. 1 Retrospective examination indicates that the gradual deterioration of English and German rolations had dofinitelg begun with the Jameson Raid and 1ts direot result, the Kaiser's telegram to President Krueger of Iransvaal. 2 Germany's conduct in this situation was the initiating cause of the Iinal breakdown of Bismarck's policy of friendship with England.

For some jeare prior to 1896 , because of her South African colonial interests, Germany had been extremely friendly with the Boer Republic, England's big problem in lower Africa for over a generation. ${ }^{3}$ In fact, this friendiness with the Boors grew in proportion to the animosity that developed between the German and the English. Economio and political relationship became so intimate between the German and Boor by the middle of the "ninoties" that Germany controlled over a fifth of the foreign investments in the Boer Republics.4 Big comercial houses from

I. Carroll, W. M., Germany and the Great Powarg, 1866-1914, p. 362.

2. Iove11, R. I., The Struggle for South Africa, p. 368 .

3. Brandenburg, Frioh, From Bigmarck to the World War, p. 80 . 4. Carroll, op. e1t., pp. 362-3. 
Germany maintained thriving branches in Pretoria and Johannesburg.

The Germans had a sentimental sympathy for the Boers as well as a materialistic one. They regarded these Dutch farmers as a "small people of Germanic blood struggling to maintain thoir independence" despite the pressure of a colossel England. 1 For these reasons the colontal enthusiasts of Germany had long earmarked the area as a desirable and likely possession--of, if not a position, at least a means of challenging and blooking Britioh superiority in South Africa. This viewpoint was exemplified when President Krueger to a large group of Germans asgembled at Pretoria on the Kalser's birthday expressed his gratitude for past German aid and confidence for future help. Fngland protested that acoording to the Treaty of Protoria (1884) and the Convention of Iondon (approved by Bismarck, 1881), the Republio could not independently make ang arrangement with a foreign power. Germany showed her stand by promptly informing England that her interesta required an economically independent Transvaal with opon communication from Pretoria to Delagoa 
Bay in Portuguese Mozambique. I

These comments colncided with German actions in the construction of the rallroad from the Portaguese Mozambique port of Iorenzo Marques to Pretoria. This was the Transvarl's only non-English outlet to the sea. The project recelved considerable financial oupport from Germany. Such action, threatening the English position not only in the Transiaal but in Portuguese East Afrioa wa emphasized particularly by the appoarance of two warshipa at the port and the dispatch of a congratulatory telegram to President Krueger by the Kalser. ${ }^{2}$ Fngland had attempted to forestall the damage this railroad would do to her African Empire by securing a lease to Delagoa Bay, the Mozambique terminus of the road. ${ }^{3}$ This effort was thwarted in 1893 by Germany and the Onited States, who interfored ostensibly because they foared that such a les ge would damage their holdings in the portuguese railroad.4 Brandenburg even states that the Anglo-German animoity had its inception at this

1. carroll, ㅇp. c1t., p. 363.

2. Brandenburg, op. cit., p. 80 . 3. Lorell, op. eit., p. 342 . 4. Brandenburg, op. o1t., p. 45. 
tine. 1

The railroad episode of Julg, 1895, was still sore in the minds of Hngland and Germany when Sir Edward Malot, the British Ambessador, made his final leave of the German Imperor before replacement. In his conversations he wont beyond what a circumspect farewell would require by reminding William that Germany's attitude in reforence to the African si tuation and Boer problem oould cause trouble. 2 The Kalser sald that Malet eren mentioned "war for the sake of a few square miles of nigger and palm trees; war with Queen Victoria's grandson and Bngland's only friend." 5 salisbury, the Prime Minister of fingland, expressed his surprise to the German Ambaseador when he learnod of this remark and atated that Malet had had no offiolal instructions to make such a statement. 4 Iovell implies that Joseph Chamberlain, the Colonial Seoretary, might have inspired Malet to utter the remark. 5 However,

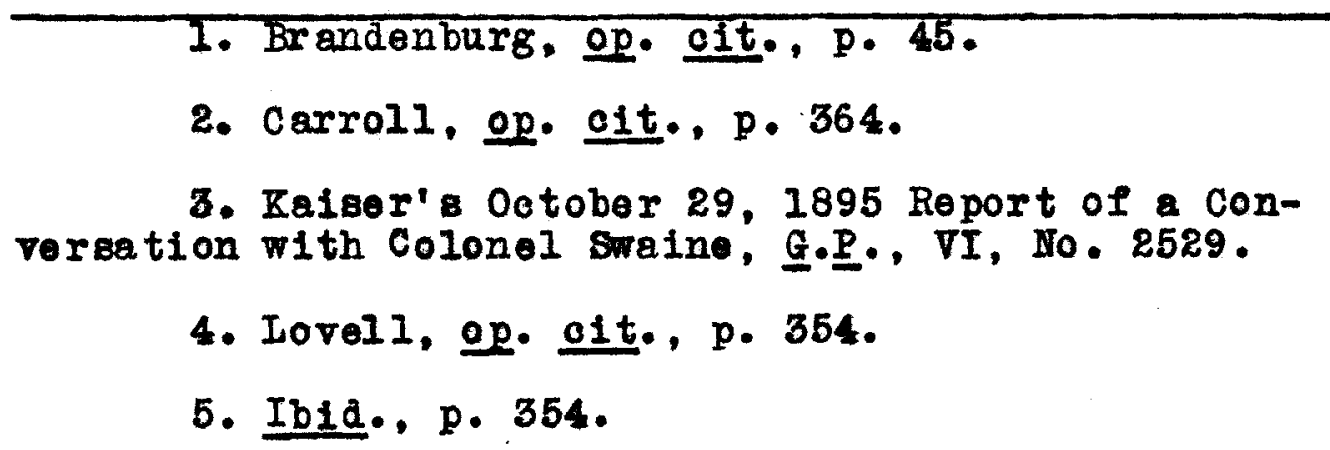


J. T. Garvin, Chamberlain's apologist, supports

Malet's denial of the remark. ${ }^{1}$

Regardless of the exact wording of Malet's

remarks, the Kaiser's sabsequent comments to the

British Military Attache, Colonel Swaine, show that

he might have even welcomed the excuse they or

similar remarks gave Germeny to state her position.

In his comments to Sraine, Tilliam

- onded with a threat that if Fngland continued to 'Insult and fool' the Drelbund as she had for the past oeven years, ho Fonld bo

'simply forcod to make common canse with France and Ruesia.' Britain, ho conoluded, oould only escape from her isolation by 'ooming out unreservediy and openly on the side of the Triple Allianoe or against $1 t^{\prime} \cdot 2$

Here the Kaiser exposed himself and the ourrent German polioy--to browbeat England and at the same time "make great oapital out of this story, also for possible naval demand to protect our growing trade." 3 Brandenburg oubstantiates this viewpoint somewhat, even though he does place the Kaiser's remarks in a more excusable eotting. 4 The Kalser had made up hi. III, 65 .

1. Garvin, J. I., Ilfe of Joseph Chamberlain,

2. Soton-Watson, op. c1t., p. 576 .

3. William II to Marschall October 25, 1895 (Note), $\underline{G} . \underline{P} ., X I$, No. 2580 .

4. Brandenbarg, op. cit., p. 81 . 
mind that he was not going to troat England with "kid gloves" ang longer; if friendly persuasion wouldn't do the triok, intimidation would. He was resolved to show definitely to England the dangers of isolation and how much she noeded Germany ${ }^{1}-$ at Germany's price, however.

At the time that Malet made this purported statement, Marschall, the German Foreign Seoretary, stated that the Gorman governmont's interests in the Boer Republic had of necessity to oppose any possible incorporation of those states into British Rhodesia. Public opinion in Germany domanded that the government make such a stand. 2 He countered Malet'a remarks by seying England could not afford to antagonize Germany because she had too many onemies. 3 Germany's stand was based on insistent reports that Rhodes' South African Company was plotting a revolt of the Uitlanders in the Transvar. 4

Such was the situation when news flashed over the world that Dr. Jameson, Cecil Rhodes' administrator

\footnotetext{
1. LoveII, op. c1t., p. 363.

2. Karschal1's Report October 15, 1895, G.P.., $\mathrm{XI}, 5$.

3. Ibid., pp. 5-7.

4. Carroll, op. cit., p. 364.
} 
of the South African Company" territories and head of private company police, had crossed the border with six hundred men into the Transvasl. The arowed purpose of this rald was to come to the ald of an uprising of persecuted Engligh vitlanders (alions), supported by money and arms from Rhodes. ${ }^{1}$ The conspiracy was a complete fiasco. HOWorer, it might have had some chance for success had it been confined to an internal revolt of Uitlanders desiring a "new republic." But, when the Jameson party, coming from South African Company territory, Was superimposed upon the "internal revolt," the plot falled. Jameson disregarded a postponement of the uprising and impatiently "jumped his gun" on December 29, 1895. As a result, the Uitlanders wore forced hastily to summon their mon together at an extreme disadvantage. They were easily oreroome by President Krueger's troops at Krugersdorp. This "putach" was definitely Rhodes' responsibility. The British Cabinet had no part in the raid although Chamberlain probably $\mathrm{knew}^{2}$ of it and consequently, was guilty of the sin of "omigsion if not commission." 3

\footnotetext{
1. Bryco, James, Briton and Boer, pp. $35 \mathrm{f}$.

2. Garvin, op. c1t., III, $74 \mathrm{ff}$.

3. Carroll, op. itt., p. 365.
} 
When nows that the raid was started reached Europe, Berlin instructed Count Hatzfeldt, the German Ambassador at Iondon, to inquire if the British Government sanctioned the raid. 1 Marsehall laid down a flat prinoiple that Germany would not tolerate the annexation of Transvaal. 2 He informed the now British Ambassador, Lasoollos, that in splto of repoated warnings of the denger of incurring Gorman illwill in South Afrioa, Theland did not pay the least bit of attention. 3 Salisbury and Hatzfeldt informod Berlin via Iascelles that there was no official endorsement of the raid. Salisbury did this oren before its outcome was known. 4 Nevertheless, a formal note of protest was sent from Berlin. The German Ambassador was instructed to ask for his passport if he received an impresaion that the raid was authorized in Iondon. At the same time Germany sounded out France to sec if she would cooperate (temporarily) with Germany in stopping Bngland. The purpose of this gesture wa to make England again

\footnotetext{
1. Brandenbarg, op. elt., p. 88 .

2. TIllog' Memorandum, B.D., I, 326.

3. William II to Marsehall, January 1, 1896 , G.P., XI, NO. 2514. 4. Seton-Watson, op. it., p. 576.
} 
realize the danger of 1solation and the need of jolning the Triple Alliance.1 A request had been made of Portugal for permission to send a detachment of German troops to maroh through Portuguese African territory to Pretoria, Transvaal for the protection of German subjects. This request was denied by the Portuguese minister, Marquis de Soveral. According to Eckardstein, Hatzfoldt's assistant at Iondon, this one gesture did more than enything else to prevent an outbreak of war between England and Germany.2 a passage of troops before England coula have retriered the situation, might have started a juggernaut, which could not be atopped eren after the primary cause, the raid, had been proven to be independent of governmental sanction.

News soon came through that the raiders had beon captured and that the danger to Transvarl was over for the time being. Immodiately tho German government seurried about to retrieve a situation that could have been dangerous in spite of the fallure of the raid. A telegram was flashed to Hatzfeldt to request the return of the note of protest.

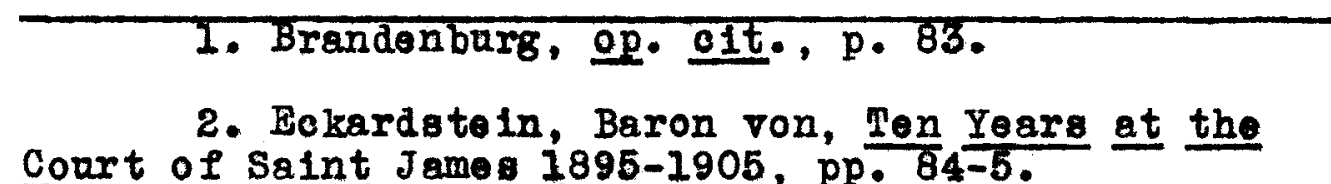
Court of Saint Jame日 1895-1905, pp. 84-5. 
Inokily this was possible booause Selisbury was away and had not jot been able to open the note. ${ }^{1}$ It was returned to the somewhat emberrassed Germans. However, the salraging of this message was almost wasted offort, for in the next fow days Germany performed one of the greatest diplomatio blunders of the centary when she sent the famors congratulatory telegram to President Krueger.

$$
\text { The failure of the raid was in a sense a }
$$
disappointment for the Kalser and his government. If the raid had been suceessful and could have been attributed to Hngland, Germany would have had some cause for the establishment of a protectorate over the Transtaal. This might have been one of the reasong why Germany at this time approached her erstwhile enemy, France, and also Rassia, for posa1ble anpport. She could make temporary use of her European rivals becarse of their indignation at the raid. Howerer, the French sew through this easily onough.2 Germany went so far as to offer Krueger a protectorate on January $2,1896.3 \mathrm{Dr}$.

\footnotetext{
1. Brandenburg, op. it., p. 84.

2. Seton-Watson, 오 cit., p. 578 .

3. Lovell, op. clt., p. 369. Lovell bases his tatement on Konrad Iehman's account of a Memorandum by Ileutenant Mesmer-Selden, one time German Military
} 
Fredrich Thime, one of the editor of the Groses Politix in an artiole, "Die Krugerdepsche," has stated that Transvaal had feared the establishmont of a German Protectorate before the Jameson episode made such an action possible or more desirable to the Boers. I Wilholm oren offered Dr. Leyda, Boor Representative-at-Large in Europe, military help and added "if Lorenzo Marques (Portuguese Mozemblque's port of entry and chlef source of Boer supplies) ever ohanged orners, it could only come into German or Boer hands, 2

Howerer, Salisbury's "oorrect attitude" had oheated Germany of any reasonable pretext for further intervention at this time.3 Nevertholess, the Kalser, at least, folt that something mast be done. So on January 3,1896 , a meeting was called in Berlin which was attended by the Kaiser; Hohenlohe, the Imperial Chancollor; Marsohall, the Forelgn Minister; and Dr.

Attache at Constantinoplo. This Momorandam is quoted in Chancellor Hohenlohe's Memoirs. Iohman articlo "Die Vorgeschichte der Krugerdepsohe" appeared in Arohir fur Politik und Gesohiohte, 1925.

1. Lovell, op. c1t., p. 364.

2. Soton-Watson, op. o1t., p. 577 .

3. Brandenburg, op. oft., p. 84. 
Kaiser, the Colonial Secretary. I Ilkewise,

Secretary of State for the Navy Hollman, Commanding

Admiral Knorr, and Chief of Naval Cabinet Senden

were present. 2 The Kaiser made some very interest-

ing, if not fantastic, suggestions which Marschall

explainod in his diary.

January 3rd. At 10 o'clock conference with H.M. - - H,M. unfolded somothat astonlohing projects. A protectorate over the Transvaal, but I talked him out of that at once. Mobilization of the Marine Infantry. The dispatch of troops to the Transvaal. And upon the Chancellor's objection: 'That would mean war with England,' H.M. replied, 'Yes, but only on Iand." Then it was resolved to send Scheele (Colonel Beron von Scheele, Governor of Gorman Bast Africe until February 1895) to the Transval to reconnoitre. Also an unfortunate idea. Finaliy H.M. at my suggestion sont a gongratulatory dispatch to President Krueger. 3

The telegram was finally sont then as the cabinet's way out of a dilemma. It was in Brandenburg's words "a sort of lightning conductor for the Kaiser's energJ." The final mossage itself was drafted by Marschall, but it was far from boing his own wish and Idea as the Kaiser later accused. Marschall 5

1. Brandenburg, op. elt., p. 84.

2. Hamman, op. oft., p. 68 .

3. Ibid., pp. 68-9.

4. Brandenburg, op. cit., p. 84.

5. Hammany op. ait., p. 67 . 
was merely following a line of action which would be the least of sereral evils. He was even obligated to alter several words in the original message written by Herr Kalser, the Colonial Secretary, to suit the Kaiser. ${ }^{1}$ The words congratulating Krueger for "preserving the respect for your government" were changed to "preserving the independence of the country against attack from outside." 2 The full message reads as follows:

I express to you my sincere congratulations that you and your people, without appealing to the ald of frlendly powers, have succeoded, by your own onergetic action against the armed bands which invaded your country as disturbers of the peace, In regtoring peace and in maintaining the independence of the country against attacks from without. 3

This was an improvement over such original fantastic suggestions as having Germany declare war on English South Africa and remain at peace with England at tho same time or to get France to cooperate with Germany in Irightening England in a war overseas. Nevertheless, the message still contained onough dynamite to ohange the opinion of the English public toward

\footnotetext{
1. Carrol1, op. olt., p. 369.

2. Brandenburg, op. c1t., p. 85. I, 237 .

3. Langer, W. I., Diplomacy of Imperialism,
} 
Germany to one of definite hostility. The last phrase of the message was a plain endorsement of the Transvarl's claim to complete independence. This was contrary to the London convention of $1881^{1}$ which recognized Fngland's sovereignty over the external affairs of the Dutch African Republics of Trangvaal and the Orange Pree state. The telegram, a greater blunder than the rald over was, threw a shadow over Anglo-German relations which subsequently grew darker. 2 saliabury frankly told Eckardstein that it was sily from the point-of-viow of German interests.3 The Insanity of the situation was realized all too well by Hatzfeldt who contemplated resigning as a result of the blunder and the irreparable damage it had done to British-German relations.4 His only reason for staying on was to "make good as far as possible the harm done." 5

The Jameson Raid and the African situation in general were indications to some Englishmen that

1. Carroli, op. cit., p. 362.
2. Soton-Wation, op. cit., p. 578 .
3. Eckardstein, op. cit., p. 85.
4. Ibid., p. 87.
5. Ibid., p. 87.


England was in need of an ally. Among these was Joseph Chamberlain, Colonial Secrotary in Sal18bury's second cabinet. Chamberlain was convinoed that "Bplondid Isolation" was a bankrupt policy." Frgland had hardly a single friend. Something had to be done quickly. She desporately neoded allios who would work for peace. Chamberlain and Arthur Balfour, acting a Prime Minister in his uncle, Iord Salisbury's, absence, considered that, deapite the numerous Anglo-German differences, Germany would be the most logical candidate for possible partnerahip in a defonsive allianoe 2 sinoe most of the differences between the two countries were still in the stage of annoyanoes. Chamberlain was convinced that an ally was absolutely necessary. He did not believe that an alliance with even Russia and France was impossiblo.3 However, he was more convinoed that Fingland's diferences with Germany, partioularly coloniel, were not nearly as divergent as with other powers. Consequently, Chamberlain began to make inquiries as to the possibility of some kind of alliance

1. Garvin, op. olt., III, 254.

2. Brandenburg, op. oit., p. 106.

3. Garvin, op. ㅇt. . III, 255. 
With ingland. But, his negotiations were not officially those of the cabinet. Henoe, they were regarded as a private matter.1 Through the intermodiary of Baron Eckardstein, the German Ambassador'. Assistant in Iondon and an old acquaintance of Chamberlain's, a meeting with Hatzfoldt, the Ambassador, was arranged. 2 The meeting ocourred March 29, 1889. At this time it was unofficially proposed that Thgland might not only reach an onderstanding but - ven conclude a defeneive alliance with Germany. 3 This is substantiated by Hatzfoldt. 4

Here Germeny at last had in her hande what Bismarck had desired and what he had striven for so hard in the last years of his ministry-an alliance with England.5 On the surface at least this was what Germany wanted or thought she wanted in $1896 .^{6}$

1. British Documentg, V01. I, Foreword. Also Chamberlain's Memorandrm, March 29, 1898, Garv1n, ㅇ․ 소., III, 259-60.

2. Garvin, op. c1t., pp. 255-256. March 29, 1898.

3. Ibid., p. 260. Chamberlain's Memorandum of 4. Hatzfeldt to Bulow, G.P., XIV, pt. I, $196-199$.

5. Hammanp, op. oit., pp. 24 ff.

6. Supre, pp. $37-38$. 
Howerer, now that she had the posaibility of securing what sho wanted, she let it go becarse she thought sho could get oven better terms in view of England's predicament. She was skeptical, with some justification, for just a few months before a similar proposal had been mado to the Tsar. 1 Then, too, the favored Navy program of the Kalser was now beginning to displace many of the older ideas and policies. Another distracting factor was the unofficial nature of the proposalo from a responsible cabinet. Bulow, the German Minister of State, said that he could not trust the uncertainty and anrellability of Rngland's parliamentary government. 2 Iikewise, Bulow objected to such an arrangement on the grounds if such a treaty were made by Germany "we must come to the assistance of Ingland whenever she was attroked in India or Canada or in som other of her numerous colonies and oversess possessions, while England remained with grounded arms if Russians marched against Austria or the French against Italy."3 strangely enough, the

I. G.P., XIV, 243.
2. Bulow, Prince Bernhard, Memoirs, I, 380.
3. Ibid., p. 379.


Kalser, too, was instrumental in creating the dead10ck. The British overtures were, he told the Taar "by my commande cooly and dilatorily answered in a colourless manner." 1

Salisbury, the Prime Minister, upon his return from France, where he had been resting beoause of his health, was probably happy that Chamberlain's auggestIons had not been more productive. He later told Hatefeldt that while he agreed with Chamberlain in abstract in desiring a rapprochement with Germany, he did not favor a formal alliance or treaty necessary unt1l a specific case of nocessity arose.2 salisbury had not yet been convinoed that "splendid isolation" should be given up. He was in truth the "residuary legatee of the gystem of Castlereagh." 3 Howerer, the "ice had been broken." Both powers seemed to agreo - . that the most important task of both governments was gradually to dispel the ill-humour still prevaling between the two countries, by showing a spirit of accommodation in minor questions, and thus to prepare public opinion on both sides for a definite political agreement.4

\footnotetext{
1. Nicholson, op. cit., p. 94.

2. Hammana, op. oit., p. 79.

3. Cocil, Algernon, British Foreign Seoretaries, "Salisbury," p. 309.

4. Hammany, op. oft., p. 79 .
} 
Chamberlain as late as June 2, was still roported by Hatzfeldt as desiring "to work by leisurely but Iriendly efforts for an elliance with Germany and so to act that the way was left open for any understanding later on."nl Salisbury's unrelenting reluotance to entertain seriously talk of a complete alliance with Germany was based on his suspicion that Germany dangled the prospect of such an alliance before Fngland fust onough to keep her interested in times of difficulty. Germany did this merely to wrangle colonial concessions from Fngland and not to real1ze the purported purpose--a permanent understanding resulting from an alliance. 2

The German Ambassador continued to discuss the question academically with Saligbury with the hope that something ooula be gained for Germany in the future." It so happened that the "future" was just a Iitle over a month away and the "something thet oould be gained" was the Portuguese colonies.

Thus by June 1898 the English Government had come to a partial realization of its adverse situation

240. Hatafelat Report of June 2 and $3, \mathrm{G} \cdot \underline{\mathrm{P}} \cdot \mathrm{XIV}$,
2. Brandenbarg, op. cit., p. 145.
3. Ib1d., p. 114.


of "splendid 1solation." England was in danger of being without frionds at a time when her own colonial problems were becoming acute in South Africa. To forestall any embarrassment in the growing difficulties, England indioated that she would possibly bow to circumstances and seek aid among her rivals and potential enemies; at the time Germany was the most logical one from whom to secure such aid. 


\section{CHAPTER III}

STEPS TOWARD AN ANGLO-GERMAN

COLONIAI AGREEMENT 


\section{CHAPTER III}

\section{STEPS TOWARD AN ANGLO-GERMAN COLONIAL AGREFMENT}

Chamberlain's initial efforts to ostablish a regular alliance between Germany and Fngland proved unsucessiful because of German distrust of Fngland, German indecision as to whether she should turn more to Russia or England for added support and the unenthusiastic attitude of the Salisbury element in the British Cabinet. Nevertheless, both powere left the back door open. 2 Germany indicated that while a large scale understanding was impossible, there was still a possibility for a aettlement of specifie minor matters. 3 This apparently conformed to sal1sbury's Views as expressed to Baron Staal, Russian ambassador, When he was inquiring as to the rumored possibility of an Anglo-German alliance. At this time the British Prime Minister replied, "Alliance (with Germany) non; rapproohement oul."4 Consequently,

1. Brandenbarg, op. olt, pp. 113 ff.
2. Supra, Ch. II, pp. 51-52.
3. Buzow to Hatzfeldt, June 8, 1898, G.‥ IIV,
Jo. 251.

4. Hammenp, op. oft., p. 80 . 
the 6 tage was well set in 1898 for spocific nogotiations for the eventual disposal of Portuguese colonial possessions, particularly in Africa where there was such a duplioation of German and English interests. According to Hamman, Germany realized that the proximity of Portuguese possessions in Africa to Transvaal, German East Africa, German South Rest Africa and the British South African posegsions provided amplo opportunity for embarraseing complications. The Reich soon conceired the idea of avoiding hostile complioations by mans of an Anglo-German agreement concerning Africa.l Ih1s, however, placed Germany on the horns of a dilemma-how was she to come to an agreoment with England in Africa and yet not give up rights and possessions of her own? Evidently, a catalyst, lightning conductor, or scape-goat was noeded. The embarrassing condition of Portuguese finances by May, 1898, plus the growing strategic importance of the location of her colonies were ooincidentaliy opportune for the diplomatic sparring of Fngland and Germany. By May of 1898 Portugal was in

$$
\text { 1. Hammanq, Qp. O1t., p. } 80 \text {. }
$$


desperate need for money to meet not only the forthcoming award of arbitration against her as a rosalt of her confiscation ${ }^{l}$ of British rallroad interest. in Mozambique (East Africa), but even hor ordinary debt engagement 8 , on which the payment of interest had been suspended. 2

So desperate was this need that the Portuguese government sent its Governor-General of Mozambique, Major Moushino de Albuquerque to Paris, Iondon and Berlin to make sounding as to the disposition of these various governments. Portugal, at this time, was oven offering her colonies in Africa for sale or as a oollateral for a loan. ${ }^{3}$ This visit by Moushino proved a revelation to him of the militarism that pervaded Germany. He, as governor of Mozambique, the nearest non-Britioh neighbor of tho German favorito, Tranevaal, saw danger to his country from Germeny. So "he determined that his country should maintain the best possible relatione with Germany and the Transvaal compatible with a

1. Kr. Bertie 8 Memorandum on kngland and Fortagal in Africa, May 1, $1898, \underline{B} . \underline{D} . I$, No. 65.

2. Hamman, op. eit., p. 82 .

3. Ib1d., p. 82 . 
close understanding with England." 1 Consequently, concurring with the Marquis de soveral, longtime Portuguese statesman and Ambassador to Iondon in 1898, he thought that his gorernment should adopt a suggestion from England. That is, that a loan should be raised in England on the guarantee of revenues of the Portuguese oolonies, including Ioronzo Marques, "coupled with a thorough understanaing with Hex Majegty's government." 2

This gesture, more favoreble to England than the other powers, wa in keoping with Portugal's ancient friendship with Fngland 3 and the Treaty of proemption that she had signed with Por angal in 1875, granting her pri or righte to purohase Mozambique if Portugal were alsposed to sell it.4 However, It could pique Gormany, who because of the proximity of Mozambique to German East Africa and the Boor Republic, belleved it to be in her sphere of influence by the right of justioe if not by 1 aw. In fact, already during the Jameson crisis, the

1. Bertie's Memor andum on kngland and

Portagal in Afrioa, B.D., I, 45 .

2. Ibid., p. 45 .

3. Supra, Ch. I.

4. Supre, Ch. I, pp. 17-18. 
Kai ser himelf admitted that Germany was out to get Iorenzo Marques, Mozambique's chief port. ${ }^{1}$ Chamberlain strongly suspected Germany of having design. on this locality as late as 1898.2

Thus even before 1898, Germany" nowly aroused colonial ambitions prompted her to take adrantago of Portugal's precarious pecuniary sitaation. She showed herself extremely interestod to furnish credit guaranteed by the customs of Angola, Mozambique, and Timor. ${ }^{3}$ The Portuguese colonies were not only tempting prizes, but were also exasperating inconveniences to Gorman African polioy; the role Portagal played by refusing transmit to German troop during the Jamoson or1818 was proof.

The German govermment lost no time in bringing pressure to bear on Fngland. Although the German Bmpire had shown an interest in the Portuguese colonles as early as the Jameson situation, it was particularly anxious to secure concessions in Portuguese Africa after the Moughino mission gave glaring

1. Hammanp, op. eit., pp. $10-11$.
2. Count Hatzfoldt to the German Foreign Office,
June 14,1898 , Dugdalo, E.T.S., German Diplomatio Doouments 1870-1914, p. 29; 11 so G.P.. XIV, 261. p. 325 .

3. Guodes, Armando Marques, Alianca Inglesa, 
Indication of Portuguese finanoes. On June 3, 1898 , the Kalser indicated, on marginal notes on the report of Hatzfeldt (the German Ambassador to Iondon) to the Forelgn Offioe, that German colonial interests demanded consideration of the acquisition of some of Portugal's African possessions. 1 Therefore, on June 6, 1898 when Count Tattenbach, German Minister to I1sbon, learned that the Marquis Iuis de Soreral had been sent to England with specific instruction to obtain money by mortgaging the revenues (not the sovereignty) of Mozambique, Angola and other Portugue se colonies, he telegraphed Berlin at once.2 This information soon produced action, for on June 14, 1898, Hatzfeldt called on salisbury and made some roundabout inquiries as to what Soveral was proposing. 3 Salisbury was ovasive. However, he indicated that the problem had been referred by him to the Colonial secretary, Joseph Chamberlain. He promised Hatzfeldt that he would

\footnotetext{
1. Dugdale, E.T.S., Op. cit., Bernhard von BuIow in Berlin to Count HatzfeIdt, June 8, 1898, III, 27-28. Also G.P. XIV, 261.

2. Ibid., p. 27, editorial note.

3. Salisbury to Viscount Gough, June 14, 1898 , B.D., I, 48 .
} 
inform Germany in due time if steps were undertaken in reference to the Portuguese colonies which woald conoern the legitimate rights and interests of Gormany. Salisbury was completely aware of German sensitiveness in African matters. I He had learned that too well during the Jameson Raid crisis. He was eager to keop Germany placated. According to his own report of the convereation, Hatzfoldt said he

- - explained in friendig, but omphatic terms that ono-gided action in the matter here involving actual or contemplated parsing of Portugal's oovereign rights in those colonies into Britiah hand would make a very bad impression with us and also would not tend to improvo our relations which wo both desired and that the que stion was a politiogl one, whieh he, saliebury, and not Chamberlain would have to decide.?

The gauntlet was definitely down. However, Bulow must have believed that there was a strong possibllity of being able to persuade or force England to enter into a joint negotiation, because when the French ambassador asked if he (Bulow) had any information on a possible Anglo-Portuguese negotiation, he replied in a depreciating tone. 3 Nerertheless, ho was careful to include

1. Brandonburg, op. ․t., p. 114.

2. Hatzfeldt to Foreign Office, June 14, 1898. Dugdale, E.T.S., op. alt., III, 29; aiso G.P. XIV, No.261.

3. Bulow to Hatzfeldt, June 17, 1898, Dugdale, E.T.S., op. elt., III, 30; Also G.P. XIV, 266. 
In information telegraphed to Hatzfoldt, the suggeation that if Angland knew that Franoe was interested, she (Angland) would negotiate muoh more readily with Germany. The next meoting between Salisbury and Hatzfeldt brought out more speolfic comments. Hatzfelat asked if Bngland would join with Gormany in a common action on the financial negotiations Portugal was requesting. Saliabury said the Government

- - considered any financial dealing between us and Portugal a matter which oxclueirely concerned the two powers in question... I did not think . . that they negotiations could form the sabject of diplomatic commio ation between Her Majesty's Government and the German government. 1

Such an attitude, if allowed to continue, would soon make it possible for Englend to present a fait accompli before Germany could oven get a chance to present her esse. Consequently, von Bulow Immodiately telographed Hatzfoldt an outine of Germany's position in the affair. The sum and substance of this message was that willy-nilly Germany was going to get somothing out of the Portuguese situation. Bulor volled his materialiatio outlook very thinly whon ho wrote,

1. Marquess of Salisbury to V1scount Gough, June $21,1898, \underline{B}$. D., I, no. 67 . 
For us as woll as for England in this matter as in all colonial matters in general, it is an affair not so much of provablo rights, but of intereste and the power available for establishing these interests, if nood bo. ${ }^{1}$

His arguments went on to prove that although Germany lacked the assurance of naval strength that Fngland had to assure her of independent action, whe controlled the European balance in such a way that ahould make things extremely embarrassing for Bngland if that country refueed to allow Germany to push her way into the negotiations. Then, too, he indicated that Germany should be given some reciproolty for the apport he had given to England's Egyptian polioy. In fact, if Germany did not get much reciprocity, she might be made to appear the fool and the Government would lose prestige both at home and abroad. In thie event Germeny would be forced to act with energy. So It would be ohe aper for England to come along quietly and agree from the first. 2 Bulow was anxlous to commit Fingland as quickly as possible, for although Portugal had refused England's conditions for the loan on June 20th, he felt that the financial condition of

\footnotetext{
1. Bulon in Geriln to Hatzielat, June 22, 1898, Dagdale, E.T.S., op. c1t., III, 32; also G.‥, X́IV, 272. 272. 2. Bulor to Hatzfeldt, June 22, 1898, G.P., XIV,
} 
the Fortuguese government would soon force it to capitulate. 1 He did not want thi to happen before Gormany could get an opportunity to partiolpate in the negotiations. Then too, he was anxious becaue he felt that France was eager to gain somothing at this time from the Portuguese situation. In fact Bulow's anxiety over possible French interference extended until Angust, the last month of negotiations. 2 In spite of the German attitude--if not intimidetion--and in spite of a desire to consider Germen seneltiveness, Salisbury was fundamentally concerned that the Portuguese Fmpire should not break up if anything could be dono to save $1 t^{3}$ In fact, this was 34.

$$
\text { 1. Bulow to Hatzieldt, June 22, 1898, G.P. XIV, }
$$

2. Baron von Richthofen to Count Hatzfeldt, Auguet 12, 1898, Dagdale, E.T.S., ㅇ․ cit., III, 37.

3. Dugdale, Blanche, Arthur James Balfour, I, 266-7. Th1s fear of Prance Is gome whet amusing; Von Bulow himself created the situation. At the same time that Germany was sounding out Fngland in early June for the possibility of joint action on the Portuguese colonial question, Von Bulow was sounding out France to see if she would act jointly with Germany on the same question. Von Bulow to count Minister in Paris, June 18th, 1898, Dugdale, E.T.S., op. cit., III, 30-31. Th1s was to be a type of hedging in oase ingland would not cooperate. Henotaux, Foreign Minister in the Meline Ministry appeared to be interested. However, before anything conorete was accomplished the Meline Ministry resigned. It was succeeded by the Brisson Cabinet in which Delcasso was Forelgn Minister. Dolcasse definitely did not approve of anything resembling Franco-German collaboration. The "danger" of French "Interference" cessed. 
Salisbury's attitude throughout the Portuguese conversations and negotiations; while Germeny was interested in securing spoil, he was chiefly interested in not antagonizing Germany and yet not offending Portuguese susceptibilities.1 Brandenburg. expressing somewhat the Germen Viewpoint, concedes that Fngland had no desire to hasten the dissolution of the Portuguese Impire. 2 Hamman is of a gimilar view. ${ }^{3} \nabla_{0}$ Eckardstein, Hatzfeldt's agsistant in Iondon at the time of the negotiations, belieres that the whole situation was hypothetical.4 Bulow on the other hand gives indioation throughout his account of the negotiation that he was atrictly interested in what he could get out of the situation in a material way. 5 Portugal's susceptibilities and the possibility of conoluding a lasting understanding with Fngland were not considered. He probably considered buccanneering the colonies from the very first. ${ }^{6}$ Ironieally 267.

1. Dugdale, Blancho, Arthur James Bal lour, I, 2. Brandenburg, op. cit., p. $11 \%$.

3. Hammany, op. cit., p. 83 .

4. Eokardstein, op. cit., p. 182.

5. Bulow, ㅇp 오t., I, $320 \mathrm{ff}$.

6. Garvin, op. cit., III, 321. 
onough the German Government through Bulor maintained a policy that was most acolnotly expressed by Sal1sbury in apeech in Albert Hall, May 4, 1898. He said then,

You may roughly divide the nations of the world as the living and dying... the weak states are becoming weaker, the strong states are becoming stronger . . the living will gradualy enoroach on the territory of the dying . . I

Germeny, wh her colonial appetite brought into full spate by the Weltpolitik philosophy, was evidently resolved to have her share of the world oven if she had to take it from the dying and give them a little help in the process of dying.

Portugal was made all too cognizant of her predicament, not only by the anstere paternalism of England, but also by the blunt diplomacy of Germany. On June 22, 1898 the British Government was Informed by soveral that the Kaiser had sent the King of Portugal such an argent message that the King had to rush back to Iisbon and grent an audience to the German Minister (Tattenbach).2 Tattenbach said that the Kalser could not continue on amicable terms with Portugal if the negotiations for a loan from England

\footnotetext{
1. Garvin, op. cIt., III, 28I.

2. Salisbury to Sir H. MacDonell, June 22, 1898 , B.D., I, No. 68 .
} 
wore continued without due regard to the legitimate interests of Germany. At this time the Portuguese Government was atill anxiously trying to get the best deal it could from England without unduly offonding Germany and France.1

The Portuguese government asked England what to do in reference to the German pressure. England informed Portugal that it depended on how bady she wanted the money. Howerer, ingofar as the intimidetion was conoerned, Salisbury sald that Germany had no right to interfere with the negotiations that mere being discussed between Portugal and Bngland. In reply to the Portuguese inquiry at this time as to what was England's attitude toward the "Ancient treaties," England roplied that it was the same as that expressed in Iord Granvilio's note to the British Ambassador in reference to a simllar request in 1873.2 It should be observed, hoverer, that the 1873 note made no mention of colonial territory. On the whole, the English attitude in the reply to Soveral's inquiries seomed slightly 0001 . The next day salisbary seomed to be a little

\footnotetext{
1. SQIigbury to Sir. H. MadonelI, Jane 29, 1898 , B.D., I, No. 71 . 2. Supra, Ch. I, p. 16 .
} 
more receptive toward German suggestions for a joint loan based on colonial revenues and on altimate possibility of assuring sovereignty of allotted colonies if the Portuguese should default on these Ioans. 1 Soreral approached Saliabury again on the twenty-ninth with a suggestion that $8,000,000$ pounds be lent to Portugal, 2,000,000 of which would be weoured by revenues from Mozambique; 6,000,000 of which would be secured by oustoms from Portugal itself. Sallsbury intimatod "that the adrantage to us ald not appear to be very great." 2 There was a definite attitude of reservation here.

By June 30th, Mr. Bertie, Assistant Undersecretary for Foreign Affairs, had prepared an official memandum based "on the assumption that Hex Majesty's Goverment are disposed to admit the participation of Germany, bat to exclude that of France in the arrangements for the relief of Portugal from her present embarrasements . . ." He concluded his comments with the ominous promise, atating:

If for political reasons it is necessary to come to terms with Germany we might have with her 150. 71.

1. Sal18bary to V18count Gough, B.D., I, No. 10 . 2. Salisbury to Sir H. HacDonell, B.D., I, 
an exchange of secret notes undertaking that whenever, if ever, the break-up of Portugal from internal calses should come about Germany shall receite certain specifled portions of the spoil. 1

This was the essence of the entire agreement concluded in August.

On July 6, according to Hatzfeldt, Salisbury himself began disoussion on the Portuguese question and assured him "that he was by no means refusing to come to an understanding with us on it." 2 There is no record of this conversation in the British Docamente. In fact, there is no record in any of the Foreign Office Archives. 3 By July 9, Salisbury was discussing specifics with Hatzfoldt. With no violont objections be listened to Hatzfoldt's suggestions of probable lines of division and distribution of shares of the Portugue se African Empire. He said, "I told Count Hatzfeldt I would place the negotiations before my colleagues on Tuesday." However, he still

1. Hemorandum by $M r$. Bertio, June 30, 1898, B.D. , I, No. 72.

2. Hatzfeldt to German Foreign office, July 6 , 1898 (cipher telegram), G.P.., XIV, 281.

3. Editor's Note, B.D.., I, 55 .

4. Salisbury to Viscount Gough, July 9, 1898, B. D., I, No. 74 . 
impressed upon Hatzfeldt that he could not, for fear of French mischief-making, consent to an agreement which would have the effect of wounding the feelings of the Portuguese, and giving them the impression that the English were watching for the downfall of Portugal. In the same statement in whioh he said that he would present the matter officially to his cabinet he still voiced his reluctance to sell an old friend into bondage. He said, "The difficulty will be a form of note which would not look like cutting up Portugal while otill alive."I However, he was now speaking of a note as a foregone conolusion. The die was cast. An agreement was ultimately to be made by two external parties--Germany and Britain--for the possible ultimate division between them of a third party's insecure colonial possessions, the Portuguese colonies. Based on surface indication anch an arrangement could beat be deacribed by Sir Arthur Nicholson, First Iord Carnock's statement. He desoribed it as "the most oynical business in my whole experienoe of diplomacy." Al ready by July 6, 1898

\footnotetext{
1. Salisbury to viscount Gough, July 9, 1898, B.. .., I, NO. 74 .

2. Nicholson, op. it., p. 285.
} 
Fingland had, according to surfaco indications, left considerations of Portugal aside. No reply was mado to Portugal's final capitulation to Salisbury's terms for a loan. I These terms would have given England-independent of German collaboration--a voice in the administration of Delagoa Bay.

By July 1898, then, Great Britain despite her ancient friendehip for Portugal and despite qualms of conscience was ready to make a deal to share in the eventual spoils of her decadent friend's Bmpire. England, to be sure, was not entirely to blame, because Portugal made the firat overture earlier in the year to raise a loan, seoured, if there was no other recourse, by the colonial revenues or possible sale. Nevertholess, Portugal did not intend to sacrifice soverelgnty over the colonies as the contemplated Anglo-Germen deal contemplated at this time. ${ }^{2}$ Heither did Bngland initiate the foint Gorman-English negotiation. Why then, notwithstanding Salisbury's qualme, did Fngland finally agree to negotiate? This question can not be fully answered at this state of discussion,

\footnotetext{
1. Sir H. MacDonell to the Marquess of Salisbury, Julg 6, 1898, B.D.. I, No. 73.

2. Sal1sbury to Sir H. MaoDonell, Jano 28, 1898, B.D. , I, No. 68 .
} 
but the fundamentel difference between the German and English viewpoint must be noted. Germeny was considering an immedate dissolution of Portugal. Englond was hoping for her to continue as long as posgible as she was. As long as Portugal stood-weak or strong-what Germany planned could not occur. England probably was using an uncertain possibility of an eventuality as a basis of negotiation with Germany to hold Germany in check. Germany considered that such a possibility could be made quite kinetic by a willful Germany acting in conjunction with Fngland. Fngland maintained an attitude of reluctance and hesitanoy. Germany maintained an attitude of opportunigm and action. Then, too, it should bo noted that as late as July 13, Saliabury seemed to think that Portugal would be a member of the negotiations. I As the negotiations developed he saw that Portugal was to be excluded. This fact probably contributed to his dislike of the whole arrangement, which he more or less tried to side-step. From the evidence already displayed it can

B. SaIfobury to Viscount Gough, JuIJ I3, I898,
I, I0. 75 . 
72

be said then that England finally agreed to such a paradoxical arrangement for political reasons, but she was always anxious that such an arrangement should not appear to be "cutting up Portugal while still al1ve." 


\section{CHAPTER IV}

THE ANGLO-GERMAN TREATY OP 1898 


\section{THE ANGLO-GERMAN TREATY OF 1898}

The colonial understanding only tentatively discussed before July 1898, now (July 1898) began to be more definite. Aotive negotiations took the place of suggestions and hints. Once England agreed to consider a settlement, the negotiations became merely protracted bargaining over who should eventually get what share of the Portuguese colonies. The outcome of this bargaining had two distinctly different aspects. On paper it would seem that Germany secured the "lion's share." Aotually England won a brilliant diplomatio victory at a tim when such a victory was politically and militarily pricoless.

Germany first demanded all of Angola (Portuguese West Africa) and all of Mozambique north of the Zambezi River and east of the Shire River. This inoluded part of what was already finglish territory, Blantyre. In addition to this Germeny desired the Portaguese island of Timor in the orient.

Salisbury was sure that the Kaiser was "bent on an agreement of some kind; but that, nevertheless, he was taking the opportunity to make larger demands 
than he was prepared to press."I As long as Salisbury took part in the negotiations he maintained, in addition to his concern about "outting up Portugal alive," an unrelenting campalgn to deflate the German demands to as low a point as possible. In fact, the Kaiser became so exasperated at Saligbury's attitude that he had his mother write her mother, Queen Victoria, informing her that her Prime Minister was on obstacle to the understanding between England and Germany.2

Whon Hatzfeldt returned to the Foreign Office on July 13 to see how his proposals of the ninth had been accepted by Salisbury's colleagues, he found that a definite decision to consider negotiations had been made. 3 However, the terme that salisbury placed before Hatzfeldt left him 1ll-satisfied. At this stage of the negotiations Salisbury still assumed that portugal would have a voice in the decisions. To all appearances he was going on the assumption that Portugal gtill wanted money badly

\footnotetext{
1. Salisbury to V1scount Gough, July 9, 1898, B.D. . II, NO. 74 .

2. Ianger, op. c1t., II, 527 .

3. Sallsbury to Viscount Gough, July 13, 1898, B.D. . I, No. 75 .
} 
enough to be agreeable to a joint loan instead of one to England alone. England's counter proposals gave Germany anbstantially what she wanted in Mozambique, but only that portion of Angola south of the torm of Egito.l England also wanted as a sine qua non that Germany agree to Portugal's abendoning to England the railroad from Lorenzo Marques as well as the port 1tself. Salisbury still insiated that Portugal and her colonies should be maintained as long as possible and that no surrender of sovereignty be involved in the loans. He suggested that preemptive rights be granted over those section used as collateral respectively for Germany and England. These preemptive rights were to go into effect only if mischance overtook Portugal to such an extent that she would be forced of her own accord to surrender her colonies. Iate on the came afternoon that saliabury informod Hatzfeldt that England was agreeable to a joint loan along the lines just described, the Portuguese Minister Marquis de Soveral called on Sal isbury and delivered the following message: $"$. . In view of all the difficulties with which the question of 
a Io an was surrounded, his Government had decided in favour of leaving matters in statn quo." l According to salisbury, soveral explainod that this decision involved the abandonment of all idea of a loan from the British or any other Government and also of ang notion of altering the attitude of Groat Britain or of Portugal towards any portion of the Portuguese possessions in Africa. This point-blank statement put a decidedy different interpretation on any further negotiation that might be oarried on, for now the negotiation would not inelude participation of the subject of the negotiations, Portugal. Portugal's refusal "to come along" was extremely embarrassing because her procarlous finances might oven have initiated an international comission of debt administration, which, of course, would have precluded any diplomatic or colonial schemes that either Fngland or Germany might have. Nevertheless, the negotiations continued without the blessing of portugal's presence or acquiescence. On JuIg 19, 1898 Hatzfelat again called on Selisbury and expressed terms for an agreement

\footnotetext{
1. Salisbury to Sir H. KacDonell, July 13 , 1898 , …… I, No. 76 .
} 
which were very similar to those of July 9; he presented these in French in the tentative form of a treaty. 1 The next day Salisbury informod Hatzfeldt that the cabinet had fully considered the proposals and found that they were not ontirely acceptable. ${ }^{2}$ Above all things the British would not give up certain territory of their own as well as the Portuguese territory. The Germans had proposed to allow Fngland to have the unrestricted right to control Delagoa Bay and the Trangraal Bay in return for Blantyre (British territory), most of Mozambique, Angola and Valfiach Bay (British territory). Saliobury explained that England already had preemptive rights over Delagoa Bay, 3 hence Germany had no legal right to objeot before international lew if England were to acquire this area independent of German cooperation. The Britioh Prime Minister countered the German bid for Britioh territory by a demand by England for Togoland, if Walfisch Bay wero to be given up. This upset the German Ambassador

1. Sellgbury to V1scount Gough, July 19, 1898, B.D. . I, No. 77 .

2. Salisbury to V1scount Gough, July 20, 1898, B.D., I, No. 78 .

3. Supra, Ch. I, pp. 17-18. 
Immonaely. He even threatened that Germany would have to turn to Russia if England would not give more conorete indications of a desire to become a Irlend of Germany. Apparently Saliobury as a "mater of public affairs" was trying to eludo Hatzfoldt as long as possible by various evasions.1 on the other hond it was apparent that Gormany considered herself in an exoellent position to arire a good bargain. The negotiationg continued for almost a month longer with Germany and England remaining at these two extremes. The tenor of the German negotiations in this affalr as desoribed in the subsequent memoirs of the principle negotiations, is oxceodingly mild in comparison to that expressed in the documents. Von Bulow's very general account of the episode would make it seem to be merely a trial of British fidelity which the treaty found to be lacking. 2 This riewpoint, however, is rery easy to arrive at years after all of the erents in the situation had taken the course desting had deslgned. Eokardstein states that the negotiation were very hypothetical. 3 However, at the

1. Guedes, op. o1t., p. 32\%.

2. Bulow, op. c1t., III, 320-321.

3. Eckardstein, op. c1t., p. 182 . 
time of negotiation it was evident that Germany was thinking in terms of definite objectives whioh could be obtained because of the financial embarrassment of Portugal and diplomatio embarrassment of Fngland.

Between the twentieth of Julg and the twontyseventh, no official British records were made on the negotiations. On the twenty-geventh, the indomitable Hatzfoldt again appeared at the Forelgn Office to see if Fingland was still willing to oonolude a treaty with Germany in referenoe to the Portuguese colonies. 1 Evidently when Berlin learned that the threat to appeal to Fngland's old onemy, Russia, did not make Britain jump into Germany's arms, the Reich was willing to make a fow concessions. Germany no longer brought in the extraneous matter of cession of British territory contiguous to cortain Portuguese colonial areas allotted by Germany to Germany. The demands for Blantyre and Walfisch Bay were dropped as were (temporarily) the demands for Timor. However, in return for thi conceasion Germany wanted more territory in Angola and Mozambique which formed an enclate into British territory. Salisbury immediately stated

No. 79 . 
that this was not agreoable. These views were roiterated a week later when Hatzfoldt again reviowod the conversations. ${ }^{1}$ selisbury repeated his objections of Julg 27; whereupon Hatzfeldt suggested that in return for giving up demand for the enclaved territory between the Zambezi and Shire Rivers, Germany should recelve more land in Angola. Salisbury again countered with objections. First, he objected to the term "compensation" used by Hatzfeldt in reference to concessions Germany wanted in Portuguese Africa from England in return to concessions given to her. Then he indicated that the added territory Germany wanted in Angola would require that Fngland at least be granted extra-territorial rights there in case of an eventual portuguese oession.

Salisbury still was anxious to consider the susceptibilities of Portugal. He otill gave the impression that Portugal should be consulted and informed. He stated that if the arrangement were made between England and Germeny "a great deal of drafting would be necessary in order to prevent such stipulations from wounding the feelings or infringing 110. 80 .

$$
\text { 1. Salisbury to Sir F. Lascelles, B.D., I, }
$$


upon the rights of Portugel." I He did not yot seem to think a seoret arrangement was necessary.

Hatzfeldt himself gave the best description of the Prime Minister's reactions when he said "I realized that the Prime Miniater wishes at all costs not to appear at Iisbon in the l1ght of an expectant hoir, dividing in advance the Portuguese heritage with another."2 Perhaps it was more than a coincidenoe that at this particular point in the negotiations Saliabury decided to take a rest at his French villa at Dieppe. After August 10 he had turned all of the negotiations over to his nephew, Arthur Balfour, whom he left in charge of the Foreign Office. 3 Balfour spent the next ton days in cutting down the extraordinary German demands so that an agreement could be reached.4 It is quite possible that between JuIy 20 , 1898 when Salisbury was so cold to Hatzfeldt's suggestion and August 3 when he appeared reconciled to an agreement of some sort, pert of his mixed

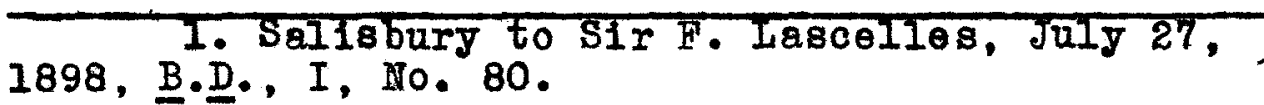

2. Hatzfeldt to German Foreign Office, August 8 , 1898, Dugdale, E.T.S., op. oit., III, 36.

3. Dugdale, Blanche, op. c1t., III, 267. 4. Ibid. , p. 267 . 
81

cabinet had indicated a desire to make a deal involving possible infringement of Portuguese sovereignty. This be agreod to because of political reasons, although he did not approve personeliy. Then, too, he never relished the idea of an alliance or agreoment with Germany. The Chamberlain element was particalarly desirous of an arrangement of friendship with Germany. This had, of course, been attempted earlier in the jear by Chamberlain without enthusiastic support from Salisbury--who oddy enough was taking a short rest in France at that time too. The French Foreign Office is responsible for a similar interpretation, in reporting the situation from the viewpoint of the Marquis de soveral of Portugal. ${ }^{1}$ The Quai D'Orsay had the impression that when Salisbury realized that portugal would have to pay the piper for the realization of an agreement of sorts with Germany he "retired to his ville at Dieppe to aroid recrimination of the Marquis de Soveral--afin d'eriter les recriminations de M de Soveral, le Marquis de Salisbury se rendit dans se villa de Dieppe. "2 This

1. M Defleurian, Charge D'Affaires de Franco a Londres a $\mathrm{M}$. Poincare, Ministre des Affaires Etrangeres, Londres, 2 Ávril 1912, Documents Diplomatiques Francais 1871-1914, 3 Serie 1911-1914. Tome Second, 8 Fevrier, 10 MaI 1912, No. 291, p. 297. 2. Ibid., p. 297. 
document states that Salisbury had defended himself but poorly wen Soveral addressed observations of righteous indignation to him. There is no specific record of such a conversation in the British Docamente. The Portuguese writer, Guedes, gives the impression that Soveral might have spoken to Salisbury about the pending Anglo-Germen deal. 1 However, Guedes bases some of his information on the French documents and consequently, cannot be relied upon as a completely independent source--especially since there was no official Portuguese documents publishod on this entire episode.2 Brandenburg gires the

\section{Guedes, op. cit., pp. 327 If. \\ 2. In a letter sent to the writer of this} thesis on November 27, 1941, by Pedro don de Souse Pernes, Attache to the Portuguese Legation in Washington, D. C. the following information on Portuguese material for this thesis was given:

"The Minister has asked me to thank you for your letter of November 22nd, and to tell you that there has been no official 'White Book' publighed by the Portuguese Government on the subject of 'The Anglo-German Negotiations over the Portuguese Colonies 1898-1914.'

If you read Portuguese you may find something of interest in the book, "A Alianca Inglesa" by Armando Marques Guedes, published in Ilebon, 1938, pages 324-27 ...

Other references of interest con be found in Mr. Harold Nicholson's biography of his father, Iord carnock. In this book you will find quotations which show the attitude of the British Foreign Office in regard to this whole question." 
Impression that Salisbury wanted to wash his hands of the whole matter; ${ }^{1}$ hence, the delegation of the task to his nephow. Then, too, Salisbury had eraded Germany as much as possible. Then he finally sam that Germany could not be put off any longer he may have let someone else take the onus of responsibllity and have given assurances in the meantime to the proteating Soveral. Iater in 1911 the Ambassador to France, Sir Francis Bertie, wrote S1r Edward Grey the following interpretation of Salisbury's absenoe: (Bertie was Assistant Under Secretary of State in 1898.)

- the negotiations had been begun by Iord Salisbury, who later on told Count Hatrfeldt, so the latter informed me, that he would not have signed the Agreement, to which the Ambassador retorted, so he said to me, that ho (Lord salisbury) certainly would have signed it for the Cabinet would have made him do so.

Iord salisbury had no affoction for the Agreement, but that was, I think, partig because he had hoped to stave off the German Government and thought that his nophow had been too ready to conclude the negotiations. Besides this, in the latter days of Iord Salisbury's time as Secretary of Foreign Affairs, he and Arthur Balfour were not always at one and the uncle was rather jealous of the nephow in his mariagement of the Foreign Office during the uncle's absence. 2

\footnotetext{
1. Brandonburg, op. cit., p. 115.

2. Editorial note quoting a memorandum in Grey's Mss., Vol. 54, January 25, 1911, B.D., X, Pt. 2, No.268.
} 
Bulow reports that Salisbury mado a simflar excuse to Hatzfeldt oomowhat after the agreement had been concluded. 1

Nevertheless, the fact remains that soon after Salisbury's sidestepping of the 1ssues, a treaty was concluded between Germany and England. When Balfour assumod control, the Assistant Under-secretary for Foreign Affairs, abmitted a momorandum to him to acquaint him with the salient British considerations. In this note he still implied that the British consent to negotiations was based on the hypothesis "that the Portuguese Government will be willing to socept the cooperation of Germany with England in providing money for Portugal, she giving in return reversionary rights over Portuguese territories to Germany and England." This was the Salisbury standpoint. The Memorandum continued with some observations that might explain Saliabury's previous evasiveness to Hatzfeldt:

There are no indications that the cooperation of Germany with England would be acceptable to Portugal. On the contrary, she is well aware of the territorial and financial design of Germany, and it will only be very great pressure and dire financial necessity that will bring her to submit to the intervention of Germany in her affairs. M. de Soreral is strongly opposed to $1 t$, and urges that wo should not tio our hands with Germany as 
if we can postpone the question till the autumn--when we may be less ocoupied elsewhere-there is good prospect of a change of government at Iisbon and a satisfactory settlement botween England and Portugal. I

Here is at best indirect evidence of the conversation between soveral and Salisbury referred to in the French Documents. 2 This also explains much of England's conduct in the Anglo-German-Portuguese matter after the proposed agreement became an actuality. It possibly explains why Fingland hesitated and why the troaty that was finaliy made did not go into effect. Nerertheless, Balfour, having a spocific situation before him--an anxioug Gormany clamoring for an agreement which oome of the Britigh cabinet had 10 on hoped for in one form or another--proceeded with negotiations in a most direct manner. It would almost seem that he had this one particular task to do. Perhaps it had been delegated to him by his unole specifically. However, it would be hard to furnish a satisfactory explanation of such a surmise. Subsequent erents show some generalized reasons. Evidently the Bertio Nemorandum and all of its cautions and doubts did not deter Balfour. The Memorandum seems to

\footnotetext{
1. Kemorandum by $M r$. Bertio, August 10, 1898, B.D... I, No. 81 .$$
\text { 2. Supra, p. } 81 \text {. }
$$ 
summarize the situation up to the point where a decision was made to agree with fermany, bat does not include reference to a definite decision to sign.

Al though Germany did not like to ohange horses in mid-stream, she felt that there might be some advantages. Hatzfeldt presents the situation as follows:

Although the delay caused by handing over further negotiations to $\mathrm{Mr}$. Balfour is undesirable, jet I think we must consent to it. The last time he represented Iord Salisbury, Mr. Balfour was honest and fortheoming towards us; when we come to discuss the matter with him it will probably be soon evident whether a quicker conclusion is to be expected in this way. Iord Salisbury says that Nr. Balfour will probably start disousing the matter by next Wednesday. 1

On August 11 the German Ambassador oalled upon Balfour in reference to the portuguese matter. Balfour exprossed a reluctanoo--similar to his ancle's--about dismembering Portugal before she wa's dead. 2 He pointed out that England was willing to lend money to Portugal only to keep her alive. The colonial areas designated as collateral were only to be designated as a proviaion for the eventuality which the proposed treaty and loan

\footnotetext{
1. Count Hatzleldt to the Gorman For ign ofilce, August 8, 1898, Dugdale, E.T.S., 으. cit., III, 36. 2. Mr. Balfour to Sir F. Lascelles, Auguat 11, 1898 , B. . ., I, No. 82 .
} 
should seek to avold. However, provisions were me on both sides as to the probable disposition between them of the Portuguese colonies, in case of such eventualities. Hatzfeldt handed Balfour a memorandum as an unoffioial comunication. It was a slight amplification on the one he presented to Salisbury on the Third of July. On the eighteenth, the German Ambassador had another interviow with Balfour. Balfour informed Hatafeldt that according to his understanding with his unole, Timor was not to be incladed in the proposed arrangement. 1 This displeased Hatzfoldt who intimated that if Timor were not ineluded, the negotiations would be broken off, with resulting hard feelings in Germany.

At this same meeting the acting Prime Minister presented the German Ambassador with two memoranda which were Fngland' a counter offer to Hatzfeldt's "Unofficiel Memorandum" of the eleventh.2 These Memoranda summed up what had been the previous British stand. The firet memorandum stated that if money were to be loaned to Portugal, it would be loaned jointly by the two powers, Fingland possibly taking the largest loan. These

\footnotetext{
1. Balfour to Sir F. Lascellos, Augugt 18, 1898, B.D. . I, No. 83 .

2. Ibid., Enclosures 1 and 2 .
} 
prospoctive loans were to be secured by revenue from Portuguese colonies so distributed that Germany would have the largest and Fngland what was the most strategic. This security would not entail a saerifico of sovereignty. These territorial distributions were about the same as those which England had demanded up to this date.

The second Hemorandum (B) provided for the action Germany and England should take if the integrity of Portuguese possessions could not be maintained. The two powerg would take over the areas which they had allotted to each other merely a loan security if Portugal could not maintain her integrity. England was to get two small trading areas in the area of Angola designated for. Germany. Nothing in the Declaration was to detract from any understanding already in effect between Portugal and England. England wanted to retain the advantages of her alliance with Portugal until the very moment portugal would fall. Timor was not mentioned in either Memoranda. The next day the Ambassador from Berlin informed Balfour that Timor was an absolute "must" for the negotiations. I By now the negotiations had proceeded to a

I. Balfour to SIr F. Lascelles, August 19, 1898,
B. I, No. 85. 
point where Fingland was making defintte commitments. The Portuguese government suspected as much. In fact, Hatzfelat's frequent visits to the Foreign Office were a cause of extreme anxiety to de Soveral. He called on Balfour and stated that he feared these frequent conferences boded no good to Portugal. 1 Balfour told him that he was sure Portugal know from Sallsbury of the deoision of England to act in unison With Germany. Soveral replied to the contrary. Hie understanding was that Great Britain would firet come to an understanding with Portugal and then possibly invite Germany to share the loan and its collateral. This was an ombarrassing presentation of the matter to England because at that particalar time Portugal had made no bana fide application for a loan. In fact, she had withdrawn her application over a month before, on July $13 .^{2}$ Balfour told the Portaguese representative that even though there was no current application by Portugal, it would be for the best of all concerned for England and Germeny to come to an agreement at once. There were, he said, only three possible courses of action for Portugal.

\footnotetext{
1. Balfour to Mr. Thornton, Augast 18, 1898, B.D. , I, No. 84 .

2. Supra, Ch. IV, pp. 74-75.
} 
The first was to borrow from Great Britain alone, as he had apparently desired; the second was to borrow from Great Britain and Germany together, acoording to the proposal which I had just sketched out to him; and the third was to endeavour to borrow from other Powers, which would probebly only be done at the cost of an international control, to which we should have the strongest objection, and whioh would be disastrous to the independence of his country. If for any reason therefore the first of these courses seemed to us inexpedient, the second was the one most advantageous to portugal. I told him frankly, therefore, that though I could not say whether our negotiations with Germany would be successful, I should endearour to make them 80.1

This was putting the matter bluntly. But at least Soveral knew what was going on. Balfour did promise to "oommanicate with him again, if and won, anything was finally arranged with Germany. "2

on the twentieth of July Balfour informed

Hatzfeldt that he and Bertie agreed that Timor could be included in the German share of the collateral. 3 He also suggested that the treaty could be swallowed much more easily by Portugal if the interest rate on the antioipated loan were kept very low. On the whole Hatzfeldt seemed very happy. The agreement was about

\footnotetext{
1. Mr. Balfour to $\mathrm{Nr}$. Thornton, August 18, 1898, B.D.. I, No. 84 .

2. Ibia., No. 84 .

3. Mr. Balfour to Sir F. Iascelles, August II, 1898 , B. D., I, No. 82.
} 
to be concluded. He telegraphed the German Foreign Office the following message:

Timor is settled, and I am convinced that we owe it to $\mathrm{Mr}$. Balfour alone, for he urgently desires a conclusion. I beg therefore that as fow difficulties as possible be made for him regarding his draft, and that a secret note in explanation of the affair be agreed to in the manner I recommended. I

In conceding Timor, Balfour had to "battle down" Chamberlain, who never wanted to see another power improve its colonial position more than fingland regardless of the circumstances. 2 When Balfour and Hatzfeldt next conferred all seomed smoothly settlod. 3 It wes agreed that Germany would be given some compensation similar to Delagoa Bay if Bngland should ever exercise her preemptive rights there. Germany deomed this neoessary to placate public opinion. However, Balfour pointed out that the noed for an action requiring compensation for Germany would only occur if Portugal collapsed completely--beyond the extent of help that a loan could offer. Although it was agreed to give Germany

1. Count Hatafeldt to the German Foreign office, August 20, 1898, Dugdalo, E.T.S., op. c1t., III, 38.

2. Dugdale, Blanohe, 오. cit., III, $268 \mathrm{ff}$.

3. Mr. Balfour to Sir F. Iascelles, August 22, 1898 , B.. ., I, No. 88 . 
preemptive rights over Timor, England declined a German suggestion that England be given in return the surrender of German extra-territorial rights in Zanzibar. This refusel was based on Balfour's desire not to give the impression that Fngland and Germany contemplated and desired the eventuality of the proposed agreoment, that is, the sharing of the spoils of a fallen Portugue se Impire. If Fingland had agreod to accept compensation for giving Germany oventual preemption of Timor, it would have looked as if the two powers were more bent on dividing Portugal than helping her with a loan. Here again the difference of the German and English opinion of the treaty can be observed. England wanted to postpone the eventuality; Germany wanted to hasten it.

A fow more minor suggestions were made at this conference by both parties. All that remained to be done now was to wite up the final draft of the treaty. This was done, and on August 28, Salisbury gave his approval of the arrangement after the drafts had been sent to him at Dieppe. He said:

I am afraid the German negotiations mat have given you a great deal of trouble. If the Germans take to being punctilious they are quite intolerable. The result seems to me quite satisfactorg.l

1. Dugdale, Blanche, op. cit., III, 272 . 
However, he still indicated his reluctance on August 30 , when he replied to Balfour's message informing him that the agreement had been signed. He said, "I only hope that it will not come into use for a long time." I

When the agreement had been signed the Kaiser telegraphed Bulow the following message, showing the leit motif of the German viewpoint:

I am rery glad of this turn which is all the more important since the peace and disarmament proposals and all the chatter about them add not a Iittle to the prospects of war. I thank you, dear Bulow, for your devoted and successful labours, and for the ability with which you have induced Britain at last to give way to us. This is one more great triumph of your diplomatio adroitness and farsightedness.2

The agreement--officlally it was not a treaty but a "note"--was signed jointly in Iondon, August 30, 1898, by Balfour and Hatzfeldt. 3 The agreement provided that whenevor it was deemed expedient by both Germany and Britain to accede to a reguest for an adrance of money, the loan was to be made simultaneously. The amount to be assumed by oach would be decided at the time of lending. The territory was so

1. Dugdale, Blanche, op. cit., III, 272.

2. Bulow, ap. cit., I, 321.

3. See Appendix A, B and C. 
divided that Germany would be ellowed to take Timor, all of Mozambique north of the zambezi below its confluenoe with the shire, and the greater part of Angola; England would be allowed to take the remainder of Mozambique and Angola. I If a foreclosure of the proposed loan were necessary delegates would be sent to Portugal to inspect the revenues. However, no rights of administration were to be given to these inspectors. Administration of the revenues was to be undertaken only if Portugal defaulted.

To all appearances this was a rather logical agreement even if Portugal were not allowed a voloe in its arrangement. The agreement took cognizance of Portugal's sovereignty and ostensibly would not have gone into effect unless Portugal requested a loan of her own volition. Fingland did not hesitate to give this part of the agreement wide publicity, a fact which irritated Germany tremendously. 2 Now the Reich could not object to English action in South Afrioa. However, what Englend did not publish was the appended secret agreement which provided for the exclusion of third perties from intervening in Portuguese

1. Se日 map, Appendix F.

2. Bulow to Count Hatzfeldt, September 3, 1898, Dugdale, E.T.S., op. cit., III, 39. 
colonies included in the Anglo-German loan agreement, matual abstinence from any future claim to those portions of the Portuguese empire allotted to each as security, and assamption of complete control by Germany and Ingland of those parts of the Portuguese ompire allotted to each if Portugal over for any reason renounced her sovereigh rights. ${ }^{1}$

This section could be rery dangerous to Portugal's integrity. In violation of the "ancient" treaties, Portugal was never formally told about the Anglo-German negotiation, notwithstanding Balfour's promise of Auguat 18, 1898. He merely informed Soveral of the firgt part of the treaty in which there was no indication of a provision for the possible loss of sovereignty by Portugal. However, Lord Edward Grey stated in 1925: "do Soveral knew all about the secret agreement with Germany 'and made no secret to Iord Sallebury of his knowledge of 1t.'" On September 2, 1898, Salisbury took over again. His lack of enthusiasm for the agreement was noted imodiately in his hesitation and reluctanoe to force a loan on Portugal.

The Anglo-German agreement of 1898 was signed

1. Newton, A. F., A Hundred Years of the British Empire, p. $36 \%$. 
on Augast 31, 1898. On September 1, 1898 Hatrfeldt was already at the Foreign Office attempting to impress on Balfour the possibility of the Portuguese accepting French loan. Hatzfeldt regarded this as extremely probable aince Portugal was not apprised of the secret clauses in the new convention which precluded participation in a loan to Portugal by any power other than England and Germany. He recommonded immodiate activation of the purpose of the treaty. Balfour recites the Hatzfeldt presentation of the case as follows:

The German Ambassador called on me this afternoon in order to speak to me about a possiblo complioation which might arise in connection with the recent Anglo-German Agreements. He pointed out the possibility of the Portuguese Government, in ignorance of its exact terms, going to France rather than to the two Powers for the purpose of obtaining a loan upon the security of the customs in her African Colonies. Such a transaction might be concluded before we knew anything about 1t; but inasmuch as, under the Anglo-German Agreements, the two countries would be bound to resist French intervention, by foroe if necessary, it was manifest that all four Powers might find themselves unawares involved in the gravest oomplications.

All this might be avoided if it was known beforehand--at all exents by the Portuguese Government--that we could not admit the intervention in the matter of a third Power and that we were prepared to give every facility ourselves to the raising of the necessary loan. 1

1898 Mr. Balfour to Sir f. Lascelies, September $I_{1}$ 1898 , B...., I, No. 94. 
Hatzfoldt urged action by Germany and her oosigner, Rngland, before October, the time when he ourmised that the French loan might materialize. Balfour promised to refer the matter to Salisbury who was to resume control at the Foreign offloe. A minute added by Salisbury to the above communication gives striking illustration of his personal views as well as the future policy and attitude of fngland in connection with this treaty. Selisbury wrote:

I expected this. They are not content to wait for events to give them their share of Portuguese territory, but wish to force the pace of deatiny. I do not think that it is possible to make such an intimation to Portugal till we know of the sort of finanoial terms Germany is disposed to give. They will be of the shylock school.

There is no real danger to us--free right of preemption protects the East Coast: and our ownership of the hinterland protects Ioanda. ${ }^{1}$

On September 9, 1898 Salisbury wrote Lascelles that he had instruoted the Assiatant Under-secretary to tell Hatzfelat "that, in my opinion, M. de soveral being already aoquainted with the general purport of the Anglo-German Agreement, it would be sufficient that I should intimate to him that any loan from France must not be secured on the customs of Angola, and that

\footnotetext{
1. Hr. Balfour to Sir F. Lagoellos, September I, 1898, B.D.., I, No. 94, p. 76 .
} 
warning I would convey to him."I Fngland continued to give Germany such vague as surances. Despite these assurances, however, Salisbury wrote the followlng letter to Sir H. MacDonell in Lisbon on November 7 :

The Portuguese Minister callod at this office on the 5th Instant and made, for my information, a communication respecting the loan for which the Portuguese Government are negotiating in Paris. . .

I have expressed to M. de Soveral generaliy my satisfaction at the statement made by him on the part of the Portuguese Government in regard to the loan which they seek to raiso in Par1s, and I have stated to him that, under the limitations which he had mentioned, the finanoial measures taken by Portugal for dealing with hor oreditors are a matter entirely for her own decision.?

This was definitely not the German viewpoint. As early as October 1898, without active or stout cooperation of England, Germany was attempting to force Portugal to accept a loan based on the revenues of her colonies. 3 Tattenbach, the German Minister, tried again and again to get British support in his efforts to force Portugal to accept a loan.4 The German Government's conoept of the agreoment was ell too clearly indicated by their

1. Salisbury to Sir F. Iascelles, september 9, 1898, B.D., I, No. 97.,

2. Salisbury to Sir H. MacDonell, November 7, 1898, B.D., I, No. 100 .

3. Guedes, 오. e1t., p. 330 .

4. Ibid., p. 330 . 
attitude then, fust a short month after the signing of what Eckardstein called a "hypothetioal agreement."nl

Sir H. MacDonell, English Minister to Portugal, reported on July 22, 1899, the following resume of the situation in October 1898.

I may here observe that, on my return to Iisbon in Ootober last, I found Count Tattenbach had been pressing the Portuguese Ministers--perhaps unduly-to accept the good offices of our respectire Governments for the purpose of raising a loan; he then unreservedly admitted to me that he understood his instructions to convey that one of the objects of the Anglo-German Agreement was to induce the Portuguese Government to contract a loan in order that, when 1ts procoeds had been extravagantly wasted, we should remain with a claim on the control of the Portuguese Colonial Customs.

I promptly informed him that I had received no such instructions from jour Iordship, and that I hoped ho did not expect mo to follow him in that Iine of action.2

Despite German machinations to the contrary, the agreement never went into effect. Nor did Portugal find it necessary to borrow from the English, German or French Governments. The Portuguese debte were refinanced from money that was obtained by small temporary loans besed on home revenues at high rates of interest, and from the sale of large amounts of produce

\footnotetext{
1. Supre, Ch. IV, p. M.

2. Sir H. MacDonell to Marquess of Salisbury, July 22, 1899, B.D., I, No. 112.
} 
arriving from the colonies. 1 Private French banks raised moh of this money. 2

So it was then that by July 1899 , lass than a year after the completion of the agreement, Sir H. MacDonell could report that count Tattenbach, German Minister in Lisbon, had to admit that a marked improvement had taken place in the financial situation of Portugal and that the idea of a loan under the Anglo-German Agreement was definitely out of the question in any case for the time being. 3 The tedious dalliance of the British Foreign Office in making the agreement and then the studied delay in putting it into effect gives some substantiation to Bertie's statement that Salisbury wanted to put Germang off until October, when conditions would be better for England. 4

\footnotetext{
1. Sir H. MacDoneli to Marquess of Saligbury, Julg 22, 1899, B.D., I, No. 112 .

2. Garvin, op. cit., III, 319.

3. Sir H. MacDonell to Marquess of Salisbury, July 22, 1899, B.D., I, No. 112 .

4. Supra, Ch. IV, p. 83.
} 


\section{CHAP TER V}

THE ANGLO-PORTUGUESE TREATY OF 1899 OR THE SO-CAIIED "VINDSOR TREATY" 


\section{CHAPTER V}

THE ANGLO-PORTUGUESE TREATY OF 1899 OR THE SO-CALIED "TINDSOR TREATY"

By 1899 the apparently 180lated events of the "ancient treaties" between England and Portugal, the Boor situation, England's isolation, and the dormant Anglo-Gormen Portague colonial agreement began to show on interesting relation. This inter-relation becomes visible upon examination of the Anglo-Portaguese Declaration of 1899 erroneously known as "Treaty of Windsor." Investigation of the Anglo-Portuguese Treaty of 1899 show how England resolved the dilemme of keeping an old friend dospite the fact that sho had made a treaty designed for the eventual disposal of the old friend's possessions. Hever was the illogical metaphor of "having one's oake and eating it, too," moro literally executed. Out of an apparently impossible situation England secured advantages from both Germany and Portugal. To understand how the situation of 1899 was resolved, specialized recapitulation of the background in 1898 is necessary. Throughout the negotiations for the AngloGerman agreement of 1898 the pronounced reluctance and evident lack of enthusiesm of Ingland could be 
noticed. Yet it was politioally and diplomatically necessary for England to make the agreement with Germany. No one knew the character of this necessity more clearly then the German Government. The insight of the German Government into the question is very clearly explained by Hatzfoldt's demands to partiolpate in the Portugrese 1oan. These demands had much the same charactor as an ultimatom. Hatzfoldt's report of thi conversation with Selisbury on June 14 , 1898, If exact, shows a most adamant attitude. ${ }^{1}$ He said,

I explained in eriendly but emphatic terms that one-sided action in the matter hore, involring actual or contemplated passing of Portugal'a soverelgn rights in these colonies into Britioh hands, would make a very bad impression with us and also would not tend to improve our relations which we both desired, and that the question was a political one which he, salisbury, and not Chamberlain, wonld have to decide.'

Baron Holstein reported a similar version at the interview. 3 The Kaiser substantiates Hatzfeldt's account of pressure being brought to bear on England by his

\footnotetext{
1. Supra, Ch. III, p. 59.

2. Hatzfeldt to Foreign Office, June 14, 1898, Dagdale, B.T.S., op. o1t., III, 29; aiso G.P., XIV, 10. 267. The undersooring is mine.

3. Bulow, 오. e1t., II, 323.
} 
congratulatory message to Bulow. 1

Of course, part of the English Gorernment, led by Chamberlain, had made overtures to Germany earlier in 1898 for a possible alliance, only to meet a rebuff. Nevertholess, even the more hesitant element of the oabinet led by salisbary indicated that a rapprochement might still be dosirable. Consequently, England was on record as wanting some sort of an arrangement with Germany. In fact, the impendIng Boer holocaust and Fngland's lack of allies made such an agreoment imperative. Germany was well aware of England's predioament, hence her cool reception of Chamberlain's overtures. She was also well aware of her own colonial ambitions, as the reactions to the Jameson Raid so well 1llustrated. The necessity of Germany's backing down from her initial adamant attitude after the Jameson Raid also showed her Government, if not her poople, the Impossibility of eponsoring the Boers against a maritime power. This view had been all too woll understood by the German Admiral von Tirpitz. Despite his hatred of Ingland, ho condemned the official policy and anti-Engliah trond of German

1. Bulow, op. olt. II, bEI. For a fuII quotation of the $\mathrm{K}_{\mathrm{a}}$ ise $\mathrm{T}$ remarks to Hetzfeldt at this time seo Supra, Ch. IV, p. 93. 
pablic opinion at the time of the Jameson Raid. He belleved that both government and pablio opinion had an unrealistic view of Germany's strength ${ }^{1}-$-an argament which would, of oourse, sapport his demande for a larger floet.

Here was a dilemma for Germany: how could she secure land in South Africa and jet arold the danger of an Impossible war wh England? Realizing that championing the Boore' cause might bo strategioally wrong, in spite of the moral justification of sympathizing with these poople, Germany percelved that she showl bow out as eqsily a possible and yet make the best bargain that sho could for the good of the Reich and face-saving before German public opinion.

This appears to have boen in the minde of tho German politicians throughout the negotiations. It 1s a riew expressed oarly in the negotiations by Bulow:

In leaving the Fnglish a free hand regarding Delagoa Bay and its Hinterland we take $a$ step which F111 cause a feeling of disappointment amongst the whole German people beoause the Boers for years hare become the object of a sentimental eympathy which as in all cases of sympathy cannot be combated on ground of logic. Therefore, the Kaiser's Government, if it is not to suffer capitis diminutio, must bo in a position to show

$$
\text { 1. Tirpitz, A. Von, Mr Memoirs, pp. } 56 \text { If. }
$$


that its polioy has not merely made renunoiations but has gained evident advantages. I

England, also, realized her own predioament only too woll; bat sho was able to turn it into a diplomatic victory. She realized that she had to oign with Germany or else multiply her dificulties In South Africa and Europe at a time when the Boor question, as well as the Fashoda inoident, were approaching a climax. Sir Edward Grey expressed the situation as follows:

It seomed clear from what I saw in them [papers he absequently read on the situation] that the agreoment had been made very reluctantly so far as Lord Salisbury was concerned and only in deference to German insistence--pressure would hardly be too strong a word. Crudely put, the German insistence was this, "you [Britain] are on bad terms with Rusgia and on bad terms with

1. Bulow to Hatz feldt, June $22,1898, G . P .$, XIV, 274. This also proves that Gormany had Irom the very first resolved to get something conorete from the agreement. Hence to the German Government it was not as hypothetical as Eckardstein assumes in his Ten Years. (Eokardstein, op. olt., p. 182.) He, of co urrse, was explaining retrospectively according to the letter of the agreement and not the spirit of the Germen Government's interpretation of the agreement. Even before this statement was made on the 22nd, Bulow wrote to Hatzfeldt on the 8th, ". . dass die Erloiohterung, welche wir der gefahriosen Ausbreitung Englands durch unsere wohlwollonde Hal tung gevahren, auch wie Q11es in der Welt elnen Preis hat. In other words, Germany $\bar{y}^{\prime}$ nentrality in South Africa has its prico [Portuguese- Colonios] like overything else in the world. (Bulow to Hatzfeldt, June 8, 1898, G.P., XIV, 253, Pt. I.) 
France. You cannot afford to be on bad terms with us. 1

Evidently Chamberlain realized at the time of the actual negotiations what Grey realized much later. He said in a lotter to Balfour--during the negotiations,

The only advantage to us is the assuranos of Germany' abstention from further interferenoe in Dolagoa Bay and the Transvaal--in other words, wo pay blackmail to Germany to induce her not to interfere where she has no right of interferenoe. Nel1! it is worth while to pay blackmall sometimes.2

Here Chamberlain gave the clue to England's reasons for signing the treaty with Germany. The policy was not without success. The desertion of the Boers by the Reich and the decline of German interest in the Fashoda affair after the signing of the agreoment of 1898 is not mere coincidence. 3

Throughout the negotiations for the AngloGerman Agreoment and afterward, England continued to maintain her relationship as usual with Portugal. Apparently there was no lessening of the old friendship. Early in the negotiations (June 12) England had assured Portugal, foaring German pressure on the

1. Groy, op. o1t., I, 44.
2. Garvin, op. oft., I, 315.
3. Schmitt, op. c1t., p. 144.


loan situation, that her attitude would be the same as it was in 1873 when England stated she would not be indifferent to foreign interference in Portugal's affairs.l There was one omission in this assurance which was immaterial in 1873 but all important in 1898, namely, reference to integrity of possessions. This omission could have been purposeful. It might have been deliberately made to oause portugal some anxiety which she would be eager to dispel as soon as possible. In any case, Portugal did grant Fngland cortain concessions at the time of the Anglo-Portaguese Preaty of 1899.

Whenever Portugal became too apprehensive about the arrangement pending in 1898 betwoen Fingland and Germany, England would offer reassurances as to England's good intentions toward her old ally. However, although the reassurances were onough to show that Fngland was still interested in Portagal's friendship, they were just vague enough to inspire the proper amount of anxiety. Salisbury's and Balfour's promises to Soveral to keep Portugal informed on the outcome of the negotiations bear witness to this. ${ }^{2}$ It is perhaps

1. Saligbary to Sir H. MacDonell, June 22, 1899, B.D., I, No. 68; also Ibid., June 23, 1899, Enclosures I and 2 :

2. Supre, Ch. IV, pp. 83 and 90 . 
eren possible that Salisburg deliberately let soreral know something about the nature of the secret agreement between England and Germeny to keep up this atmosphere of anxiety. Soveral mast have been told somothing, otherwise he could scaroely have told Grey that he know all about the seoret treaty. Soveral's account of the Anglo-Portuguese agreement (contained in the Frenoh docrments) sabstantiates this.

On New Year's Day, 1899, the King of Portugal in a seoch from the throne announced that the colonial possessions of Portugal mast be maintained as a sacred horitage of the nation. I England' continued reluctance to force the agreement of 1898 and the obviously overt efforts to convey to the world the impression that Portugal and England were still the same friends as always indicate at least tacit support of Dom Cerlos' statement. Although most of the evidence proving England's desire to stand by her old friend is Indirect and besed on coinoldence, it shows a striking correlation to the fallure of the AngloGerman Agreement to be consummated and the conclusion of the Ang10-Portugnese Agroement of 1899. This

$$
\text { 1. Hammank, 으. cit., p. } 84 .
$$


correlation is so striking that it tends to support the belief that England nover fully intended to throw over her old friend.

Such an interpretation of the queer events of 1898-99 could well account for England's extreme concern for the integrity of Portugal at the same time that she was making on agreement with Germany which provided for a possible impalrment of that integrity. Evidence shows that England never wented to force the realization of the Anglo-German Agreement. 1 England, to the exasperstion of Germany, refused to hinder portugal from seouring 10 ans whioh did not Impair the letter of the Anglo-Germen Agreement by mortgaging the colonies in some way. 2

What appoars amusing now but was probably extremely provoking and pazzling to the Germans at the time was the fact that closer relations were actualiy observed with Portugal after the conclusion of the Anglo-German Agreement than before. 3 The Portaguese Ministry openly and deliberately proclaimed the close terms of this friendship and allianoe with

1. Supra, Ch. IV, pp. 96-100.

2. Fay, op. cit., p. 134 .

3. Ib1a., p. 134. 
Fngland. I fow months after the conelusion of the agreement with Germany, the British royal family, in the spring of 1899, enterteined Dom Carlos, Fing of Portugal. 2 This was but an extension of the friendship Edward, Prince of Nales, felt for Portugal throughout his Iffe. 3 Bulow blames much of the fallure of the realization of the agreement of 1898 on the intimate personal friendship between the Marquis of Soveral and the Prince of Fales."

Superimposed on the whole picture of AngloPortuguese relations from 1898 to 1899 is a pattern of confused intrigue and bargaining based on mutral fear of what each could do to the other in cooperation with another power. The approsohing Boer War was the basis of the bargaining. Fngland could use this agreement with Germeny as a lever to force Portugal to cooperate with her in the growing South African erisis. On the other hand Portagal could use the orisis in South Afrioa and an agreement that she had concluded in 1875 with the Transtaal to cause Fingland
1. Brandonbarg, op. it., p. 156.
2. Fay, op. oit., p. 134.
3. Lee, Sir Sidney, Edward VII, I, 70.
4. Bulow, op. c1t., I, 321. 
to respect the ominous potentialities of her neutrality and to value her cooperation in the approaching war. Aocording to the Mransvaal-Portuguese Treaty of 1875. Transvar was able to use the port of Lorenzo Marques as 1 ts chlef source of imports. ${ }^{1}$ Since even before the Jameson Raid, the Boers had been using the Port of Lorenzo Marques and the railway leading from it to the Tranavaal for the tranoportation of rast quantities of armaments. ${ }^{2}$ Portugal was in a position to cause the English to noutralize the intentions of the Anglo-German Agreement of 1898 . In the words of Theodore Wolff, the Portuguese were now in a position to stop the English from possibly "pulling the coat off their back at a convenient moment. 3 They could now remind the English with good effect of the old alliance treaties which bound the English "the protection of territoriel integrity." 4

On the other hand, England was in a better position to bargain than she had been a scant year previoug--before the Germans pushed themselves into

\footnotetext{
I. Salisbury to Sir H. MacDonell, September 13, 1899, B. . . . I, No. 113 .

2. Seton-Watson, op. c1t., pp. 277-278.

3. Wolff, Theodore, The Eve of 1914, p. 263.

4. Ibid., p. 263.
} 
the loan negotiations of Portagel and England. At that time England desired concessions at Lorenzo Marques. Portugal was not anxious to give them. ${ }^{1}$ In fact, the Portuguese had been very charg of conoessions until the intruding Germans appeared. This might have been one reason that Englend docided to allow Germany to Intrude. Nevertheless, England knew that Portugal still was able to cause extreme embarrassment in South Africa, if not kept friondly. Just thirteen days after the conolusion of the Anglo-portuguese agreement, while salisbury was discouraging German attompts to force a Ioan on Portugal, he reminded Portugal of the long-standing agreements between England and Portugal. 2 The purpose of this reminder was to give reason to Portugal to stop the shipment of arms to Transvaal. Soveral sald that he could not see how Portugal could consent to do this. However, he did say that Portugal would not throw over England in case of a war. In fact, she would not eren declare her neutrality in case of an outbreak of hostilities. A deolaration of

\footnotetext{
1. Memorandum by kr. Bertie on England and Portugal in Afrioa, May 1, 1898, …‥, I, No. 65 . 2. Sallabury to Sir H. MacDonell, September 13, 1899 , B..... I, No. 113 .
} 
neutrality would have made tacit cooperation with Fngland 1mpossible. Fngland could not use the strategic Portuguese colonial ports in Africa. On the serenteenth of September, MacDonell, British representative in Portugal, communicated with the Foreign office on this same matter. 1 Apparently ho had boen instructed to use pressure on the Portuguese Forelgn Minister, who temporized and suggested that England do what Soveral had boen diligently striving for, namely, arrive at a complete understanding on the matter. The Portuguese know when they had a good hand of cards and they intended to got as much as possiblo out of 1 t.

However, the British felt that they had been dealt a good hand, too. The frequent visits of Hatzfoldt to the Britioh Foreign office lod the Portaguese to believe that Germany, in conjunotion with England, was about to onforco the mysterious clauses of the Agreement of 1898. The British played this foar for all it was worth. The Britioh line of reasoning was very similar to the following account of MacDonell to the Assistant Under-eecretary.

1. SIr H. MacDonelI to Marque 8 s of Selisbury, September 17, 1899, B.D., I, No. 114 . 
They are convinoed that they have nothing to foar from the Boers, so long as they stand by us, and, having fostered an exaggerated idea of the value of their cooperation, fanoy that they can set their orn price on 1 t.

On the other hand, so long as they suspeot that we are aoting with Germany. they wiII aIways fear that-whatever may be the fortunes of war-Germany 111 eventually profit, and may prevent ne from aecuring the integrity of their territory.

As regards Loarenco Marques, they are well aware that thes cannot defend it and that thes will inevitably have to appeal to us; but they are also we11 aware that Gormany knowe this and Is scheming acoordingly . .

- - In short, the situation here 1s web of uncertainty, intrigue and confusion; the Hinisters belng moreover not of a callbre to face it.

Soveral has antil lately kept out of the way partiy from opposition to the present Ministry and partly to further his own schoms of upeetting the Anglo-Germen Areement by a direct oonvention with ne. He 1s moreover firmy convinced that all this Transtael question has been got ap by chamberIaIn, at Rhodes' and the Chartered Co.'s ingtigation; this idea is in some measure shared by the Government.

To sum up, my impression 1s that the Portuguese Government do not entirely truat as, hence their idea of a convention which would seoure them from all danger not only from the Transvaal but also from Germany. To maintain themselves in their Afrioan possessions under present circumstanoes, they required men and money. Can we provide them without the knowledge of Germany?

P17e days later Salisbury informod the British Ambassador in Ilsbon that the posalble action of

I. SII H. KacDoneII to Mr. Bertio, september I8, 1899, B.D. , I, Ho. 115 . 
Portugal in the erent of war in South Afrios had been the subject of a cabinet mooting. The Britioh Government informod Soveral that in 1ts judgment Portugal could not remain noutral in event of a war. ${ }^{1}$ The cablnet was wiling to make a defonsive allianee With Portugal against Transval in the event of a war botwoen Fngland and Transtaal. Any spocifio questions of military actions resulting from such an alliance would be deoided at the timo of necessity. Soreral's efforts to reestablish English oommitments for the integrity of Portugal were beginning to bear frutt.

Soveral soon declared his approval of such an arrangement and even volunteered to make arrangements whereby further shipments of arms to the Boers oould be stepped. 2 The only thing that remained to be done was to arrive at spocific wording of the proposed reaffirmetion of the old agroements. Salisbury preferred the wording of the "ancient treaties" to Soveral's proposal which hinged apon the delicate meaning of the word, "sovereignty"--at a time when

1. Selisbury to SIr H. Maodonell, september 23, 1899 , B.D., I, Ho. 116 .

2. Salisbury to Sir H. MacDonell, Ootober 7 , 1899, B.D., I, No. 117. Also Enclosures 1 through 5 (Soveral to Salisbury, October 7, 1899). 
Fingland was having extrome diffioulty with that word's context in reference to Pransval. 1 Salisbury insisted too that a definito clause be inserted whereby Portugal would promise not to proolaim neutrality in the imponding strife. 2 soveral agreed to Salisbury's suggestione on 0otober 7. This was fust five dags before the Krueger ultimatum of Ootober 12, which procipitated the Boer War. 3 The formal agreement was secretly signed on october 14, 1899 (two days after the Boer War broke out) and came to be oalled the "Windsor Treaty," through error by the Germans, who probably learned of it later by roundabout means. The error in the name probably results from the German belief that the treaty was conoluded when the King of Portugal (Carlos) Visited the British Royal Family at Windeor in 1899. The real Treaty of Vindsor was algned in 1904 when King Manoel signed an arbitration agreement during a visit to Windsor. The Germens might have had a mistaken understanding of the contents of this treaty. Brandenburg's erroneous account of the

\footnotetext{
1. Soveral to Salisbury, Ootober 8, 1899, B.D., I, No. 117, Fnclosure Ho. $\mathrm{g}$.

2. Ibia., Enclosure, No. 5. 3. Ploetz' Manual of Universal History, p. 619.
} 
"Windsor Treaty" is a good example of this misunderstanding. 1

According to Bulow Germany did not know of the exact meaning of this agreement until nogotiations wore re-opened in the jears 1912-1914 for the readjustment of the Anglo-German agreement of $1898 .^{2}$ He states that ho learned through a personal friend in Paris of the treaty sometime before the remainder of the German Government. His excuse for not informing the Government seems rather weak. He did not want to violate his friend's confidence. 3 Bulow gives the following aocount of his understanding of the "Windsor Treaty" :

About the turn of the century I learned, through the indiscretion of a forelgn diplomat with whom I had been on terms of friendship since my youth, that Britain, a year after her agreement with German, had concluded a secret agreement with Portugai; this was confirmod by news whioh reached mo from Parls banking circles. This agreoment, the so-called Treaty of Tindsor, expressedly confirmed existing treatios, in whioh the powerful Britain and her client of many years past, the little Portugal, guaranteed one another's possessIons, undertaking the reciprocal obligation to come in case of need to their defonse. The conclusion of the Treaty of Windsor had iargely beon promoted by the then Prince of Felos, of whom the Marquis of Soveral, the Portuguese Minister in
1. Brandenbarg, op. oit., pp. 156-1 and 176 .
2. Bulow, op. o1t., I, 321 .
3. Ibid., p. 492 . 
Iondon, was a personal and intimate friend. This Treaty of Windsor was, of course, in flagrant conflict with the spirit of the BritishGerman agreement concerning the Portuguese colonies. It was not only a guarantes for Portugal, but actually an encouragement to that country not to mortgage hor colonies. It increased the old tendency of the Portuguese to give preforenoe to Britain in all oconomio questions. To say nothing of the fact that the Treaty of Findsor further substantially increased the political dependence of the portuguese on Britain. 1

This view is hard to accept because the King of Portagal made public reference to the new Treaty in a speech in December, 1900 when the British Chennel fleet visited Portugal. This fact was pointed out by Fokarastein in his Ten Years. 2 The British Doouments substantiate him to a large extent. 3 Bokardstein's account (if true) of his actions in reference to the Anglo-Portuguese agreement is very damaging to Berlin Forelgn Office's claim of ignorance of the matter. Eckardatein asd that he asked Iord Iansdowne In the British Foreign Office what the Portuguese King's statement meant. He was told that it was a "reassertion of the Ancient Alliancen and that the

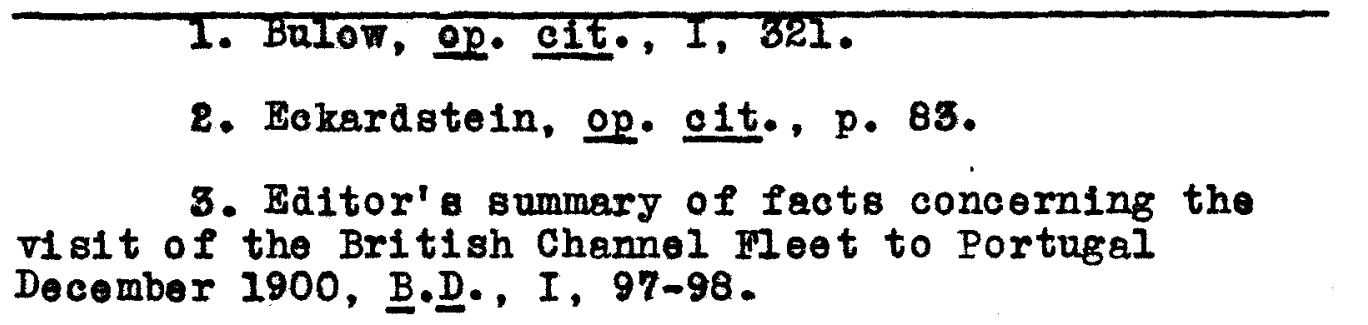


Anglo-German agreement of 1898 would be in no way affocted by it. Bokardstein's acoount says:

I telegraphed this at once to Berlin and also sent a oopy of his letter to the above effect. It is consequently inoomprehensible to mo how the Berlin Foreign Office came to believe that the expreselon "reasertion of the alliance" referred to the Anglo-Portuguese boundary agreement of 1892 that geve Great Britain a right of preemption over Delego a Bay, and why 13 years later they were so surprised when the Britioh Government again brought ap the Windsor Ireaty in the negotiations between Sir Bdward Grey and Prinoe Ilohnowsky. For they had before them the text of Iord Iansdowne'g letter in which the reaffirmation of the ancient alliance is expressly mentioned, and both the Inglish and Portuguese papers explained that the King's apeech at II sbon had referred to the focont revival of the 17th century allianoo.1

On the basis of this evidence, it is hard to explain the German Indignation after 1900 at being completely uninformed, unless Eckardstein miarepresented some facts, as Bulow intimates in his Memolrg, 2 or unless the German Government deliberately asamed an aix of ignorance about the treaty of 1899 in order to increase the feeling of animosity in Germany against England. This $1 \mathrm{~s}$ partioularly true after the German navy program began to get under way and after the Boer war broke out.
1. Eekardotoin, op. cit., p. 188.
2. Bulow, ㅇ․ c1t., p. 386. 
Balow has pointed out the intensity of German

foeling on the matter:

- . We should remind ourselves of the perfidious daplicity with which, by means of the insidious "Findeor Treaty," Britaln had gone behind our backs to render ineffectual the treaty over the Portuguese colonies just concluded with us? Should not this suggest distrust, ast it not inspire great caution? The harshness and ruthlessness with which Britain was handling all the incidents of the Boer War with regard to ourselves, the close-fisted pettiness which she displayed towards us and again partioularly towards us in all colonial negotiations, were these encouragements to cooperate Britain . . ?I

Brandenburg gives a more legaliatic reaction, which is impartial, to say the least. His account is given belor:

- a as regards the Windsor Treaty of 1899 with Portagel, orroneous title usod here it would have been more loyal and prudent not to have coneluded it, if Fingland was in earnest about on allianos. But it occurred, as we saw, after the fallure of the first overture, at a moment of sharp and almost hostile tension, and it did not run direotly counter to her engagemente with Germany, though it lent to them a very narrow and unexpected interprotation. 2

On technical grounds Germany had good reason to complain because the spirit of the Anglo-Portuguese agreement completely negated the spirit of the AngloGermen agrement. However, the English statesmen

1. Bulow, op. olt., p. 386 .

2. Brandenburg, op. c1t., p. 176 . 
would have been much more unsorupulous had they honored the German agreement and sold their staunohest friend down the river.

One loses sympathy for the German ories of perfidy when it is noted that the Roich, without consulting England, as the spirit of the dormant agreement of 2898 required, was attempting to seoure portions of Angola as well as coaling stations in the Azores, for an anti-Brit1gh Navy. Germany began to attempt to gain these concessions from Portugal before the existence of the "Windsor Treaty" was oren suspected. All she knew at the time was that the 1898 agreement with England had not beon immediately successful because of a lack of Anglish enthusiasm in pushing over a weak old friend. Nevertheless, the treaty of 1898 was still a bona pide agreement by which Germany bound herself to act in conjunotion with England in disposing of Portuguese colonies any time after 1898. No time limit had been opecified when the treaty was signed. Hence Germany was just as perfidions in spirit as England, if not more so. 1 The treaty that was signed in 1899 was in reality merely an exchange of notes reaffirming the 
old treaties. I It had this added statement, however, "The government of His Most Faithful Majesty Portugal will not proolalm neutrality in the war between Groat Britain and South Africa."L Britain had gotten the concession she wanted so bady from Portugal just two days after the Boer Far broke out. By having a benerolent non-belligerent Portuguese colonial empire at her back in Africa, the outcome of the Boer War was much more certain for England. There oan be no doubt that the so-oalled "Ireaty of Windsor" accomplished what Soveral wanted, namely, the emaseulation of the Anglo-German agreement of 1898. Portugal had played a shrewd and successful game of diplomacy, but England was twice winner; sho secured German abstinence from opposition to the English South African policy by one treaty against an old ally and used that same treaty to bludgeon support from Portugal in the South African situation-support that portugal would have otherwise hesitated to give for fear of antagonizing the dangerous susceptibilities of Germany and her darling, the I. See Appendix D for complete text of the
1899 Agreement.

2. Anglo-Portuguese Secret Declaration, October 14, 1899, B..... I, No. 118 . 
Transvaal. Truly, "Tho German diplomats had boen decieively outmaneuvered." 1 


\section{CHAPTER VI}

\section{FPIIOGUE - 1912-1914}


Following the chimerical results of the AngloGerman agreement of 1898 and the growing rivalry of the two North-Sea powers, their relations grew more and more strained. Desplte several attempts to establish a closer bond between the two powers, an atmosphere of extreme hostility developed. This development was given particular impotas after Viotoria's relgn ended, when the Edwardian Era saw the ostablishment of the fintente Cordiale betwe on France and Ingland.

The agreement of 1898 remained a more or less dormant issue between the two signers for over a decade. During this time relations between Portugal and Fngland were cordiel. During the first five days

I. Seymour, Charles, Intimate papers of Colonel House, I, 258. 
In April 1902, Edward VII visited Portugal. In a opeech before the assembled Chambers of Commeroe he gave heartfelt assurances of the British intentions to preserve the integrity of her loyel ally of old. ${ }^{1}$ On Norember 16, 1904 King Manoel of Portugal visited Windsor and signed a treaty of arbitration with England. This was the real "Treaty of Windsor" a name which many German authorities have erroneously given to the Anglo-Portuguese Agreement of 1899.2 Until about 1911 Portugal and Ingland were working to thwart German efforts to secure a harbour in one of the Portuguese colonies. 3 For the nonoe, at least, the orstwhilo collaborators for on eventual division of portuguese colonies were working at cross purposes. Reasons for this difference are explained in the growing distrust resulting from the advanced erolution of the alliance syatem and the naval rivalry. Nevertholess, there were powers at work in. Fngland and in the civil government in Germany which would have liked to have closed this ever widening breach.

1. Benson, E. F., The Ka1ger and His Engligh Relations, p. 182 .

2. .. D., VIII, 49, Editor's Noto.

3. B.D. . VIII, $49 \pm f$. 
Hence it was that the fruitless 1898 agreement was remembered. As early as June 23, 1911 , Germany began to inquire as to the possibility of division of the Portuguese colonies through the intermediary of Baron Stumm, who spoke to Sir $\mathbb{P}$. Bertie in Paris. I The inquiry was unoficial, since Stumm was not connected with the Government at this time. Metternich, the German Ambassador to Iondon, hinted to Grey somewhat later that Germany would like a division of colonies to take place as soon as poseible.2 By 1912 Germany had specifically suggested that negotiations on the Portuguese question be revired. 3 The urgent need for amending relatione was obvious.

Ciroumatances seemed more opportune than they had for some time. The ancient Portuguese Monarohy had been overthrown on october 5, 1910 by the republicans. These republicans, with a somewhat narrow outlook wished to find some soapegoet on which to blame Portugal's trouble. They attributed exclusively and

1. Sir Hertio to Sir Edard Groy, Pario, December 21, 1911, B.D.. X, Pt. II, No. 265 .

2. Sir Edward Grey to Sir E. Goschen, December 29, 1911, B.D., X, Pt. II, No. 266 . p. 387 .

3. Stood, H. W., Through Thirty Years 1892-1982, 
conveniently the evils of the Monarchy, brought on largely by carelessness and indifference and the ir own legislative bickering, to the House of Braganza, the Jesults and the British Alliance. 1 The German Minister at Lisbon in 1913, in summarizing the course of the revived negotiations up to January 20, 1913, described the situation as follows:

In Germany the logioal effect for some jeare after 1899 was neceaserily that the Portuguese buginess was considered to have been a failure and to be over and done with. Not until the efforts of Imperial polioy produced a desire for normal relations on both sides of the North Sea was the Portuguese colonial problem again brought to the fore, less perhaps at first because of the intrinsic value of the Portuguese colonies than in order to find an advantageous basis for negotiation. between two countries. . The fall of the Monarchy in Portugal made it considerably easier for the British Government and public opinion to further draw away from their ally, the Republic, with its apparently chronicaliy anarchical conditions, and after securing for ingland the most valuable portions, to bo content to make not inconsiderablo sacrifices in Germany's favour. . . As then 1898 Ingland and Germany are agreeing on a policy of partition, and Portugal again equaliy appears to have reached the end of financial resources.

Rosen's summery covers the resumption of the Portuguese question very comprehensively and rather accurately; however, several points are omitted which

1. BeII, Aubrey F. G., "Chaos In Portugal," from These Eventual Years, p. 176 .

2. F. Rosen, Minister at Lisbon to Chancellor Bethmann Hollweg, January 20, 1913, Dugdale, E.T.S. ㅇp. ㅅt., IV, 22I-222. 
give the English standpoint a somowhat different a.spect.

It is hard to explain the British reason: for permitting the long moribund question to be exhumed; however, it is a well-ostablished fact that Sir Edward Grey was extremely anxious to offer the olive branch to Germany in order to ond the long period of dissension.? But what the German Government falled to understand was that while sir Edward Grey felt bound to honor engagements into which Balfour and Chamberlain had unwisely entered, he was equally determined not to be disloyal toward Portagal. 2

With Grey trying to satisfy these two incompatible goals, the negotiations were doomed to have a stormy course because the Germans regarded as insincerity what Steed oalls "two concurrent though erentually incompatible honesties." ${ }^{3}$ Grey explains his dilemma in this manner:

1. Robertson, Malcolm, Introdaction to VOI. IV, German Diplomatic Documents, January 20, I931, DagdaI0, E.1.S., op. elt., IV, xiv.

2. Steod, op. cit., p. 338 .

3. Ibid., p. 338 . 
As to the future it is olear from what Metternich has already said to me that the Germans would like the division of the Portuguese Colonies to take place as soon as possible. So should I. These Colonies are worse than derellot so long as Portugal has them - . the Union of South Africa will never rest till it has Delagoa Bay: on every ground material and moral and even Portuguese it would be better that Portugal should sell her Colonies. But hor can we of all people put pressure on Portagal to sell: we who are bound by an Alliance to protect and preserve her Colonies for Portugal--an Alliance renewed secretly for value recelved during the Boer war? And Portugal won't part with her Colonies--any regime in Portugal that did so would be overtumed by a revolution-for when nations have gone down hill till they are at their last gasp their pride remeins undiminishod, if indeod it is not increased. It clings to them as Tacitus says the lore of dissimulation clung to Tiberius at his last gasp.l

Trevelyan, Grey's apologist, states that he attempted to olarify rather than to complicate the tangle.2 At any rate England did not do as Tirpitz blatantly accused--deliberately offer Germany territory that was not Fnglioh in order to placate Germany. 3 Iora Haldane, speoiel representative to Berlin in 1912, explained the situation as merely being an undertaking to agree about possible zones. which each nation might purchase or exploit should they be placed on the

1. Sir Edward Grey to Sir E. Goschen, December 29, 1911, B.D., X, Pt. II, No. 266 .

2. Trevelyan, G. M., Grey of Fallodon, pp.269 $\mathrm{ff}$.

3. Asquith, H. H., Genesis of the War, p. 97. 
market. ${ }^{2}$ This explanation, of course, was only the literal interpretation. Potentieliy the treaty was much more dangerous for Portugal. However, Germany was the initiator of the new negotiations, not England.

While the conversations for a renewal of the 1898 agreement began as early as 1911 under the gaidance of the German Ambassador Mottermich, it was not unt1l 1912 that the negotiations began to take a more definite shape under the guidance of Prince Iichnowsky, the now German Ambassador, who took over in November 1912. He began onergetically, almost at the moment of his arrival, to attempt to accomplish something defintte on the Portaguese question. Within three days after he presented his credentials to London he was able to induce Grey to draw up a draft agreoment revising that of $1898 .^{2}$

Iichnowsky was very well liked in London and apparentiy enfoyed the confidence and cooperation of the government there to a remarkable degree. Throughout his account of the drawn out (two years) dealings on the question he showed a generous appreciation of 1. Haldano
the War, p. 145. 2. Nicholson, op. ㅇt., p. 285 . 
England's viewpoint, Ilchnowsky was interested in the concomitant possibilities of the treaty as much as, if not more than, the possibility of immediate material gain it offered Germany. The ner German Ambassador completely understood Grey's Insistence on publishing both the Anglo-German agreement on Portuguese colonies as it would be revised and the Anglo-Portuguese $D_{\theta}$ claration of 1899. Greg had arrived at such a decision long before Iichnowsky took over the negotiations--in January 1912 to be

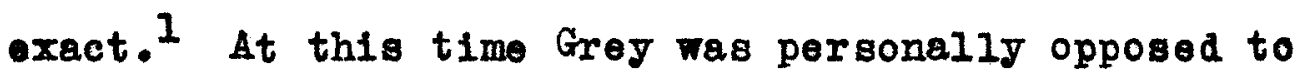
secret treaties which he regarded as embarrassing and inconvenient. 2 Despite the rather oallous negotiations that occurred under Grey's supervision as to what country might get what section of Portugal's domain, it seems that Grey did not want to regard the possibility of a restatement of the 1898 agreement parely as a means of enlarging the domain of the Empire. It would seem rather that Lord Haldane was right. Grey merely wanted to use the renewed negotiation as a means of destroying the rancor in Germany

\footnotetext{
1. Grey' Minute to S1r Eyro Crowe's Memorandun on Timor and the Anglo-Germen Secret Conventions of 1898, January 26, 1912, B.D., X, Pt. II, No. 270. No. 364 .

2. Grey to Sir Francis Bertie, B.D., X, Pt. II,
} 
and the uncertainty in Portugal resulting from the diplomacy of 1898-1899. Guedes states that Grey promised the Portuguese President Teixeire Gomes categorioally that he would not sign the modification without the expressed condition that it would be immediately published as would also be the embarrassing secret treaties of 1898 and 1899.1 Grey's probable reasons for publishing all of these agreements simultaneously was to show to the world that Fngland was not as perfidious as the mystery about the 1898-99 situation made England appear. He, of course, had to publish the treatios if he wanted to show their hypothetioal nature and if he wanted to allay the suspicions of Prance that England was about to debilitate the otrength of the Entente Cordiale. 2 Here again Grey was striving to overcome another dilemma--establish better relations with Germany while keeping Germany's enem, France, friendiy to England. Iichnowsky's appreciation of these delioate intricacies is best shown by a note with which he prefaced his discussion of the Anglo-German Colonial Convention in his Auf dem Fege zum Abgrund--Heading

$$
\begin{aligned}
& \text { 1. Guedes, op. OIt., p. } 336 \text {. } \\
& \text { 2. …․, X, Pt. II, } 559 \mathrm{ff} \text {. }
\end{aligned}
$$


Por the Abres:

From the outset the British Government, for reasons of home and forelgn policy, laid it down as a gine qua non for the conclusion of a now treaty that both the new treaty and all the old ones should be published. Sir E. Grey also considered it of great importance that 'this treaty should demonstrate the unanimity between the two Governments and show the world that it was possible to reach agreement in suoh fields.' Deapito this plain statement it was not till shortly before the outbreak of the war that the German Foreign office could be induced to permit the publication and ratification of the new treaty, long after it was complote! One pretext after another was sought in order to find some way of rendering the treaty abortive. - The whole attitude of the British Minister, at any rate, showed his sincere desire for a rapproohement with us, I

Even though the conditions requisite to a signing of an agreement seemed unsurmountable, the German Ambassador was able to get a revised agreement down on paper. All that remained was to iron out spooial changes that oach side wanted to insert into the old arrangement. To accomplish this, tedious dickering continued from December 1912 to October RO, 1913, when a final draft was initiallod (not offiolally signed) by Grey and Liohnowsky.2 Most of the agreement was very aimflar to that of 1898. Several significant p. 270 .

$$
\text { 1. Prince Iichnowsky, Heading for the Abyse, }
$$

2. B.D., X, Pt. II, pp. 428-540. Also G.P. XXXVII, 13-86.' See Appendix $\mathrm{E}$ for text and Appeñdix $G$ for illustration of territorial disposition. 
alterations were made, however. These alterations

were explained by the German Minister at Iisbon' comments on the agreement to his Chancellor. He said:

In the natare of the case comparison of the two Conventions follows on two lines, partition of spheres of interest and the possibility of making the convention effective. The loss of the Portuguese half of the island of Timor--the gaining of which by us was always more than problematioal-and of the strip on the left bank of the Zambezi is, in my opinion, more than paid for by our aoquiring the contral part of Angola and by the British desinteressement regarding st. Thomas and Prinoipe, which two 1slands form the most valuable part of all Portugal's colonial Empire. What we give up in Africa--the Zambezi territory which is ontirely controlled commercially by Finglishmen, and a comparatively small portion of oastorm Angola, is hardly worth consideration as against the fact that now our sphere of influence in Angola will, With German Southwest Afrioa, form a compact colonial territory with a coast covering 20 degrees Iongitude, whose good harbours and fertile highlands, suitabie for settlement, promise highly prosperous future developments.

As regards partition of the country the advantages of the new Convention seem to me even greater, when I consider its possibilities. The Convention of 1898 was founded on the assumption that portugel wa faced with an inevitable financial collapse and would be glad to pledge her colonial customs for a loan granted by Germany and England. This assumption proved false. Since then Portugal has raised no loans of any size. Financially she has--although with dificulty-kept her head above water, and lately sho appears to have wiped off her defiolt and balanoed her Budget. Your Exeellency has realised this in good time and has thought well to introduce into the new Convention certain clauses taking account of our aspiration without reference to Portugal's need of a loan, so that we neod not foar again 
that what we have won by treaty will be lost to us in practico.1

What Rosen significantly adumbrated in the closing lines of his dispatoh was the most radioal departure in the new agreement from that of 1898. The eighth clauge in the Draft oonvention of 1913 made provision for joint interference by the German Reich and British Empire in the Portuguese Impiro in event of any disturbance or irregularity in the Portuguese colonies which would endanger the liver, property, or vital interests of German and British citizens. If the treaty were activated with such a clause, the realization of its material aims would be accomplished much more easily by the designing powers.

Grey probably realized the terrifio import of this clause. Hence his insistence on the publication of the treaties so as to leave no element of doubt anywhere. Everyone concerned, including portugal, would realize the enormous potentialitios of the treaty and would consequently do everything to avold creating an excuse for its consummation. This

$$
\text { 1. F. Rosen, at Iisbon, to the Chanoelior, }
$$
Bethmann-Hollweg, November 9 th, 1913, Dugdale, E.T.S., op. cit., IV, 228-229. 
would act as a brake on the Portuguese ineffiolency and possibly lead to reformation of the very unstable political situation in Portugal that the Germans were banking on for the realization of their appiration in the draft agreoment. This was specifically expressed by Rosen in his report of January 9, 1913. Rosen, Solf (Germen Colonial Secretary), and Ilohnowsky were not opposed to immodiate publication. However, the Germen government hesitated in opite of the fact that Grey stated that he would not offioially sign the new agreement unless it were made public. Iichnowsk said that his government refused to accede to Grey's requirement because there were people in the government who were personally jealous of his successful beginnings on a new Anglo-German understanding. I Although this might hare some bearing on the case it is likely that the German government had a more fundamental reason than this. Probably Germany did not want to make Portugal wary and then, too, if the treaties were openly proclaimed, Frenoh suspioions of England would be allayed. France would see that Angland had not concluded a revolutionary agreement with Germany but merely a clarification 
of an agreement that originated before the establighment of the mtente cordiale. German apologists such as Count Montgelas maintain that the Germans were more sincere about the ultimate possibilities of a broad understanding that this revival possessed than was Ingland. 1 However, the main ourrent of German polioy at this time disprores Montgelas' contention. Germany might have reopened the treaty in the weak hope of using it as a means of purchasing British neutrality.2 Grey's insistence on publication of the documents would destroy this value of the negotiations beceuse the exhibition of the contents of the treaties would show that England had no desire to arrire at an understanding with Germany at the expense of the English allies. France would know that she was not being deserted. Publication would show that the foundation of the Anglo-German arrangement was laid years before the Entente Cordiale was consummated. Such an interpretation of the actions of Berlin in these negotiations gains credence when it is observed that Bethmann-Hollweg suddenly agreod to publication

\footnotetext{
under Grer, p. 52 .

1. Montgelas, Max, Brit16h Foreign Policy

2. Dugdale, E.T.S., ㅇ․ c1t., IV, 217 (Editor's Note).
} 
of the documents in question on July 2, 1914.1 Germany was willing to accode to the British conditions of publication only at the last moment before the war broke out. They did this in the vain hope that such a concession to British desires might parchase British neutrality in the forthooming confliot. The Arohduke Franz Ferdinand and his wifo had been assassinated June 28.

The epilogue to 1898 merely substantiates what the tangle of 1898-99 began to vaguely indicate. The duel for Empire might allow for understanding on small points, but fundamentel differences were too large to make possible a unity of action. Nicholson correctly sums up the situation by saying "Anglo-German friendship remained, however, superficial. Benoath the sugar-ooating of these amenities the old fear and rivalry had lost none of its bitterness." 2

1. Ilchnowsky to the Chanoellor, July 14, 1914, Dugdale, E.T.S., op. o1t., IV, 233.

2. Nicholson, op. cit., p. 286. 


\section{CHAPTER VII}

CONCLUSIONS-WHO PAID THE PIPER 


\section{CHAPTER VII}

\section{CONCLUSIONS--WHO PAID THE PIPER}

If judged in the cold light of objectivity and theory, Iord Carnook (Arthur Nicholson) was correct when he called the convention regarding the Portuguese colonies the most cynical business that he had ever run acrose in his whole experience of diplomacy. A friend, whose loyalty had been proven for over five hundred years, was the unwilling subject of negotiation between the world powers whose rivalry was very outspoken. Portugal was given no voice in the negotiations which took adrantage of her internal weakness to use her as a means of placating, temporarily, two ravenous powers bent upon ultimately destroying one or the other. The apparently useless friend was to be the soapegoat. This interpretation is the most evident one and superficially at least-if only the theoretical aspects are considered--is quite plausible and true. However, the fact still remains that the Portuguese Empire is intact to this day with the possible exception of Timor which is jeopardized by a power not directly involved in the 1898-1914 negotiations. During World Wiar I PortugeI and Fngland remained allies as of old and fought side 
by olde against Germany, with whom the letter of the Anglo-German colonial treaties had provided for a possible partition of the portugueso colonies. The old Portuguese alliance was stronger than the possibilities contained in the Anglo-German colonial declarations.

Evidently, then, in spite of the theoretical provisions of the Anglo-German colonial agreements, Portugal had not been deserted by her time-proven ally. There are several possible explanations that made the ominous situation turn out so favorably for Portugal. A first and obvious explanation might be that England nover intended to desert her old friend and remained true to her alliance commitments of old. A second explanation might be that Portugal's Iriendship still had a material value to Fngland despite the chaotic condition of Portugal's govermment. A third explanation might be found in coinoidental events, which by chance made possible the continuanee of the old relationship.

Salisbury's unvarying reluctance to conolude the agreement with Germany and his shifting the responsibility of it to his nephew might be used as proof of the first explanation. Sel isbury never relighed the 
Idea of the treaty. His promides to keep Soveral informed and his probable informing soveral of the contents of the treaty of 1898 would tend to substantiate a belief that the English Cabinet, or at least a most influential part of it, never really intended to sell Portugal "down the river."l Possibly Salisbury let the Chamberlain element of his Cabinet play with the idea of an alliance with Germany based on a colonial agreement. By doing this he could fuse the odd elements in his government. There were several factions in the Cabinet. Indirect evidence to support this is abundant. Salisbury was at odds with his own nephew. Sir Franois Bertie's retrospective interpretation of Salisbury's declining influence in his own Cabinet substantiates this.? Guedes declares that there were differenoes on the colonial questions betweon Salisbury and Chamberlain. 3 This difference between the Colonial secretary and the Prime Minister approached a rivalry.4 Salisbury pp. $106-10 \frac{\text { sup }}{10}$

2. Sir F. Bertio to Sir Edward Grey, January 12, 1912, B.D., X, Pt. II, No. 268. Also Supra, Ch. IV, p.83.

3. Guedes, op. ait., p. 330.

4. Hoyningen, Heinrich Freiherrn von, Undersuchungen zur Geschichte des deutsch-englischen BundnisprobI0ms, 1898-1901, p. 109. 
might have used this situation in his Cabinet to bait Germany into believing that there was a possibility of foroing Fingland to reach a colonial agreement by playing one element of the Cabinet against the other. All the time he may never have intended to use the treaty unless compelled to, because of respect of the force of public opinion, which never would have fully condoned the desertion of Portugal. I The fact that the Portuguese Government, never extremely anxious about the negotiations, remained on the best of terms with England throughout is possibly an indication of some kind of assuranco that England would never desert her. This faot is ofther an indication of assurance or an indication that the seoret elemente of the treaty were really secret. However, the negating effect of the subsequent English and Portuguese Treaty of 1899 seems to disprove the latter conoept. That is, the Portuguese mast have known of the secret agreoment between England and Germany, otherwise they would not have entered into the agreement of 1899 with Fngland. Soveral's profession of complete knowledge of the negotiations of 1898 also refutes this view.

$$
\text { 1. Iichnowsky, op. c1t., p. 312. }
$$


The second explanation of the ineffectiveness of the German-English Colonial Agreement has even more substantiation. Portugal's friendship etill had a definite value in 1898. At this time Germany thought she had England in an embarrassing position and sought to gain what sho could in return for German neutrality in the Boer situation. Consequently, Fngland was forced, more or less, to sign the agreement. However, instead of getting what she had expected because of this treaty, Germany was actually thwarted. Now Germany could not act unless she acted in conjunction with her co-signer, England. If Fngland refused to act, Germany had to wait. The German government could not complain to the world about the unfairness of such purposeful dalliance because it would immediately reveal its own secret involvement in a deapicable agreement which the world could decry and which other powers probably would demand to be settled by an international conference of some sort. Such a conference would, of course, destroy any advantages England and Germany would jointly onjoy as a result of the secret agreoment. However, it would not destroy rights of pre-emption to certain portions of the portuguese Colonial Empire 
which England had held by previous bona fide agreements between the British Empire and Portugal. Germany unwitingly forcod herself by poor judgment in treaty making--while forcing England--to depend on the doubtful possibility of England's agreeing to overthrow Portugal. This was a possibility which Fngland never could afford to make actual as long as there was a Boer danger. Portuguese benevolence in the forthcoming war was too valuable. The Declaration of 1899 between Portugal and England amply proves this point. The suspected assurances Salisbury gave Soveral would also tend to prove this as would Portugal's continued friendship and relativo calm amid the overtiy despicable negotiations of England with Germany.

The third explanation of the failure of realization of the declared results of the colonial negotiations depends on circumstance. If the Boer danger had not been present in 1898 and if the World War had not come at the very moment a second agreement was about to be signed in 1914, and if more adroit diplomats had framed the German course of action, Portugal might have been sacrificed as the colonial agreements of 1898-1914 seem to indicate. 
Perhaps a simpler interpretation than any of the three given would be a statement saying that ovents show that the Anglo-German colonial agreements never realized their avowed purpose because they were at cross purposes with the course of the greater current of the history of the time--duel for empire.

Specific conclusions concerning the negotiations can be made however. They are as follows:

1. Portugal unconsciously sot up the situation for the Anglo-German colonial agreements by asking for a loan based on colonial revenues at a time when her financial oredit was of doubtful value.

2. Germany in oach instance instigated the negotiations between the Relch and Ingland for disposal of Portugal's colonies. England entered the agreements only after German pressure pointed the way.

3. Portugal gave no approval to the AngloGerman agreemente which ignored her soverelgn right to have a volce in the disposal of her own property.

4. Portagel did not lose her Empire even though England and Germany had an agreement providing for an eventual dirision.

5. Germany was definitely out-maneuvered.

6. Portugal recelved more material benefit 
from her secret treaty than did Germany. The Portuguese colonies were more valuable to England during the Boer War as Portuguese colonies than as German possessions.

7. The Boers lost their best hope for aid because of the Anglo-German and Anglo-Portuguese agreements.

8. Chamberlain was partially to blame that h1s desired alliance with Germany was never realized because it was at cross purposes with his colonial ambitions.

9. There was not complete unanimity in the British government on the desirability of conoluding the Anglo-German-Portuguese deal.

10. Secret treaties become increasingly more embarrassing in proportion to the time they have been kept secret.

11. Fingland and Germany arrived at an agreement on the Portugrese question because of the desires of some members of the Governments of the two Empires. However, the general policy and desting of the nation, and their government never sincerely or enthusiastically pursued such a desire. Spectfic agreoments on isolated points of difference between rival powers 
are valueless unless a broad sincere general understanding has been reached and supported by the entire government of both contending powers.

12. Both England and Germany were using the colonial agreement for ulterior reasons. Fngland's ulterior reasons for signing the agreements with Germany have been fully explained. Germany had other reasons besides colonial gain which caused her to sign. Bulow (in retrospective discussion) says that the treaty was merely a trial balloon to determine if England was still perfidious Albion: "In this treaty of 1898 I was concerned not only for the actual subject of negotiations, the partuguese possessions in Africa, but also for the opportunity of establishing how far we can rely on British bone fides." The military elements of the German government wented the treatios to act as a camouflage of friendliness for their increased rivalry for naval supremacy.2 It is believed that the revival of the negotiations prior to the world war was made with the hope of getting Fngland to remain neutral if a world

1. Bulow, op. c1t., I, 320.
2. Dugdale, E.T.S., op. cit., IV, 217.


war were to ocour. I According to Ilchnowsky, Fngland was anxious to turn German energies into channels less dangerous to England. The English had some hope of sublimating the energy expended in Germany on an increased navy into a less harmfal (to England) policy of colonial expansion.2 Colonel House was probably right then when he said that each power was afraid of the other but unwiling to make the concessions that would make for a straightforward understanding.

13. The agreement of 1913-1914 was an outgrowth of 1898 .

14. The agreement of 1913-1914 was more dangerous to. the integrity of portugal.

15. Germeny and England had different concepts of the treatios. England believed that the treatios would not become effective until the sovereignty of portugal was impaired. Germany believed this too, but she wanted to contribute to the impairment of the sovereignty so that the treaties could become active. 16. The background of the Anglo-German-Portuguese coloniel problem indicated that a departure from

1. Dugdale, E.T.S., op. oit., IV, XV.

2. Iichnowsky, op. c1t., p. 226. 
splendid isolation was imminent. However, Salisbury, one of the last champions of this theory of policy, whose archaic nature even he reluctantly realized, made perhaps the last brilliant play of this polioy. While Ingland stood alone he shrewdy pleyed other powers against one another to extricate England from a difficult situation. He played the noeds, ambition, and fears of Germany, Transvaal, Portugal and France against one another. "Salisbury without exaggeration was one of the greatest British foreign ministers of the century. After Bismarck's fall, his primacy in world politics was unchallenged."I

Madaling through had won another briliant victory. Portugal did not pay the piper as the theory of the treaty would have one believe. The second-rate statesmanshlp of Wilhelminian Germany caused the Reich to pay the piper.

1. Ward and Gooch, op. cit., III, 262. 
BIBLIOGRAPHY 


\section{BIBIIOGRAPHY}

I. PRIMARY SOURCES

\section{A. Doc Unarirs}

Britigh Documents on the Origing of the Fer 1898-1914, Gooch, G.P. and Tomperloy, Harold, ditork, Printed by His Majesty's Stationery Offioe, London, 19271938 .

Britigh Fore1gn and State Papers, Volume 97.

British Parliementary Aocounta and Papers (1899), CIX TC9088).

Die Grosse Pol1t1k der Furopaisohen Kabinotte 1871-1914, samming dor Diplometiochen akten des luowertigen Amtes, Im Auftrage des Auswartigen imtes, heransgeben ron Johannes Iopsius, Albrecht Mondelsbohn Bartholdy, Trodrich Thimmo. Doutsoho Vorlagsgesellsohaft fur Politik and Goschiohto, Berlin, I984.

German Diplomatic Documonts 1871-1914. Selocted doonments transiated Irom Die Grosse Politik der Europaisohen Kabinette by Drgdalo, H. T. 5., Harper and Brothers, Publishors, New York, 1930.

Mnistere Des Affalres Ptrangeres Commisgion De Publication Da Doouriont Rolatits aux orlgina de La

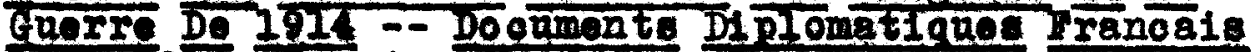
1811-I9I, Imprimerio Nationalo, Paris.

B. MBMOIRS

Asquith, Henry Herbert, Genesis of the Her. Nen York: George H. Doran Company, 1923.

Bulow, Prince ron, Momolrs. Boston: Iittle, Brown and

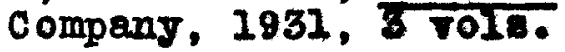

Eokardstein, Baron von, Ien Years at the Court of saint

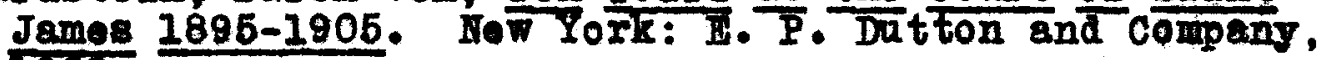
1928. 
Hammann, Otto, World Policy of Germany 1890-1912 (A Huttman 162 translation). London, G. Ll1en and Unwin 1td., 1927.

Grej, Bdward, Trenty-F1ve Yearg 1892-1916. Hew York:

Frederiok A. stoxes Company, 1986.

Haldane, Viscount RI chard Bardon, Before the Ear. Now York: Funk and Wegna11s Company, I9ZO.

Prince Ilohnowaly, Heading for the Abres Reminiecences (Professor sefton Dolmor's Tranglation). LOV YorE: Pojson and Clarke, Itd., 1928.

Steed, H. W., Through Thirty Years. 1892-1982. Garden City, How York: Doubloday, Page and Company, 1925.

Tirpits, Alfred Peter Irederiok, Yy Memolrs. Iondon: Hurst and BIaket, Itd., 1918.

II. SECOIDARY SOURCES

\section{A. BIOGRAPHIRS}

Cec11. Algernon, Britigh Pare1ge Secretaries 1807-1916. How York: G. F. Putnañs sons, I9\&.

Dugdale, Blanohe, B. C. (niece to Balfour), Arthur James Balfour. London: Hutchinson and Company, 1966.

Garvin, J. I.. Ilfe of Joeeph Chamberlain. Iondon: Hacmilan añd Compañ. LImited, IStr.

Ioe, S1r Sidnoy, King Eaward VII, A Blographr, New York: Macmilian Company, 1925, 2 V018.

Nicholson, Harold (son of Sir Arthar Nicholwon). Portrait of a Diplomatist, Being tho Iifo of sir Irthur Hicholson, First ford of Carnock, and a Study of the Origins of the Great Har. Boston: Houghton Mifin Company, 1980.

Trevelyan, George Macanlay, Grex of Falladon, the 11 fo and letters of Sir Edward Grey afterwards V1scount Gres of Falladon. Bogton: Hought on Mifflin Company, 1987. 
B. BO0K8

Benson, F. F., The Kaiser and His Fnglish Relatione.

Hew York: Iongmans, Gre日n and company, 1936.

B1xler, Raymond, Anclo-German Importaliem in Sonth Afriea. Baitimore: Verwick and York, Inc., I0se.

Brandenburd, Erich, Prom Biamarak to the World Var. Iondon: Oxford Prese, I02\%.

Bryoe, James, et. al., Briton and Boer. Ifew York:

Harper and Brother8, Pabl18hers, 1900.

Carroll, R. M., Germany and the Great Powers 1866-1914.

Now York: Prentice-HaII, Tnc., 1988.

Fay, Sidney B., Origing of the World War, Second Edition. How York: Macmillan Company. 1938.

Groen, John Richard, History of the Engligh Peoplo, Vol. III. New York: WIIIam T. AIIfion, 1889.

Grodes, Armando Marques, Allanea Ingleas Notas De

Historica Diplomatica. editorial tnololopodia. I. Da I18bos ViciexuriI.

Hale, Oron James, Publioitr and Diplomacy, with Special Referenoe to England and German 1890-1914. How York: D. Appleton-Century Company, 1940, 3 rols.

Hoyningen, Heinrich Freiherrn ron, Onderguchungen gux Gesohiohte des doutsch-ong 11 sohen Bundni sproblems 1898-1901. Breslak: M and H Marcus, 1934.

Ianger, William Ieonard, Diplomacr of Imperialiam 18901902. New York: A. A. KnopI, 1935,2 Tols.

Larson, I. M., A Short History of England. How York: Henry Holt and Company, 1924.

Iotell, R. I., The Struggle for South Afriog, 1875-1899. Now York: Macmilian company, 1934.

Macaulay, Thoma Babington, The History of Angland from the Accesst on of James II. Chicago: Doñhue Henneberry and Company. (no dato). 
Montgelas, Count Max, British Forelgn Polioy under Grex. New York: Alfred A. KnopI, 1928.

Newt on, A. P., A Hundred Years of the British Bmpire. Now York: Macmilian Company, 1940.

Ploetz' Manual of Universal History, Harry Hlmor Barnes' revision of the Willam Tillinghast edition. Boston: Hought on Mifflin Company, 1933.

Schmitt, Bernadotte, England and Germanr 1740-1914. Princeton: University Pre 88, 1918.

Seton-Watson, R. W., Britain in Earope, 1789-1914. New York: Macmilian Company, 193\%.

Seymour, Charles, Intimate Papers of Colonel House. Boston: Hought on Miffin Company, 1926.

Temperley, Harold and Penson, Lillian, Foundations of British Foreign Polior. Cambridge, England: Unitrersity Press, 1938.

Ward, A. W. and Gooch, G. P., Cambridge History of British Forelen Polior. Now York: Macmilan Company, I98E.

Wolff, Theodore (editor of Der Berliner Tageblatt), The Eve of 1914 (translated by E. W. Dike). Wow York: IIfred L. Knopf, 1936.

\section{ARTICLES}

Bell, Aubrey, F. G., "Chaos in Portugal," These Eventful Years. New York: Enc yclopedia Britannica Company, Inc., 1924.

Jones, Guernsey, Beginnings of the Oldest European Ailiance: Ingland and Portugal, American Historicel Association Report for 1916, Vol. I, 40\%-419. 


\section{APEENDIXHS}


Convention signed on the 30th instant between Great Britain and Germany, respectIng the position of the two Powers in connootion with a possible loan to Portagal on the security of the oustoms revenues of the Portuguese Provinoes of Mozambique and Angola, and the portuguese portion of the Island of Timor. 1

Enclosure in 110.90

\section{Conrention}

In viow of the posgibility that Portugal may require financial assistance from some foreign Power or Powers, and in order to obviate the international complications which such a condition of things may produce, and to preserve her integrity and independenee, the Undersigned, duly authorised by their respective Sovereigns, have agreed as follows:

I. Whenever either the British or the German Government is of opinion that it is expedient to accede to a request for an adranoe of money to Portingel on the security of the customs revenues or other revenues of Mozambique, Angola, and the Portugnese part of the Island of Timor, it shall communicate the lact to the other Government, and the other Government shall have the right to adrance a portion of the total sum required.

In the erent of the other Gorernment signifying its intention to exercise this right, the two Governments shall consult as to the terms of the two loans, and these loans shall be issued on the security of the Cus toms revenues of Mozambique, Angola, and Portuguese Timor as near as possible simultaneously. The loans shall bear as near as possible the same proportion to each other as the amounts of the custom revenues respectively assigned as their socurity.

The loans shall be issued on terma as favourable to Portugal as the condition of the money market and

\footnotetext{
1. Ir. Balfour to SIr F. Lagoelles, Augugt bI, 1898, B.D., I, pp. 71-72, Enclosure No. 90 .
} 
the security of the loans permit, and shall in other respects be subject as near as possible to similar conditions.

II. Of the Customs revenues, referred to in Articie I, those of the Provinee of Mosambique south of the zambezi, and of the part of that provinoe $1 \mathrm{ying}$ on the left bank of the Zamberl abore its confluence with the Shire, and those of the portions of the Provinoe of Angola, as hereinafter described, shall be 88 signed to the British loan. The Customs revenues of the remaining parts of the Prorinces of Mozambique and Angola and the Customs revenues of Portuguese Timor shall be assigned to the German loan.

The portion of the Province of Angola, of which the Customs revenues shall be asigned to the British loan, is comprised within the following limits: the northern frontier shall run from the coast along the 8th paraliel of south latitude to the 16th dogree of longitude east of Greenwich, thence it shall descend that degree to the 9 th parallel of latitude, and shall follow thet parallel eastwards as far as the Irontier of the Congo Pree State. The southern frontier shall start ir a point on the coast 5 English miles north of Bgito, and shall run thenoe due east to the eastern frontier of the provinee of Angola. The western frontier shall be the sea; the eastern frontier shall be the eastern limit of the Province of Angola.

III. Any Delegate sent by Great Britain or Germany to take note of the collection of the revenues whioh are the security for thetr respective loans shall have only rights of inspection, but no rights of administration, interferenco, or control, so long as there is no default in the peyment of interest or sinking fund.

IV. In case of default in the payment of the interest or oinking fund of eithor loan, the administration of the various oustom-houses in the two provinces and in Portuguese Timor shall be handed over by Portugal; those assigned for the German loan to Germany, those assigned for tho British loan to Great Britain.

V. It is woll understood that all rights, whether British or German, acquired in the provinces affeoted before the date of this Convention, shall be fally 
safeguardod, provided they are of a purely private character, and convey neither politicel rights nor territorial or administrative jurisdiction.

It is also understo od that no influence $\mathbf{N i l l}$ be used in the future, either by the Britioh or the German Governments, to obtain Iresh Conoessions, except in these portions of the provinces of which the custome revenues are assigned to their respective 10ans.

VI. The present Convention shall be ratified, and the ratifications thereof hall be exchanged as soon as possible. The convention shall come into force immodiately after the exchange of ratifications.

In witness whereof the Undersigned, duly authorised, have signed the samo, and have affixed thereto their seals.

Done in duplicate, at Iondon, the 30th day of Augue $t, 1898$.

$$
\begin{aligned}
& \text { (L.S.) ARTHUR JAMES BATFOUR } \\
& \text { (I.S.) P. HATZFELDT }
\end{aligned}
$$




\section{APPENDIX B}

Secret Convention between Great Britain
and Germany

Enclosure in No. 91

Socret Convention

Whoross, notwithstanding the provisions of the preceding Convention of this day's date, it may unfortunately not be found possible to maintain the integrity of the African possessions of Portugal south of the Equator, as well as of those in Timor, the Undersignod, duly anthorised by their respective sovereigns, have further agreed as follows:

I. Great Britain and Germany agree jointly to oppose the intervention of any third Power in the Provinoes of llozambique, Angola, and in Portuguese Timor, either by way of loan to Portugal on the seourity of the revemues of those protinces, or by way of aoquisition of torritory, by grant, oeseion, purchase, lease, or otherwise.

II. It is anderstood that, from the conclusion of the conventions of this day's date, Great Britain will abstain from advancing any claim of whatsoever kind to the possession, occupation, control, or exercise of political influence in or over those portions of the Portuguese provinees in which the Customs revenues have been assigned to Germany, and that Germany will in 11ke manner abstain from advancing any olaim of whatsoever kind to the possession, occupation, control, or oxercise of political influence, in or over those portions of those Portuguese provinces in which Castoms revenues have been assigned to Great Britain.

III. In case Portugal renounces her sovereigh rights over Mozambique, Angola, and Portuguese Timor, or 10808 these territories in any other manner, it is understood that the subjects of, and natires of the Protectorates of, one Contraoting Party, together with their goods and ships, and al so the produce and the manufactures of its dominions, posessions, Colonies

1. Kr. Balfour to Sir F. Lasoelles, August BI, 1898, B.D., I, 73, Enclosure Ho. 91. 
and Protectorates, shall, in such portions of the territorios comprised in the prosent Convention as may fall to the other contracting Party, participate in all the prerogatires, exemptions and privileges with regard to trade, commeree, taxation and navigation which are there enjoyed by the subjects of, and natives of the Protectorates of, the other Contracting Party.

IV. With regard to the Vth Article of the Convention of to-day s date, which refers to private rights of Britioh or Gorman subjects in the Provinoes of Mozambique, Angola, and the Portuguese Timor, it is well understood botween the two Gorernments that this Article applies, among others, to the so-called Katembe Concession, and, fur ther, that the Government of Great Britaln will adopt a friondly attitude in respect to the confirmation of this concession by the Portuguese Government in case such a confirmation should be applied for.

v. The present Convention shall be ratified, and the ratifioations theroof shall be orchanged a soon as possiblo. The Corrention hell oome into forco immodiately after the exohango of ratifications.

In witnese whereof the Undersignod, duly authorlsed, have signed the same, and have affized thereto their seals.

Done in duplicate, at Iondon, the 30th day of Anguest, 1898.

$\begin{array}{ll}\text { (I.S.) ARTHUR JAMES BALTOUR } & \text { (I.S.) P. HATZFHLDT }\end{array}$ 


\title{
APPENDIX C
}

\author{
Secret Hote, Signed by Count Hatzfeldt \\ and A.J. Balfour 1
}

Bnelosure in 110.92

Secret Note

\begin{abstract}
In order to make clear the intention of the two Conrentions of this day's date, it is further unders to od between the two Governments a follows:

In the ovent of one of the two Government:
\end{abstract} obtaining from the Portuguese Government before the contingeney contemplated in Artiole III of the Seoret Convention a cession of territory, or the concession of special privileges not of on occasional oharacter, in those portions of the Portuguese Provinces of Mozambique, Angola, or Timor, the customa revenues of which have been assigned to it, it 18 woll understood between the two Governments that such cessions of territory, or concessions of privileges, shall not become operatire antil analogous grants as near as possible of equal value have been accorded to the other Government in those portions of the prorinoes, the customs revenues of which have been assigned to it by the present arrangement.

In case e1ther Government applies for special privileges of an occasional character, it shall immediately inform the other Government, and if these privileges are granted, and if the other Government should desire it, shall use its influence to obtein for the other Government similar special privileges of an occasional character and of oqual value.

And whereas, owing to the imperfect surveys which alone are at present avallable, the IInd Article of the Convention of this day's date may not

1. This note explaine the position of Great Britain and Germany in certain eventralities in regard to the Portuguese possessions in Africe, south of the Equator, and the Portuguese portion of the Island of Timor. Mr. Balfour to Sir F. Lascelles, August 31, 1898, B.D., I, 74-5, Enolosure No. 92 . 
exactly carry out the intentions of the Contracting Parties, it is understood between them that in any case the port and town of Ambriz shall be included in the security assigned to Germany.

In case, therefore, that the port and town of Ambriz should be found to 11 to the south of the 8 th parallel of south latitude, the line of demaroation shall start from a point on the coast 5 Rnglish miles south of the port of Ambriz, and be continued thonoe due east until it reachos the 16th degree of longitude east of Greenwioh.

From the intersection of the line, which may be determined as the line of demarcation, with the l6th degree of longitude aforesald, the ine shall, if necessary, be extended along that degree of long1tade so far south of the 9 th parallel of south latitude as will secure to Germany a strip of territory not less than a geographical degree in wiath between the southern extremity of the Congo Free State in the region of Iunda and the northerm frontier of the portion of Angola of whioh the custome revenues are assigned to Groat Britain.

Done in Duplicate, at Iondon, the 30th day of August, 1898.

(I.S.) ARTHUR J AMES BALFOUR

(I.S.) P. HATZFFHDT 


\section{APPENDIX D}

\section{Anglo-Portugue se secret Dpolaration Ooto ber 14, $1899^{1}$}

\section{Secret}

The Government of Her Majesty the Queen of the United Kingdom of Great Britain and Ireland, Empress of India, and the Government of Hi Most Faithel Majesty the King of Portugal and the Algarves, considering as of full force and effect the anolent treatios of allianoe, amity and guarantee which subsist between the two Crowns, spocifically oonfirm on this ocossion Artiole I of the Treaty of the 29th January, 1642, whloh runs as fol lows:

"It is conoluded and accorded that there 1s, and shall be for ever, a good trae and firm peace and amity between the most renowned Kings, Charles King of Great Britain and John the Fourth King of Portugal, their heirs and sucoessors, and their Kingdoms, Countries, Dominions, I and s, People, Iiegemen, Vassale and Subjects whomsoever, present and to come, of whatsoever condition, dignity or degree they may be, as well by land $a s$ by $s e \theta$ and fresh waters, so as the said Vassals and Subjects are each of them to favour the other and to use one another with friendly offices and true affoction, and that neither of the said most renowned Kings, their holrs and successors, by himself or by any other, ohall do or attempt anything against each other, or their Kingdome, by land or by sea, nor shall consent nor adhere unto any war, counsel, or Treaty, in prejudice of the other."

They equally confirm the final Article of the Treaty of the 23rd June, 1661, of which the first part runs as follows:

"Over and above all and singular agreed and concluded in the Treaty of Marriage between the Most Serene and Most Powerful Charles, the 
Second of that name, King of Great Britain and the Most Virtuous and Serene Lady Catherine, Infanta of Portugal, it is by the Secret Articlo conoluded and acoorded, that His Majesty of Great Britain, in regard of the great advantages and increase of dominion he hath purchased by the abore-mentioned Treaty of Marriage shall promise and oblige himself, as by this present Article he doth, to defond and protect all conquests or colonies belonging to the Crown of portugal against all his onemies, as well future as present."

The Government of His Most Faithful Majesty undertakes not to permit, after the doclaration of war between Great Britain and the South African Republic, or during continuance of the war, the importation and passage of arms, and of munitions of war destined for the latter.

The Government of His Most Faithful Majesty will not proclaim neutrality in the war between Great Britain and the South African Republia.

Done in duplicate, at Iondon, this 14th day of October, 1899 .

$$
\begin{array}{ll}
\text { (I.S.) SAIISBURY } \\
\text { (I.S.) IUIZ DE SOVERAL }
\end{array}
$$




\title{
APPBNDIX E
}

\section{Enclosure in No. 341}

\author{
Draft Convention 1 \\ on Portuguese Colonies \\ Initialled by Grey and Hatzfeldt \\ October 20, 1913
}

(Confidential)

In viow of the possibility that Portugal may require financial as sistance from aome forelgn Power or Powers, and in order to obviate the international complieations which woh a condition of thinge may produce, and to preserve her integrity and independence, and in $\nabla 10$ of the special interests of Great Britain and Germang in their respectivo possessi ons and protectorates in East and Fest Africa contiguous to certain Portuguese dominions, the undersigned, duly authorised by their respective Sovereigns, have agreed as follows:

1. (1) Thenerer oither the British or the German Government is of opinion that it is expedient to accede to a request for an adrance of money to portugal on the security of the custome revenues or other revenues of Mozambique or Angola, it shall communicate the fact to the other Government, and the other Government sholl have the right to advance a part of the total sum required.

(2) In the erent of the other Goverment 1gnifying its intention to exercise this right, the two Governments shall consult as to the terms of these two loans, 2 and these loans shall be lssued on the security of the custome revenues of Mozambique and Angola as near' as possible the same proportion to each other as the amounts of the customs revenues respectively assigned a their security.

1913, B.D., X, Pt. II, No. 341.

2. The final text initialled on October 20, 1913, has here "the two loans."

3. The final text initialled on October 20,1913 , has here "nearly." 
(3) The loans shall be issued on terms as favourable to Portugal as the condition of the money market and the security of the loans permit, and shall in other respoots bo sub ject as nearl as possible to similar conditions.

2. In the contingency contemplated in the precoding article the cus tom revenues of that portion of the province of Mozambique lying south of a line startIng from the mouth of the River I ukugu, ranning thence al ong that river to its confluence with the River Ingera, thence along that river to its source, thence along the meridian of that source to the 16th parallel of south latitude, and thence along that parallel to the boundary of the British protectorate of ilyassaland, as also the customs revenues of the portions of the province of Angola lying to the east of the 20th meridian of east longitud $\theta$ and south of the Kassai River, shall be as signed to the British loan; whilst the cus toms revenues of the remaining parts of the provinces of Mozambique and Angola (which latter inoludes the administrative district of the Congo, which has Its seat of government at Cabindal shall be as signed to the Germen loan.

3. In the event of lireat Britain or Germany sending delegates to take note of the collection of the revenues, which are the security for their respective loans, the Portuguese Government shall be asked to give such delegates rights of inspection only, but no right of administration, interference, or control, so long as there is no default in the payment of interest or sinking fund.

4. In case of default in the payment of the interest or sinking fund of either loan, it shall be agreed with the Portuguese Govermment that they will hand over the administration of the various custom-houses in the two provinces: those assigned for the German loan to Germany; those as signed for the British loan to Great Britain.

5. (1) In the contingency contemplated in the procoding article all rights, whether British or German, acquired in the provinces affected, before the date of 
this convention, shall be fully safeguarded, provided they are of a purely private character and do not convey either political rights, territorial furisdiction, or administrative powers.

(2) It is will be used in the future either by the British or the Germen Government to obtain fresh concessions, except in those portions of the provinces of which the customs revenues would be assigned to the ir respoctive loan under the present convention.

6. From the date of the conclusion of the present convention Great Britain will abstain from advancing any claim of whatsoever kind to the possessi on, occupation, or control of those portions of the Portaguese provinoes in which the customs revenues would under the present convention be assigned to Germany, or of the 1slands of San Thome and Principe, or to the exercise of political influence in those territorios or islands; and Germeny will in like manner abstain from advanoing any olaim of whatsoever kind to the posseasion, occupation, or control of those portions of the Portuguese provinces in which the oustoms revenues would under the present oonventi on be assigned to Great Britain, or of the Portuguese part of the 1sland of Timor, or to the exercise of political influence in those territories or in that island.

7. (1) In the event of either Government obtaining from the Portuguese Government a cession of territory, or the concession of special privileges not of an ocoasionall oharacter, in those portions of the provinces of Mozambique or Angola of which the customs revenues would be assigned to it, ouch cessions of territory or concessions of privileges shall not become operative until analogous grants as near as possible of equal value have been accorded to the other Goverment in those portions of the provinoes of which the customs revenues would be assigned to it by the present convention.

(2) In case either Government applies for special privileges of an occasional character in those portions

\footnotetext{
1. The Inal text inftiallod on ootober 20, 1913, adds here "that is, minor or temporary."

2. The finsl text initialled on 0ctober 20, 1913, has here "nearly."
} 
of the Portuguese provinces of which the customs revenues would be assigned to it under the present convention, it shall immeditely inform the other Goverament and, If these privileges are granted, and if the other Government ahould so desire, shell use its influenee to obtain for the other Government - imilar speoial privileges of an occasional character and of equal value.

8. If in any part of the provinces of Mo zambique or Angola the Iives or property of Britioh or German subjects, or the vital intereste of the adjoining British or German dominions or protectorates, are endangered by $100 a l$ disturbances or by the action of the looal authorities, and the Portuguese Government are not in a position to afford the necessery protect10z, or otherwise fail to do so, the British and German Governments, after consuiting together, and after a joint commanioation to the Portuguese Government, shall determine the nature, duration, and scope of such measures as it may be deemed necessary to take for the protection of the interests endangered.

9. If any of the Portuguese colonies in question. haring becom independent and having been recognised as such by the two high contracting parties, or if any part of such independent colony, should deciare its annexation to the dominions of one of the two contracting Powers, the other contracting Power shall, for 1 ts part, be entitled, after previously informing the first Power, to annex those portions of such colony, thus become independent, of which the oustoms revenues rould be assigned to it under the prosent compention.

10. Groat Britain and Germany, having regard to the interests of their respective possessions in East and West Africa contiguons to the Portuguese provinces of Angola and Mozambique, which would bo materially affected by the intervention of any third Power in those provinces, agreo jointiy to oppose such intervention whether by way of loan to portugal on the security of the revenues of the said provinoes, or by way of aequisition of territory by grant, cession, purohase, lease or otherwise.

11. In so far a Great Britain or Germany may hereafter influence or control the administration of Mozambique or Angola or any portion of those provinoes, it is understood that the subjects, and natives of the 
protectorates, of one contracting party, together with the ir goods and ships, and also the produoe and the manufactures of its dominione, possessions, colonies, and protectorates, shall, in such portions of the territories comprise in the present convention as may fall under the influence or control of the other contracting party, partiolpate in all the prerogatives, exemptions, and privileges with regard to trade, commerce, taxation, and navigation whioh are there enjoyed by the subjects, and natires of the protectorates, of the other contracting party.

12. The effect of the provisions of the present convention is shown generally on the annexed copy of Stanford' Map of Africa, 1911.

13. The present confention shall replace as between the contracting Powers the convention, secret convention, and secret note concluded and igned in Iondon on the 30th August, 1898, which are hereby abrogated.

14. The present convention shall be ratified and the ratifications thereof shall be exchanged as soon as possible. The convention shall come into force immediately aftex the exohenge of ratifications.

In witness whereof the undersigned, duly authorised, have signed the same, and have affixed thereto their seals.

Done in duplicate at Iondon, the day of , 19138

1. The final text initialled on october 20,1913 , omits the word "as between the contracting Powers."

2. The agreoment was never aigned. 


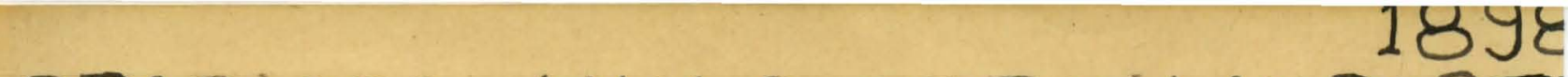

PROPOSED ANGLO-GERMAN PART

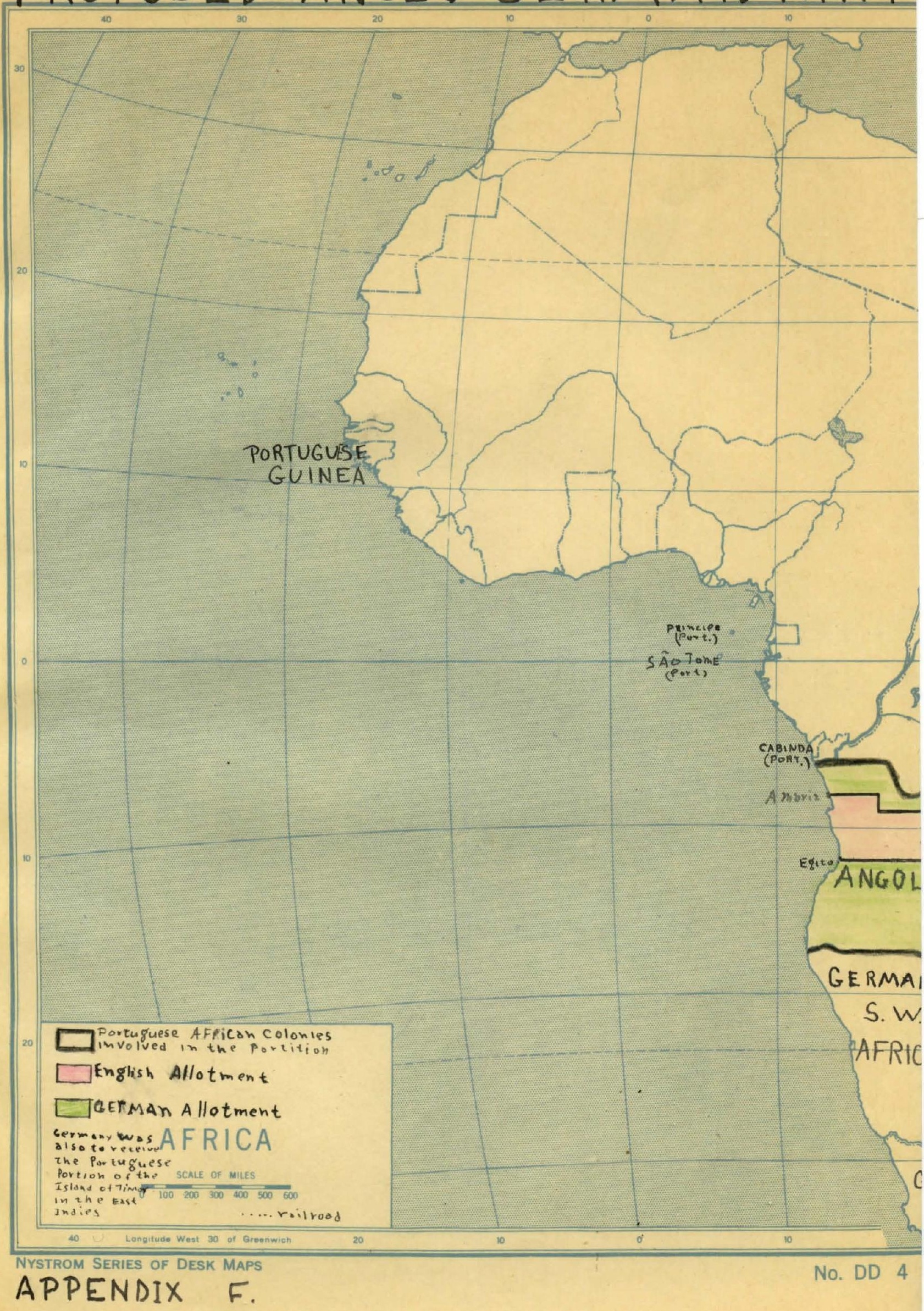




\section{3}

PROPOSED ANGLO-GERMAN PARTI

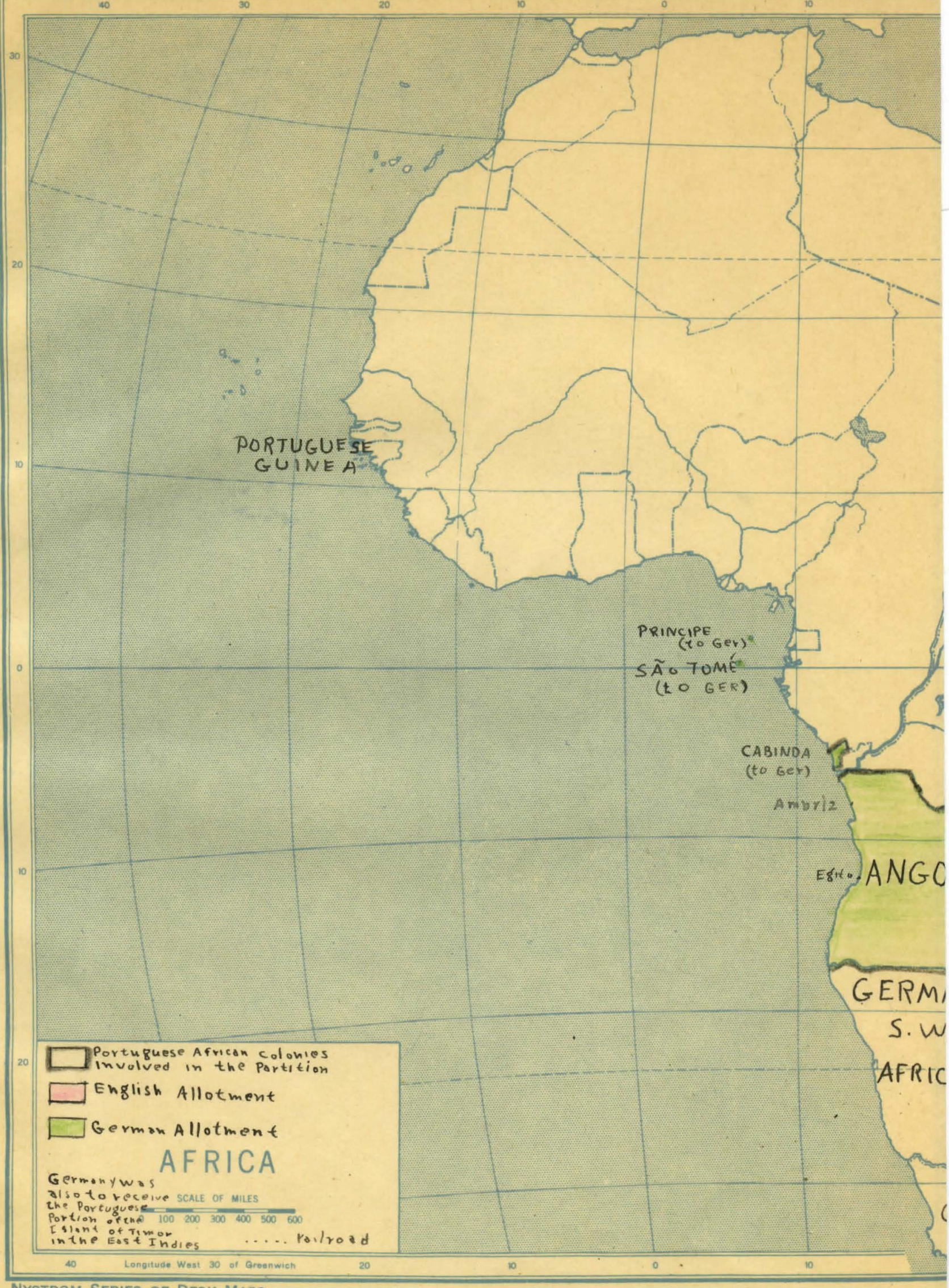




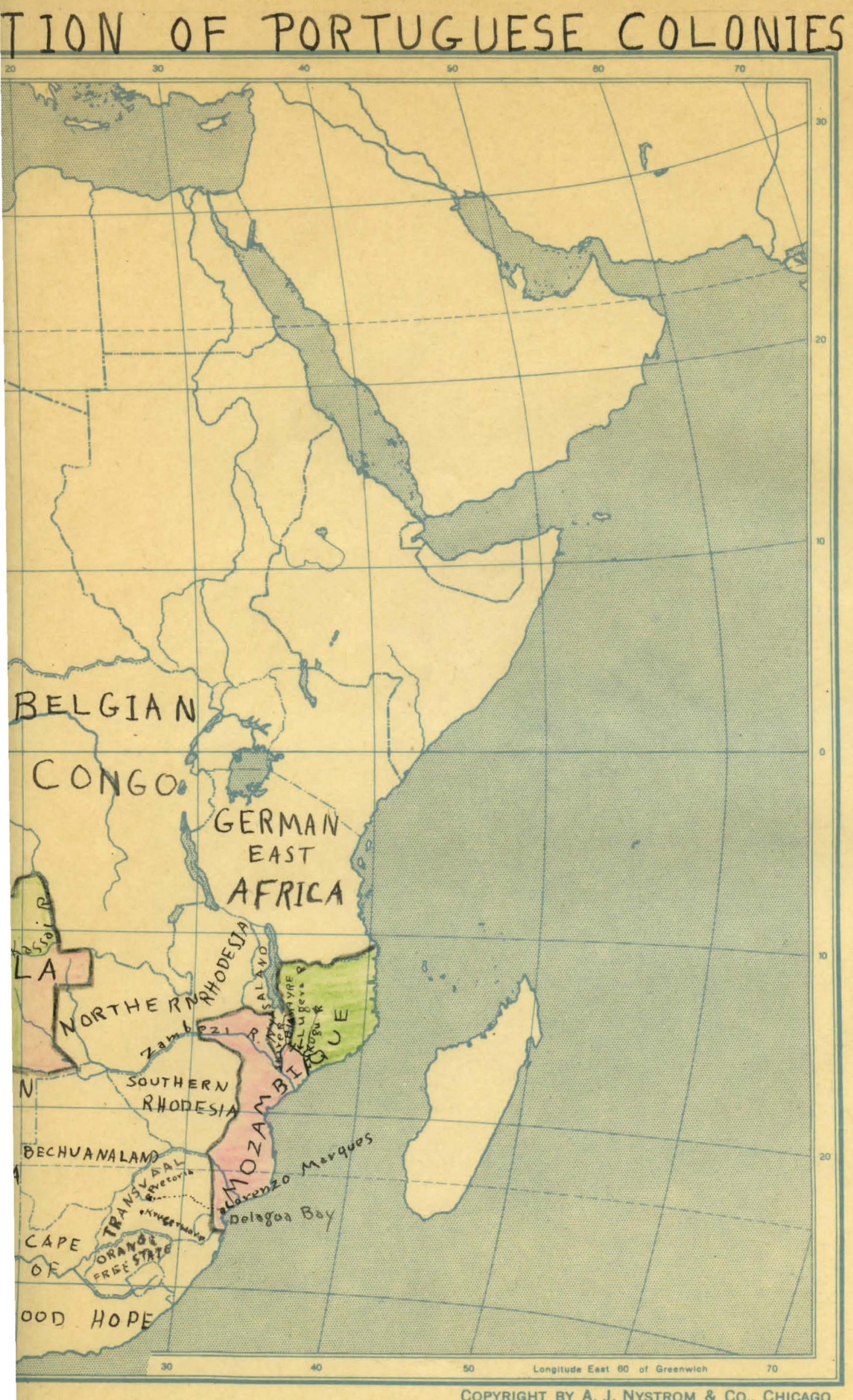

